


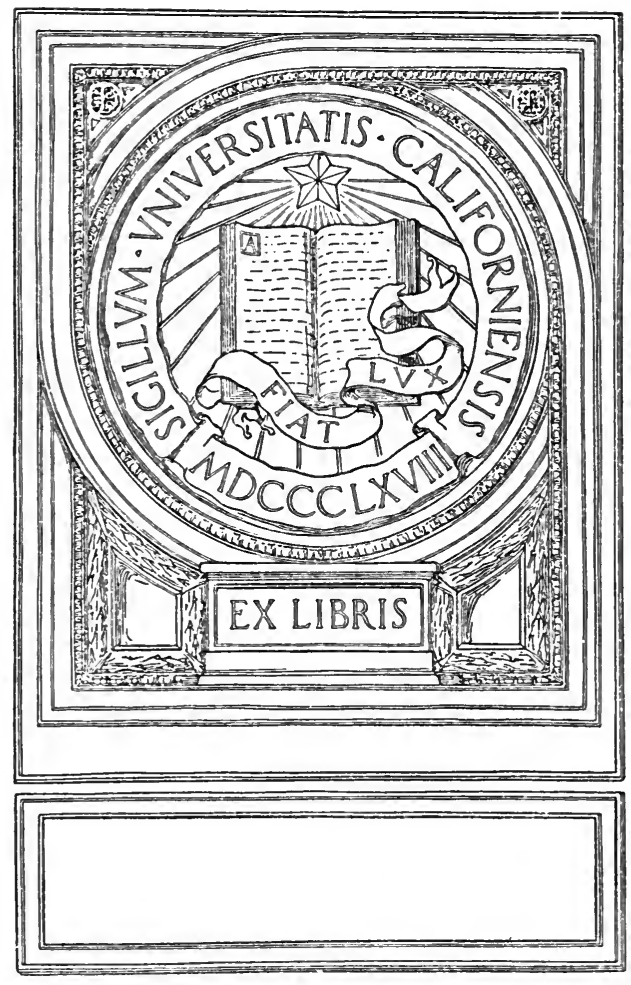




$$
\text { EB59 }
$$
x. 
Digitized by the Internet Archive in 2007 with funding from Microsoft Corporation 
Cambringe Arrbaenlogíal and Ethnologíal Beries

THE PLACE-NAMES $\mathrm{OF}$

NOTTINGHAMSHIRE 
The Cambridge Archaeological and Ethnological Series is supervised by an Editorial Committee consisting of M. R. JAMES, Litt.D., F.B.A., Provost of King's College, P. GILES, Litt.D., Master of Emmanuel College, A. C. HADDON, Sc.D., F.R.S., University Reader in Ethnology, WILLIAM RIDGEWAY, Sc.D., F.B.A., Disney Professor of Archaeology, E.J. RAPSON, M.A., Professor of Sanskrit, and W. H. R. RIVERS, M.A., F.R.S., University Lecturer in Physiology of the Senses. 


\title{
THE PLACE-NAMES
}

$\mathrm{OF}$

\section{NOTTINGHAMSHIRE}

\section{THEIR ORIGIN AND DEVELOPMENT}

\author{
by \\ HEINRICH MUTSCHMANN, \\ M.A. (Liverpool), Ph.D. (Bonn)
}

Lecturer in German and in Phonetics at the University College, Nottingham

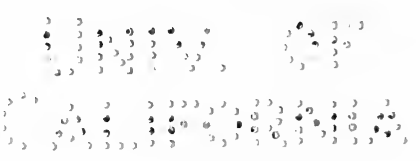

Cambridge :

at the University Press

I 9 I 3 


\section{DA670 N9M8}

\section{CAMBRIDGE UNIVERSITY PRESS}

Flondon: FETTER LANE, E.C.

C. F. CLAY, MANager

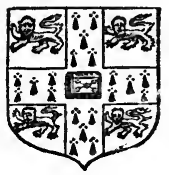

Erinburgh: IO, PRINCES STREET

Berlin: A. ASHER AND CO.

Ileipsig: F. A. BROCKHAUS

Rewo Gork: G. P. PUTNAM'S SONS

Bombay and CaIcutta: MACMILLAN AND CO., LTd.

Toronto: J. M. DENT AND SONS, LTD.

厄̧okpg: THE MARUZEN-KABUSHIKI-KAISHA

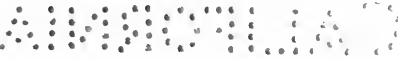




\section{PREFACE}

FOR a first introduction to the science of Names I am indebted F to the late Dr Felix Solmsen's lectures (Über Namen, besonders griechische, lateinische, deutsche), delivered in the University of Bonn, in 1905.

This present work on the Place-Names of Nottinghamshire was originally written as a thesis in the School of English Language and Philology of the University of Liverpool. The subject was suggested to me by Professor H. C. Wyld, to whose teaching and kind assistance I owe much.

The field of place-name research is a distinctly dangerous one, and it was only after long hesitation that I decided to lay this study before the public. At one time I was quite prepared to suppress the work entirely, although much time and energy had been spent on its composition. If now given to the world it is because I have been persuaded that its perusal may afford pleasure and instruction to some, and that the theories-often very bold-propounded in the book may draw valuable comments from its critics. It is also hoped that it will stimulate research in a much neglected province of Germanic philology.

It is my pleasant duty to express my sincerest thanks to all who have assisted me in the writing and printing of this book. $\mathrm{Mr}$ Robert Mellors (Author of In and about Nottinghamshire, etc.) has throughout placed his great local knowledge at my service. Dr F. J. Curtis, B.A., Ph.D., Professor of English Language and Literature in the Akademie of Frankfurt am Main, has with great kindness read through the proofs and suggested many useful emendations.

I must here also express my gratitude to $\mathrm{Mr}$ J. Potter Briscoe, the Nottingham City Librarian, for having afforded me every facility for using the volumes of early records and other important works which are in the Reference Library, and also for 
having obtained for me a number of books indispensable to a writer on philological subjects, but not usually contained in provincial libraries.

To all those by whose generous aid the issue of this book has been made possible I wish to express my grateful thanks. Contributions towards a publishing fund were received from: The Faculty of Arts of the University of Liverpool; The Nottinghamshire Society of London; His Grace the Duke of Portland; The Right Honourable the Earl Manvers; The Lord Bishop of Southwell; Sir Thomas Birkin, Bart.; H. Hampton Copnall, Esq., Clerk of the Peace ; Principal Heaton; Jesse Hind, Esq., J.P.; W. H. Mason, Esq., J.P. ; Colonel Mellish, D.L.; Robert Mellors, Esq.; Major Robertson, J.P.

H. M.

Weimar, August 1913. 


\section{TABLE OF CONTENTS}

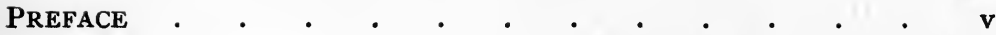

TABLE of Contents . . . . . . . . . . . . vii

LIST OF ABBREVIATIONS • . . . . . . . . . . . viii

Table of Phonetic Symbols. . . . . . . . . . . i ix

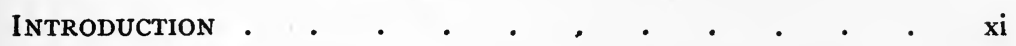

NotTinghamshire Place-NAMES (IN AlPhabetical ORDER) • I

Phonology of the Notts Place-Names

I. Vowel Changes . $\quad . \quad$. $\quad . \quad$. $\quad . \quad$. 159

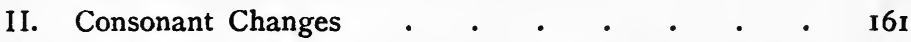

Words other than Personal Names in the Notts PlaceNAMES

I. Words of Anglo-Saxon Origin . . . . . $\quad{ }^{164}$

II. Words of Scandinavian Origin . . . . $\quad$ - 168

III. Words of French and Latin Origin . . . . 169

APPENDIX : Some of the More Frequent Suffixes Explained • 169

The Principal Personal Names in the Notts Place-Names

I. Anglo-Saxon and Norse Personal Names . . . 173

II. Norman-French Personal Names . • . . $\quad{ }_{176}$

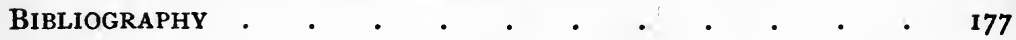




\section{LIST OF ABBREVIATIONS}

N.B. For Abbreviations of Sources of Early Forms see Bibliography, Part I.

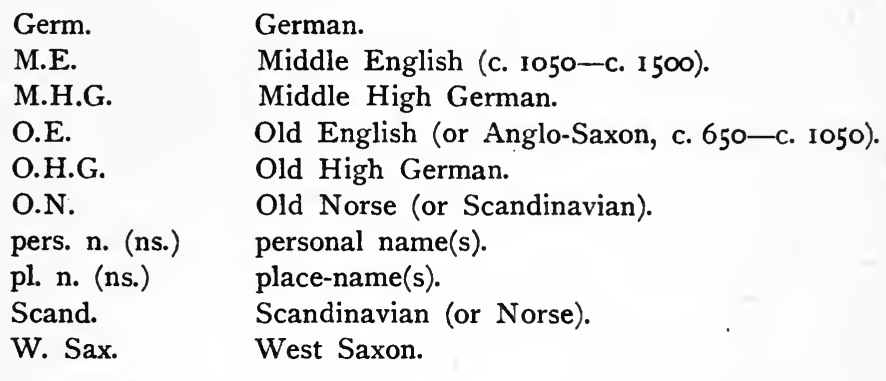
Dial. Dict. Wright's Dialect Dictionary.
Dial. Gramm. Wright's Dialect Grammar.
N.E.D. New English (or Oxford) Dictionary.
Vigf. Vigfusson's Icelandic Dictionary.
** For full titles of the above and other Works of Reference see Bibliography.

An asterisk (*) before a word denotes a reconstructed or hypothetical form.

A query (?) denotes a doubtful etymology.

$>$...develops into....

$<$...is derived from.... 


\section{TABLE OF PHONETIC SYMBOLS}

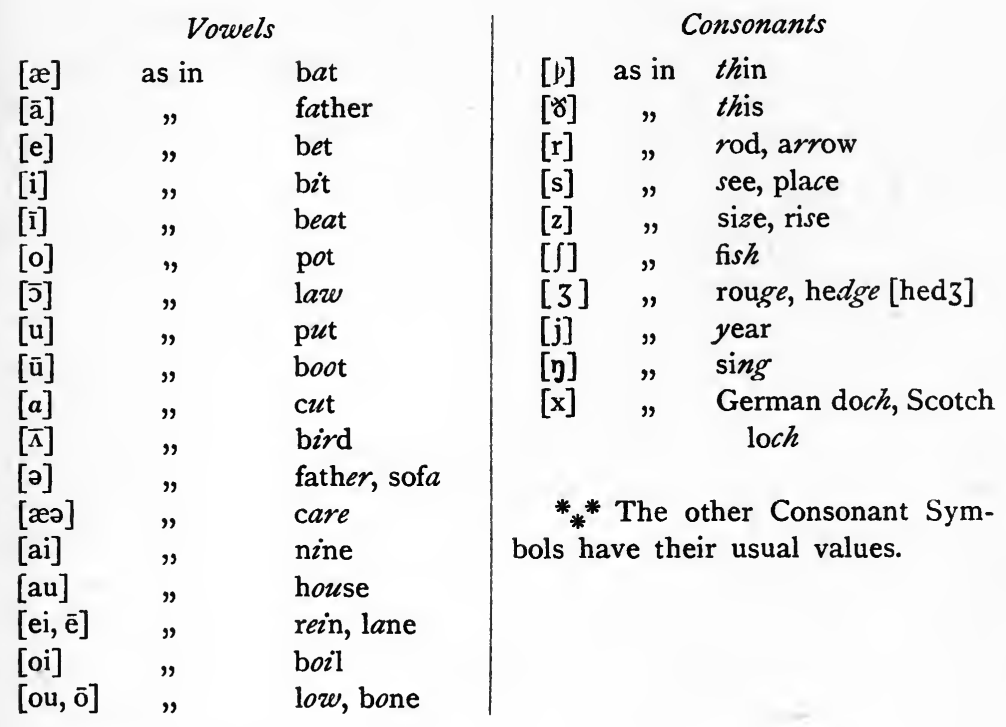

Stress is marked thus ['כ̄].

Phonetic representations are usually placed within square brackets.

NOTE. The phonetic forms in square brackets after the names represent the local pronunciation. In most cases a polite pronunciation closely following the spelling exists, but is not specially recorded.

Transliterations enclosed in round brackets are taken from Hope's Glossary of Dialectal Place Nomenclature, 1883. 



\section{INTRODUCTION}

BRITISH Place-Names that have an obvious meaning such as Clifton, Red Hill, Horsepool, Nezwthorpe, are very few in number, and often of but recent origin. The majority seem at first sight mere arbitrary conglomerations of sounds having no perceptible relation to the localities with which they are associated. The names Nottingham, Trent, Cropwell, etc., are in everyday use; we know the places or objects to which they apply-but we do not know why there should be any connection between them. That such must have existed when the name was first given, or rather sprang into being, will hardly be disputed. The exact nature of this connection, or, in other words, the origin and meaning of the place-name, has at all times been a favourite subject of speculation, both to the learned and the ignorant alike. The attempts of the latter class, besides producing popular etymologies, have given rise to many quaint tales and stories, invented to endow with some significance an otherwise obscure name. Thus Mansfield is said to derive its name from a count of Mansfeld, in Saxony, who is supposed to have taken part in a tournament held in the famous field near by. Similarly, Styrrup, in the same district, is held by some to be "in some way or other connected with the training of horses" for purposes of the noble art of tourneying; whereas Blyth has the reputation of being named after "the mirth and good-fellowship of the inhabitants therein." Many more such curious items might be adduced if this were the proper place for their recital. We will, however, take leave of this fascinating subject with the mere mention of that ingenious divine who, "by the slightest change in orthography," made most of the village names round Nottingham have some reference to Baal and to high places.

Much more dangerous than these obviously wrong etymologies are those advanced, often with a great show of learning, by devoted amateurs, chiefly antiquarians or geographers. A common 
feature of writers of this class is that they imagine it their chief duty to explain not so much the nature and meaning of the name, as the reason why it was given to the locality. They approach the question with the particular bias of their favourite subject, and very often with preconceived ideas. Thus one will be alert to discover references to prehistoric settlements; another is bent on finding the natural features of the neighbourhood embodied in the nomenclature of the district; a third will connect the names of places with persons or events belonging to national and local history.

\section{Composition of Place-Names.}

It is a well-known characteristic of the majority of Teutonic personal and local names that they consist of two elements or themes. English place-names of one theme only were very few from the beginning, and popular etymology has sirice been at work changing the appearance of these few so as to make them conform to the majority. Here belong various Old English names, originally in the dative case, whose ending $-\iota m$ came to be written -ham, as if it represented O.E. häm, "home," as e.g. in Askham, Averham, Kelham, Laneham. Lound, Clumber, Coates, are also examples of uncompounded place-names.

Bi-thematic names almost invariably contain as their second element a noun of a descriptive character, denoting either a natural object, such as wood, field, stone, cliff; or a work of man, such as ton ("town"), worth, thorpe, borough. The first element, which has also been described as the adjectival theme, is of a different, a qualifying character. It may consist of an adjective proper, as in Radcliffe ("red"), Cuckney ("quick"); of a common noun used adjectivally, as in Flintham, Stapleford. But by far the most frequent mode of forming English, and for that matter, Teutonic place-names is by prefixing a personal name descriptive of the original settler, the owner, inhabitant, or other person connected with the locality. Very often the personal name involved does not appear in the singular, but in the plural of a collective patronymic ending in -ing, and meaning "the family, or descendants of so and so." The persons whose names are thus perpetuated are almost without exception unknown to 
history; no doubt they were often but simple peasants, cottagers, or even serfs. Place-names of this kind, therefore, fail to appeal to the imagination; they are sadly lacking in romance. The only good that can be said in their favour is that they have served, and are still serving, an excellent purpose in practical life, and that they provide with amusement the philologist whose business and delight it is to explain the changes which they have undergone in their passage through the centuries.

\section{Place-Name Research a Linguistic Problem.}

Place-names are words in the first instance, and as such their elucidation is primarily a linguistic problem. This will become clear on examining the causes that make place-names unintelligible. These causes are manifold, but the most important may be tabulated as follows:

(I) Certain elements contained and preserved in placenames have disappeared from everyday language; e.g. -by; -bourne; and the majority of old personal names.

(2) Certain elements have, in their independent form, assumed a new meaning; e.g. -ton (=town); well; beast (in Bestwood).

(3) Old genuine dialect words (or forms) have become obsolete, because ousted and superseded by forms of the literary language; e.g. cuck (=quick) in Cuckney.

(4) The place-name may be derived from a foreign tongue ; e.g. Trent, Doverbeck.

(5) The elements contained in a place-name follow developments different from those of the independent words. In a composite name they are more subject to the simplifying processes of shortening and assimilation. For examples of excessive shortening see Broxtow, Bassetlaw, Caunton. See also special chapter on Assimilation (Phonology, § I3).

(6) Popular etymology often obscures the original meaning of place-names. See Arnold, Askham, Birkland, Cropwell, Eastwood, Hempshill, Kingston, Martin, Oldcoates, etc.

(7) The influence of the spelling interferes with the natural development of place-names. The prevailing and inevitable tendency is to pronounce the names "as they are spelt," although 
the written form is very often no sure guide to the etymology. Thus a number of place-names whose first element was a Norse personal name containing the adjectival theme Thor-, are now pronounced with initial $t$, because $t$ was written by AngloNorman scribes for the sound of th.

\section{Methods of Investigation.}

From the foregoing exposition it is clearly evident that the investigator of place-names cannot base his theories on the modern forms which are the result of the change and wear of centuries. It is necessary to go back to the oldest available spellings, which have to be laboriously collected from a variety of documents printed, for the most part, in the invaluable series of official government publications. Owing to the County's position away from the centre of West Saxon rule, the number of Old English charters relating to Nottinghamshire is exceedingly small. The few documents of this description to be found in Kemble's Codex Diplomaticus, and Birch's Cartularium Saxonicum, are, moreover, very unreliable, and probably late copies or forgeries. The County is but poorly represented in Doomsday $B o o k$, and the number of local records of a civil and monastic nature, which are available in published form is lamentably small. This is the more to be regretted as local documents very often contain much more useful spellings than the national ones, which were, particularly in the reigns immediately following the Conquest, often drawn up by Norman-French scribes or by other persons unacquainted with the localities and the speech habits of the people.

Having collected as many early spellings as possible, the investigator proceeds to arrange them in chronological order. Thus the changes that a name has undergone are illustrated, though in a great many cases philological explanations of a highly technical nature are necessary in order to reconcile the various spellings with each other. Often it will be found necessary to distinguish various Types, each of which should be treated separately. These owe their existence to a variety of causes. A place-name is sometimes found both in the nominative and dative cases; substitution of elements occasionally occurs 
as the result of popular etymology; the first element, if a personal name, may have the genitival ending or not; one type may represent the local pronunciation as distinct from the official spelling, etc., etc. These are a few examples of the causes leading to the development of different types.

Each of these types has its own history; but only one can be represented by any given modern form. As a rule, all but one are gradually eliminated; yet it sometimes happens that a local or old-fashioned pronunciation is descended from a different type from the one which survives in the modern spelling.

In this connection, particular attention should be paid to possible errors committed by the Norman-French scribes of Doomsday Book and other feudal records. Many of the genuine English sounds were unfamiliar to them, and they often blundered in the rendering of native English words, or modified the pronunciation, and consequently, the spelling of the place-names according to their own French speech habits (see special chapters on Norman Influence, Phonology, $\$ 1$ 1, 22).

It is, therefore, the philologist on whom devolves the duty of elucidating the meaning and the history of place-names. In his task he should be aided by the local topographer and antiquarian; but as there is, unfortunately, no organisation to ensure the co-operation of all classes of investigators concerned, the philologist will occasionally go wrong for want of local knowledge. Thus, for instance, the local pronunciation of place-names is often as valuable as a very old and genuine spelling; and yet it is nothing short of impossible for the individual and isolated worker to collect a complete and reliable list of such pronunciations.

There is one further aspect of place-name research to which attention must be called. The investigator should not confine himself to the contemplation of the names of one single district. He should go further afield, and study as far as possible the principles and peculiarities of English, and also Teutonic nomenclature generally. Outside England, those countries from which the majority of settlers were drawn, Low Germany, and, in a slightly less degree, Scandinavia, will supply useful analogies. 
Some Characteristics of Nottinghamshire Place-Names.

A cursory examination of the main part of this book will convince the reader that the bulk of the place-names of Nottinghamshire are of Anglo-Saxon origin. A considerable number of Scandinavian elements are present; and if these were marked in a distinctive colour on a map, very interesting conclusions might be drawn from the nature of their distribution. I believe they would show that the Scandinavian invasion, which ultimately led to the settlement of the Norsemen in large numbers, was of a comparatively peaceful nature. The Northern newcomers apparently did not try to oust the original occupants of the land, but were satisfied to settle in the marshy, sandy, unattractive regions left vacant by the Anglo-Saxons.

The British and Roman settlements, which no doubt existed anterior to the advent of the Teutonic invaders, seem to have completely lost their original names. Only a few indications of Roman occupation are left. Brough and Littleborough refer to pre-Anglo-Saxon structures of Roman origin, whereas Celtic elements survive in the river-names ${ }^{1}$ Trent, Doverbeck, Devon, and Dean. Some Celtic word may also be contained in the first part of Mansfield.

Norman-French influence is apparent more in the modification of native names than in the creation of new ones. Perlethorpe, containing a French personal name as first element, is a rare example of a post-Conquest formation on the old principle of Teutonic name composition. Beauvale and Belvoir, marked by a touch of the romantic spirit appertaining to the age of chivalry, and thus notably distinguished from the bulk of commonplace Germanic names, are instances of completely NormanFrench formations. On the other hand, distinctive additions to older place-names are frequently of Norman-French origin. They usually take the form of the new feudal owner's name which is tacked on to the older native name of the place, as in Cropwell Butler, Holme Pierrepont, etc.

1 The Rev. John Sephton, M.A., in his Handbook of Lancashire Place-Names (Liverpool, 1913), expresses the very interesting opinion that the vitality of Celtic river-names is due to religious or superstitious causes (p. 132). 


\section{NOTTINGHAMSHIRE PLACE NEAMES,}

Adbolton (in Holme-Pierrepont).

$$
\text { Type } I \text {. }
$$

I086 Alboltune, D.B.

$$
\text { Type II. }
$$

I3I6 Adbolton, Bor. Rec.

1346 Adbolton, F.A.

1571 Adbolton, Index.

"The tīn or farmstead of Ealdbeald (Type I), or Eädbeald (Type II)." Both personal names occur frequently. Interchange of prefixes is found in the pers. ns. themselves : Ealdbeald, king of Kent, appears as Eädbeald in some sources (see Onomasticon).

- Alverton [olvatn].

$$
\begin{aligned}
& \text { I086 Alvretun, Alvritun, D.B. } \\
& \left.\begin{array}{l}
\text { I } 278 \\
\text { I } 304 \\
\text { I } 316
\end{array}\right\} \text { Alverton }\left\{\begin{array}{l}
\text { H.R. } \\
\text { Index. } \\
\text { F.A. }
\end{array}\right.
\end{aligned}
$$

"The tün of Alfer," O.E. Alfherestīn; Alfer is an O.E. and M.E. short form of AElfhere (Onomasticon).

ALWOLDESTORP (not identified).

$$
\text { I086 Alwoldestorp, D.B. }
$$

"The borp of Ealdzeald."

M. 
AnNesley [ænzli].

$$
\begin{aligned}
& \text { I086 Aneslei, D.B. } \\
& \text { I240 Anyslegh, Bor. Rec. } \\
& \text { I284 Anisley, F.A. } \\
& \text { I42 I Annesley, Index. }
\end{aligned}
$$

"The leăh (lea) of Anna." Anna is an O.E. man's name. The early substitution of the strong for the weak declension is characteristic of the Northern and Midland dialects; Sweet, N. Engl. Gramm. $§ 989$, Sievers, $§ 276 a 5$; see Alexander, Mod. language Rẹv 7901 .

APPESTHORPE: ON HABBLESTHORPE.

$$
\text { Type } I \text {. }
$$

I 278 Harpelestorp, H.R.

I 327-77 Harplesthorp, Non. Inq.

$$
\text { Type II. }
$$

I278 Happelestorp, H.R.

1316 Apullesthorp, F.A.

c. I $500 \quad\left\{\begin{array}{l}\text { Apulthorp } \\ \text { Habylthorp }\end{array}\right\}$ Inq. P.M. c. I 500.

"The porp of *Harpel or *Arpel." The $r$ of Type I was lost through either assimilation or dissimilation,

$$
r p>p p \text {, or } r-l-r>[]-l-r \text {. }
$$

After this change the name became connected with apple. I cannot trace the pers. n. $(H)$ arpel in other English sources. It is, however, found in continental records. It appears to be the diminutive of Arpus, which is the name of a German chief mentioned by Tacitus, Ann. II, 7. See Much, Zeitschrift für deutsches Altertum, 35, 365, Grimm, Geschichte der deutschen Sprache, 580. The pl. n. Erpelingalanda is recorded by Förstemann, $\mathrm{II}^{2}$.

ARNOLD.

I086 Ernehale, D.B.

I 57 Ric. de Erneshala, P.R.

I22 I Arnehale, Bor. Rec.

1284 Arnale, F.A. 
1272-1307 Arnehal, Index.

I 316 Arnall, F.A.

1346 Arnale, F.A.

- $1428\left\{\begin{array}{l}\text { Arnewall } \\ \text { Arnal }\end{array}\right\}$ F.A.

c. I $500\left\{\begin{array}{l}\text { Arnall } \\ \text { Arnell }\end{array}\right\}$ Inq. P.M. c. I 500.

"The healh of Earne." Although the genitival $s$ is encountered but once, the first element can hardly represent the O.E. earn, "eagle." The final $d$ is excrescent ; similar cases of the development of $d$ are found in various other words both in the dialects and in literary speech; see Wright, Dial. Gramm. $\S 306$; Horn, Neuengl. Gramm. $§$ I 88 .

AsKHAM.

$$
\begin{aligned}
& \text { I086 Ascam, D.B. } \\
& \text { I } 278 \text { Ascam, H.R. }
\end{aligned}
$$

O.E. at escum, "at the ash-trees," a regular dative plural. The modern spelling is due to popular etymology: the ending ham in the modern form of this name has nothing to do with home.

ASLOCKTON or AsLaCTON.

$$
1086\left\{\begin{array}{l}
\text { Aslachetone } \\
\text { Haslachestone }
\end{array}\right\} \text { D.B. }
$$

I 302 Aslacton, F.A.

"The tün of Aslac." The pers. n. is of Scandinavian origin ; see Björkman.

Attenborough.
$\left.\begin{array}{ll}\text { c. } 1200 & \text { Adigburc } \\ \text { c. } 1240 & \text { Hadinbur }\end{array}\right\}$ Woll. MSS.
1275 Adinburks, Bor. Rec.
I291 Addingburg, Tax. Eccl.
1327-77 Adyngburgh, Non. Inq.
c. 1500 Addyngborough, Inq. P.M. c. I 500.

Either " the burh of the Eädings or of Eadda." The change from $d$ to $t$ must be quite recent, and is perhaps due to dissimilation. Similar changes in pers. names are discussed by Bardsley, Dict. of Engl. and Welsh Surnames, p. I9. 
Averham [æərəm] (Airham, Hope).

Type I.

I086 Aigrun, D.B.

c. 1200 Egrum, Index.

1278 Egrom, H.R.

129 I Egrum, Tax. Eccl.

1302 Aghram, F.A.

Type II.

1316 Averam, F.A.

1327-77 Averham, Inq. Non.

I637 $\left\{\begin{array}{l}\text { Averham (or Aram), Camden, p. } 549 . \\ \text { Havorham, Map in Camden. }\end{array}\right.$

I680 Averham, Index.

\section{Type III.}

I637 Aram, Camden, p. 549.

** c. I600 (?)...Averham, auntiently called Egrum but now comonlie called Aram...MS. BM. Titus A. xxiv. fol. I 30 b.

I take this name to represent O.E. (Mercian) at $\overline{\boldsymbol{e}} \partial \mathrm{rum}$, "at the waters, streams"; it would thus correspond to the Latin ad aquas. The exact meaning of O.E. (W. Saxon) $\bar{e} d r e$, Anglian (h)épir, èpre is "a channel for liquids, an artery, vein, fountain, river," Bosworth-Toller; the cognate German word Ader has the same meaning. The following quotation from White's Directory ( 1853 ) will explain the origin of the name: "The large island formed by the two branches of the Trent navigation opposite to Newark, is in the manor of Averham, or Aram..." (p. 460).

I have not yet succeeded in finding another instance of the occurrence of O.E. $\bar{e} d r e$ in pl. names. There are, however, a few continental names which contain its O.H.G. cognate. Mod. Germ. Brunnadern near Bondorf in Baden goes back to an O.H.G. Brunnaderon, a dat. plural; see Förstemann, II ${ }^{2}$, IO. According to Graff, Althochdeutscher Sprachschatz, I, I 57, brunadara is used by Notker in his translation of the Psalms to render the Latin manationes aquarum. The same element may be contained in the Hessian river-name Itterbach, Sturmfels, Ortsnamen Hessens, p. 4I. 
The interpretation of the various spellings of this name is not without its difficulties. I shall now endeavour to reconcile the three types with my assumption.-Type I: In AngloFrench records the open $g$ sound is frequently substituted for the English $\delta$; see Zachrisson, pp. IOI, II7; cp. the various spellings of "Leicestershire, Worcester(shire)" in different MSS. of Bede, as Lepecastrescire, Lagreceasterscire; Wiðreceasterscir, Wigraceaster, Miller, p. 46.-Type II : On the other hand, intervocalic $\delta$ often developed into $v$ in the English dialects which accounts for the second collection of forms; see Horn, Hist. Neuengl. Grammat. § I97; Wright, Dialect of Windhill, p. 9I : "Fifty years ago, $f$ for $p$ and $v$ for $t$ were quite general."-Type III : The pronunciation is [æərəm], with the regular loss of $\forall$ or $v$ before $r$ in a medial position; Horn, l.c. $§ 169$.

The development of the various forms may be tabulated as follows :

\title{
O.E. (at) $\bar{a} \partial$ rum.
}

$>$ Egrum in Anglo-French spelling;

$>$ Averum in the local dialect;

$>$ Arum in subsequent local development. The modern spelling in -ham is due to confusion with the frequent termination O.E. $-h \bar{a} m$.

N.B. Isaac Taylor's assumption (Words and Places, ch. XI) that Averham is derived from the dat. pl. of O.E. hearg, "a heathen temple," is untenable.

Awkley or Aukley.

\author{
I278 Alkelaye, H.R. \\ I3I6 Alkeleye, F.A. \\ c. I 500 Aulkeley, Inq. P.M. c. I500.
}

"The lea h of a man called Ealca, or of Ealce," a mythological person, or deity. In O.E. the pers. name Alca occurs once; it most probably represents a short form of one of the numerous "full-names" beginning with Ealh-, Ealc-; cf. also Ealac, Alac, Onomasticon, and Alako, Förstemann, I.

As to the second suggestion it cannot be denied that we find traces of a mythological person of the name of Ealce etc.; see 
Middendorf, s.v. On Low German territory, in the neighbourhood of Osnabrück, the geographical names Alke Krug and Alk Pool are found close to an ancient heathen place of worship (Mitteilungen des Vereins für Geschichte und Landeskunde von Osnabrück, XIII, I 886 , pp. 263 sqq.). The same deity or deities seem to be mentioned by Tacitus in the Germania, c. 43: "Apud Naharvalos antiquae religionis lucus ostenditur. praesidet sacerdos muliebri ornatu, sed deos interpretatione Romana Castorem Pollucemque memorant. ea vis numini, nomen Alcis (var. Alces vel $A l c i)$. nulla simulacra, nullum peregrinae superstitionis vestigium; ut fratres tamen, ut iuvenes venerantur." As commentators fail to give a satisfactory explanation of this singular passage, I thought it worth while to quote it in connection with the pl. n. under discussion, hoping that further inquiry will either strengthen or disprove the theory advanced. It is highly interesting to note that these Alces were worshipped in a "lucus," which word is closely related to the O.E. lea h (see List of Elements, s.v.). The Roman interpretation is not to be implicitly trusted.

The following pl. ns. seem to contain the same first element as Awkley:

Alkenthyt, Alkentheyt Hill, Bor. Rec. I, p. 375.

Alkenthweyt, ib. p. 39I.

Alchenfluh, in Switzerland (?); Fluh, O.H.G. Aluoh, means "Felswand, Felsabsturz."

Awsworth.

I086 Eldesworde, D.B.

I 295 Aldesword, Woll. MSS.

$\left.\begin{array}{ll}\text { I } 302 & \text { Aldisword } \\ \text { I } 316 & \text { Aldesworthe }\end{array}\right\}$ F.A.

"The weorp or homestead, farm of Ealda." The O.E. name Ealda is of frequent occurrence. It either means "the old one," or more likely is a short form of one of the numerous compound names beginning with Eald-, as Ealdhelm, -here, -weald. The appearance of an $-s$ in an originally weak noun is by no means without parallel; see Annesley. 


\section{BABBINGTON.}

Owing to the absence of early forms, it is impossible to explain this name accurately. The first element is no doubt the O.E. pers. n. Babba, which may have appeared either in the weak gen. sing. (O.E. Babbantīn), or in the patronymic form (O.E. Babbingatiun). The latter forms the first element in the O.E. pl. n. Babbingdon (Birch, Cartul. Sax. p. 316), and also in the continental names O.H.G. Papinga, Pappingen (modern Pabing) and Papingohuson (Förstemann, II).

BABWORTH.

I086 Baburde, D.B.

I3I6 Babbeworth, F.A.

1637 Badworth, Map in Camden.

"Babba's weorb or homestead." Babba is an O.E. man's name. Camden does not seem to have entertained a very high opinion of the locality.

BAGGALEE (under Greasley).

This may be "Bagga's lêah"; but there are no early spellings to support this or any other view. The place is popularly known as Beggarlee; can this be the correct etymology? There is a Beggar's Bush in Staffordshire, see Duignan, Place-Names of Staffordshire.

BAGTHORPE (under Selston).

"The porp of Bagga" ? There are no early forms.

BALDERTON.

$$
\left.\begin{array}{l}
\text { I086 Baldretune, D.B. } \\
\text { I 29I } \\
\text { I 3 I6 }
\end{array}\right\} \text { Baldirton }\left\{\begin{array}{l}
\text { Tax. Eccl. } \\
\text { F.A. }
\end{array}\right.
$$

"The tiin of Bealdhere"; the latter is an O.E. man's name of which five bearers are known (Onomasticon). The pl. n. has, of course, nothing to do with Baldr the Norse deity.

BARNBY (MOOR).

I086 Barnebi, D.B.

I445 Barnby Moor, Index.

I637 Barmbye on the Moor, Map in Camden. 
"The $b \bar{y} r$ or habitation of Barn." The suffix clearly shows that the place was a Danish settlement. The pers. n. Barn is recorded by Björkman. The $m$ in Camden is either due to assimilation, or represents one of the numerous mistakes of the engraver. The district round this place formerly was wild moorland which accounts for the distinctive addition. May we conclude from this fact that when the Danes arrived in this district, they found the best part of the country occupied by the Saxons and had to content themselves with the less alluring portions ?

BARNBY-IN-THE-WILLOWS.

$$
\begin{aligned}
& \text { I086 Barnebi, D.B. } \\
& \text { I302 Barneby, F.A. } \\
& \text { I637 Barmby, Map in Camden. }
\end{aligned}
$$

See preceding name. The place is situated on the river Witham (q. v.) which derives its name from the numerous willows growing on its banks. The same natural phenomenon supplied this pl. n. with its distinguishing epithet.

BARNSTON.

1086 Bernestune, D.B.

$\left.\begin{array}{l}\text { I } 286 \\ \text { I } 302\end{array}\right\}$ Berneston $\left\{\begin{array}{l}\text { Index. } \\ \text { F.A. }\end{array}\right.$

I 347 Barnstone, Index.

I637 Burnston, Map in Camden.

"The tün of Beorn." The pers. n. Beorn is found both in O.E. and in Scandinavian. In the latter language it was particularly frequent; see Björkman.

Camden's spelling represents a different development of the M.E. er; this combination either changed into ar, or remained unaltered. In the latter case, it coincided with ir and $u r$ in pronunciation during the $\mathrm{I} 7$ th century; see Phonology, $\S 8$.

BARTON-IN-FABIS.

I086 Bartone, D.B.

I $302\left\{\begin{array}{l}\text { Berton } \\ \text { Barton }\end{array}\right\}$ F.A.

1637 Borton, Map in Camden.

The pl. n. Barton is very widely disseminated all over the country. It is usually taken to represent O.E. bere-tūn, "corn-farm, 
grange," or more literally "barley-enclosure, rick-yard"; see Lancashire Place-Names, p. 290. It is strange, however, that the D.B. form should exhibit ar instead of er; there must have existed an O.E. barlic , the ancestor of modern barley, which may have influenced bere-tün, changing the $e$ into $a$; cp. M.E. barlic, Morsbach, M.E. Gramm. $§$ I08, anm. I, 3. The regular change of er $>$ ar did not take place till the first Modern English period; Sweet, N.E. Gramm. § 845 .

The $o$ in Camden's form is due to the rounding influence of the initial $b$; cp. Borwick ${ }^{*}$ Barwick, Lancashire Place-Names, p. 74 .

In the middle ages, distinguishing additions to pl. ns. were often translated into Latin, the language of the documents, as here in Fabis; see Zachrisson, Latin Influence etc. p. 74. The Leicestershire Barton-in-the-Beans exhibits the same addition in the native idiom.

BASFORD [beisfəd] (Bāysfud, Hope).

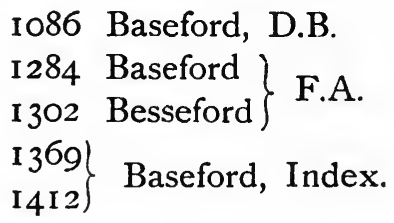

"The ford of Bass or Bassa, the ford near which Bassa lived." The $s$, being voiceless in the modern pronunciation, must represent O.E. ss. As the vowel was long in M.E., the lengthening cannot be due to its standing in an open syllable. We are, therefore, forced to assume that a lengthening of $a$ (or $a$ ) took place before $s(s)$ in early M.E., similar to that of $a$ before $s, p, f$ in the I \&th century (Sweet, N.E. Grammar, $\S 844$; Horn, Histor. Neuengl. Gramm. $\S 47$, dates this change much earlier). The F.A.spelling of 1302 shows that by that time the lengthened sound had been considerably advanced towards the front position.

BASSETlaW (Wapentake, now a Parliamentary Division).

$$
\text { Type } I \text {. }
$$

$\begin{array}{ll}\text { I I } 55 & \text { Desetelawahdr } \\ \text { I } 89 & \text { Bersetelaw Wap. }\end{array}$ I.R.




\section{Type II.}

I086 Bernedeselawe Wapentac, D.B.

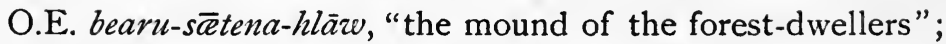
from O.E. bearu, "a wood, nemus vel lucus," sēeta, "resident, inhabitant," found in compounds only and mostly in the plural as

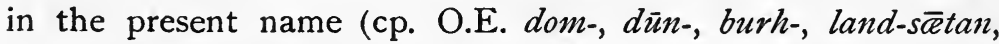
O.H.G. himil-sâzo, "inmate of heaven"). O.E. hläw may denote either "an artificial or natural mound." It was the custom of the men of a hundred and especially of a Scandinavian wapentake to assemble on a hillock which gave the name to the division. This mound was sometimes raised artificially, which is the case of the most remarkable of these lowes, Tynwald Hill in the Isle of Man. (Cp. Binghameshou Wap. in D.B.)

The initial $D$ in the P.R. of 1155 is a scribal error; the D.B. compiler probably imagined the first element of the name to be derived from the pers. n. Beornheard: the long word was too much for the French clerk.

It is interesting to note that the German Holstein has a similar origin. The name has nothing to do with Stein, "stone"; -stein is a popular corruption of -sten which is still found in the name of the Holstentor at Lübeck. The Old Saxon form of the name of the inhabitants is Holtsâti, "the dwellers in the holt or wood." The geographical name is, like the majority of German names of districts, derived from the dat. plural of the name of the inhabitants. The explanation of the name given by a mediæval writer and quoted by Förstemann (II, p. 866) might be applied to the Bearusätan with equal force: "Holcete dicti a silvis quas incolunt." White (Directory, I853, p. 577) remarks that "the ancient forest of Sherwood (q.v.) extended over a large portion of this division [i.e. Bassetlaw Hundred], nearly the whole of which, during the last century, has been enclosed and though generally a deep light sandy soil, now forms a rich agricultural district, scarcely equalled in the kingdom."

The spelling with $e$ instead of $a$ seems to indicate that M.E. $a$ was advanced before $r$ at an early period (see Phonology, $\S 7$ ). The disappearance of $r$ before $s$ is a frequent phenomenon (see Phonology, §7). 
Soon after the Norman Conquest, a noble family of the name of Basset ${ }^{1}$ is found in this hundred; they evidently take their name from the property owned by them in the division. See Colston-Basset.

BASSINGFIELD [bæzinfīld]?

$$
\begin{aligned}
& \text { I086 }\left\{\begin{array}{l}
\text { Basinfelt } \\
\text { Basingfeld }
\end{array}\right\} \text { D.B. } \\
& \text { I284 Bassingfeld, F.A. } \\
& \text { I } 571 \text { Basingefeild, Index. }
\end{aligned}
$$

"The field of Basing," or, more probably, "of the Basings."

BATHLEY [bætli]?

$$
\begin{array}{ll}
\text { I086 } & \text { Badeleie, D.B. } \\
\text { I316 } & \text { Batheleye, F.A. } \\
\text { I452 Bathley, Index. }
\end{array}
$$

"The lea of the bath," "the meadow, containing a bathingplace." Cæsar (De bello Gallico, IV, I) informs us that the Germans were very fond of bathing in the open ${ }^{2}$, so that it is very natural that they should have left traces of that habit in pl. ns. There are numerous such names to be encountered on the continent, as Wiesbaden, "baths in the meadow(s)," Baden of which there are several, from O.H.G. az badun, "at the baths." The English Bath appears as at Bađum (dat. pl.) in O.E. records.

The first element may, however, represent the O.E. man's name Bada which was later on changed into Bath by popular etymology.

The pronunciation recorded above is not well authenticated; in any case it would be difficult to account for the $t$.

Beauvale (Priory) [bouveil].

$$
\text { Type I (Latin). }
$$

I29I (Conventus de) Bella Valle, Tax. Eccles.

c. 1500 Bellavalle, Inq. P.M. c. 1500.

1535 (Prioratus de) Bella Valle, Valor Eccles.

1 Several members of this family are mentioned in documents relating to Notts. and Leicestershire printed in "Calendar of Documents Preserved in France" (Index).

2 By the time of Tacitus they seem to have become more averse to this violent practice (Germania, ch. XXII). 


\section{Type II (French).}

c. I 500 Beauvale, Inq. P.M. c. 1500 .

Type III (Phonetic or English).

c. I 500 Bovall [for "Bovale” ?], Inq. P.M. c. I 500 .

I637 Bonall [ $n$ for $u=v$ ], Map in Camden.

The etymology of this name is clear. It is, however, doubtful whether priority belongs to the Latin or French type. This is an instance of the comparatively rare purely Norman-French pl. ns. in England. Whereas the names of places of Germanic origin are generally of a most commonplace and strictly "practical" character, these Norman names frequently refer to the beauty of the surroundings: the imperious conquerors were able to pick and choose the site of their dwellings. Similar cases are Beaulieu, Beauchief, Beaumont, Beauchamp. (See Bradley, Essays and Studies, I, p. 39.)

It may be mentioned here that the valley in which the ruins of the priory are situated fully deserves the appellation.

BECK.

From Scandinavian bekk(r), "brook."

Beckingham.

I086 Beching(e)ham, D.B.

I I 89. Bekingeha, P.R.

12 16-72 Beghenham, Index.

1316 Bekyngham, F.A.

I637 Beckingham-Supermost, Map in Camden.

"The home of the Beccings, the descendants or family of Becca." Camden's addition explains itself.

BEESTHORPE.

$$
\begin{aligned}
& \text { I086 Bestorp, D.B. } \\
& \text { I } 204 \text { Bestorp, Index. }
\end{aligned}
$$

The first element of this name may be a pers. n. ${ }^{*} B \bar{e}$ or ${ }^{*} B \bar{e} s$ of which I cannot find reliable traces ${ }^{1}$ : there is a Beesby in

1 The M.E. name Bee (from Beatrice) recorded in Bardsley's Dictionary of Engl. and Welsh Surnames is a late formation and cannot be used to explain the form of D.B. It is equally impossible, for obvious reasons, to connect this and the following pl. n. with the female St Bee. 
Lincolnshire. It is also possible that Bees stands for an old river-name. (See Beeston.)

Beeston [bīsn] (Beesun, Hope).

1086 Bestune, D.B.

c. I 200 Bestona, Woll. MSS.

I 284 Beston, F.A.

There may have been an old pers. n. ${ }^{*} B \bar{e}$ or ${ }^{*} B \bar{e} s$ from which the pl. $n$. is derived. Numerous Beestons are found in various parts of England, in Cheshire, Bedford, the West Riding, and Norfolk. Some of these are derived from Bedestīn, "the farm of Bede." Dr Moorman (Place-Names of the W. Riding, p. 24) assumes an earlier Beowestīn as the origin of the Beeston in his district. For this there is, however, no authority.

Considering that many places take their names from the rivers on which they stand (Bradley, Essays and Studies by Members of the English Association, I, p. 32), one might advance the theory that Beeston is derived from an old river-name * Beos-e $a$. This assumption is based on the occurrence of such a name on the continent: a river Biese (O.H.G. Bese, Förstemann, II) joins the Aland in the northern part of the province of Saxony. As many river-names were brought over from the continent by the Anglo-Saxons, this particular one might have been among them (Jellinghaus, Angl. xx, 257 sqq.).

\section{BeLvoIr (Vale of) [bìvə, belvoì].}

I 535-43 The vale of Bever, baren of Wood, is large and very plentiful of good Corne and Grasse, and lyith in 3. Shires, Leycester, Lincoln, and much in Notting$\left.\begin{array}{c}\text { hamshire } \\ \text { Beavoire (Castelle) }\end{array}\right\}$ Leland, I, 108.

1613 Bever's batning slade, Drayton, Polyolbion, Xxvi, 2.

Although Belvoir Castel is situated in Leicestershire, the name is included because the Vale of $B$. lies partly in Notts. The etymology is obvious. Unlike the majority of modern Bellevues and similar names, the Castle well deserves its appellation. Cp. Beauvale. 
BESTHORPE.

$$
\begin{aligned}
& \text { I086 Bestorp, D.B. } \\
& \text { I302 Besthorp, F.A. }
\end{aligned}
$$

This name seems to be identical in origin with Beesthorpe (q.v.), with the vowel shortened before the combination $s p$.

$$
\text { Bestwood (Park). }
$$

$$
\text { Type } I \text {. }
$$

c. I200 Beescwde, Woll. MSS.

I205 $\left.\begin{array}{l}\text { Beswude } \\ \text { I } 247\end{array}\right\}$ Cal. Rot. Chart.

I 535-43 Beskewood, Leland.

I637 Beskwood, Map in Camden.

\section{Type II.}

$\left.\begin{array}{l}\text { I437 } \\ \text { 168 I }\end{array}\right\}$ Bestwood Park, Index.

"The enclosed wood where deer are preserved." In meaning, this word corresponds to the O.E. deor-frid. Although the earliest spellings exhibit $k^{1}$ instead of $t, \mathrm{I}$ take the latter to be the original letter which was changed to $k$ through assimilation (see Phonology, § I3). Thoroton informs us (vol. II, p. I79) that the park was "well stored with deer before the troubles" (i.e. the Civil War?). White's Directory (I885) contains a note to the effect that in 125 I Bestwood was "a Hay or Park of our Lord the King wherein no man commons."

Bevercoates.

I 302 Bevercotes, F.A.

I637 Bircotes, Map in Camden.

O.E. beofor cotu, "the beaver cotes or dwellings." In the transition from O.E. to M.E. the distinctions of grammatical gender were completely lost, and the originally neuter cot assumed the plural ending -es of the masculine nouns (Sweet, N. Engl. Grammar, § 989).

1 The $c$ in the spelling of the Woll. MSS. may be a mistake for $t$; the two letters are frequently interchanged by the scribes on account of their almost identical shape. 
This name proves that beavers once were not infrequent inhabitants of this island (cf. Taylor, Words and Places, ch. $\mathrm{xV}$ ). In the neighbourhood of Bevercoates there is an abundance of brooks and springs; originally the country must have been a wild swamp, just the place for beavers to erect their constructions.

Camden's spelling no doubt represents the contemporary pronunciation.

Bilborough.

$$
\begin{array}{ll}
\text { I086 } & \text { Bileburg(h), D.B. } \\
\text { I I } 80 & \text { Billeburg, Woll. MSS. } \\
\text { I } 284 & \text { Bilburgh, F.A. }
\end{array}
$$

"The burh or fortified place of Billa."

BILBy.

$$
\begin{aligned}
& 1086 \text { Billebi, D.B. } \\
& \text { 1316 Bylby, F.A. }
\end{aligned}
$$

"The byr or farmstead of Billa." The second element is of Scandinavian origin; but the pers. n. Billa may be either O.E. or Scand.

BilHaGH (a wood of Sherwood Forest).

$$
\text { I637 Bellow, Map in Camden. }
$$

The second element is O.E. hazu, "a fence, a piece of ground enclosed with a fence." As to the meaning of the first element I have no suggestion to offer. Camden's spelling probably represents the contemporary pronunciation.

BILSTHORPE.

$$
\begin{aligned}
& \text { I086 Bildestorp, D.B. } \\
& 1233 \text { Bilsthorpe, Index. } \\
& \text { I29I Bildisthorp, Tax. Eccl. } \\
& \left.\begin{array}{ll}
1302 & \text { Bildesthorp } \\
1428 & \text { Bilsthorp }
\end{array}\right\} \text { F.A. }
\end{aligned}
$$

This name probably means "Bilheardes borp." The pers. $\mathrm{n}$. Bilheard is recorded once (Onomasticon). The phonetic development-a continual process of elimination-was as follows: 
Bilheardesporp $>$ Bilrdesporp $>$ Bildesporp $>$ Bilsporp. It is, however, possible that the first element was the Scand. pers. n. Bildi (more usually Billi), recorded by Rygh, Gamle Personnavne, p. 36. The Scand. character of the second element speaks in favour of such a derivation.

\section{BinghaM.}

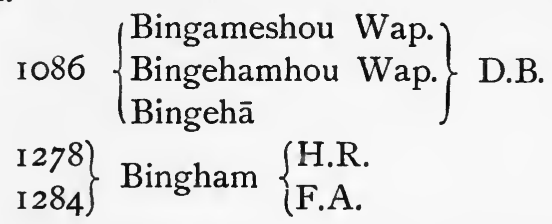

I 578 Bingham in le Vale, Index.

"The home of the family of Benning," O.E. Benninga häm. A contracted *Bengham would become Bingham (see Phonology, $\S 6)$. In a charter (Cart. Sax. 125) we find the name Benninga wurth; there is a Binningham in Yorkshire which is spelt Beningham in 1303 (Index), and a Binnington in the same county which appears as Benington in I 555 (Index). The same patronymic is encountered in continental pl. ns., cf. Binningen (Förstemann, II). Hou in D.B. is derived from O.E. hōw, "a hill"; hundreds and wapentakes were frequently called' after hills; see Bassetlaw.

\section{BIRKLAND (ancient wood of Sherwood Forest).}

I 278 foresta dni Reg' int[er] Birkelund \& Heselund, H.R.

The meaning is clearly "Birch wood." Both elements of this name are of Scandinavian origin. The former is cognate with O. Icelandic birki-, "a birch" (in compounds only, Vgf.); the word is not mentioned in Björkman's book on Scandinavian Loan Words. The suffix is the Scand. lundr, "a wood," still found, in various forms, in the English dialects, also as an independent pl. n. ; see Lound. It was changed to -land through popular etymology. This new termination may stand for either the common word land, " expanse of country," or M.E. land, laund, "wild, shrubby, or grassy plain," derived from O. French lande. 
Bleasby.

I278 Blesby, H.R.
I302 Bleseby, F.A.

Various explanations may be offered, although none seems conclusive:

(I) "The $b \bar{y} r$ of the blast, the windy habitation"; from O.E. blēs, "a blowing, blast." The same element seems to occur in the Lancs. pl. n. Bleasdale, which, however, is explained differently by Prof. Wyld (cp. Lowdham).

(2) There may have existed a pers. n. *Bl̄esa corresponding to the O.H.G. Blâso in Blasindorf (Förstemann, I).

(3) The first element may contain the name of a river or brook (cp. Beeston). We find two rivers called Blies in Germany (cp. Förstemann, II, s.v. Blesa flumen).

BLIDWORTH.

1086 Blideworde, D.B.

I 57 Blieswurda, P.R.

I278 Blytheworth, H.R.

I 598 Blodworth, Index.

1637 Bledworth, Map in Camden.

"The weorb or farm of Blïpa"? Before $w, \delta$ seems to have become stopped and changed to $d$. The P.R. form shows loss of intervocalic $\delta$, pointing back to an O.E. Blides-weorb. It is remarkable that the other forms are without the genitival $s$. The pers. n., which is not recorded in the assumed form, seems to be an abbreviated variety of one of the many names beginning with Blid-, as Bliðhelm, -here, -mund, -weald etc. (Onomasticon). The two last quotations appear to be no more than fanciful or erroneous spellings.

BLYTH [blaið].

1086 Blide, D.B.

I 53 (?) Blie, Index.

$1278\left\{\begin{array}{l}\text { Blid' } \\ \text { (Prior de) Blida }\end{array}\right\}$ H.R.

1316 Blid, F.A.

1327-77 $\left\{\begin{array}{l}\text { Blida } \\ \text { Blyth }\end{array}\right\}$ Non. Inq.

M. 
There are a considerable number of rivers called Blyth in various parts of England. I take the above name to be derived from the river on which the town stands. The place was originally

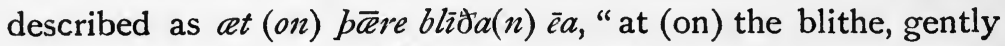
flowing, calm brook." The $e$ in the second spelling and the $-a$ in the latinised Blida above seem to point to the second element having at one time been $\bar{e} a$. The word blithe, "laetus, suavis, placidus," is a very appropriate epithet for many of the English streams. I was unable to find a brook of that name near the town of Blyth; the following extract from Leland's Itinerary ( $\mathrm{I}, 98)$, however, proves that one of the water-courses in the neighbourhood once bore that name: "There renne to Brookes as I cam into the Toun of Blith, the first that I cam over was the Greatter, and cummith thither from the Weste: the other rennith hard by the utter Houses of the Toun; and this, as they told me, was namid Blith."

N.B. The O.E. nom. of the name of the river, which preceded that of the town, was $b l \bar{\imath} \partial u \bar{e} a$, or sēo blïde $\bar{e} a$.

BOLE.

\section{Type I.}

I086 Bolun, D.B.

\section{Type II.}

I316 Bole, F.A.

I 327-77 Bole super Trent, Non. Inq.

I 555 Bolle, Index.

It is impossible to say which is the correct etymology of this name. Type I seems to represent the O.E. dat. pl. of bold, "building, dwelling, house" (see Bülbring, §522); Type II would, in that case, stand for the dat. sing. The $d$ after $l$ was assimilated at an early period. The course of development would be as follows: Bolde $>$ Bolle $>$ Boule $>$ Bole; the modern spelling correctly indicates the pronunciation but not the etymology.

BOLHAM or BOLLAM.

$$
\left.\begin{array}{l}
\text { I } 278 \\
\text { I } 335
\end{array}\right\} \text { Bolum }\left\{\begin{array}{l}
\text { H.R. } \\
\text { Index. }
\end{array}\right.
$$

O.E. at bóldum, "at the dwellings, houses," see the preceding 
name. The spelling in -ham is due to a misconception as to the nature of the final syllable.

It is not improbable that the "dwellings" referred to were ancient rock-houses of which traces are still to be found. White's Directory (I853) may be quoted here: "The village formerly had numerous rock-houses formed by excavations in the shelving rock of red sandstone, but few of these troglodyte dwellings are now inhabited."

BONBUSK.

I 57 I Bonbusk, Index.

"Bonda's bush, or coppice" ? The name Bonda is very frequent in East Scandinavian sources; see Björkman. The M.E. buske is also of Scandinavian origin.

BONINGTON.

1086 Bonniton, D.B.

I29I Bonigton, Tax. Eccl.

I 327-77 Bonyton, Non. Inq.

I 346 Bonyngton, F.A.

O.E. Boninga tūn, "the homestead of the descendants of Bona." A family of the name of Baningas is mentioned in the O.E. poem $W i d s i b$, line I9. The $a$ before a nasal was frequently changed to $o$; Bülbring, $§ 123$.

The same patronymic is encountered in continental pl. ns. Förstemann, I, records the following: Boningaham, and Boningue, near Calais.

BothamSALl or BotTomSALl [locally: boðmsəl; otherwise: botmsəl] (Bottomsall, Hope).

\section{Type $I$.}

I 535 Bodv'sell, Val. Eccl.

Type II.

(I) $\quad$ I086 Bodmescel(d), D.B.

I 180 Bodemeskil, Index.

(2) c. I200 Bodmeshil, Index.

I278 Bodmeshill, H.R. 
(3) 1225 Botmeshil, Index.

(4) 1302 Bothemeshull

1 316 Bothemeshul F.A.

"The well or spring of Bodwine (or *Bodmāer?)." From Type II I, the earliest spellings on record, we clearly gather that the second element was the Scand. kelda, "a spring or well." A flowing well is still to be seen in a field in the centre of the village; its water supplies a trough standing in the main road. It is very probably the original spring after which the locality is called.

There exists some doubt as to the exact significance of the first element. The name Bodwine is frequently found in O.E. documents, but a trace of the $w$ is nowhere preserved except in the solitary instance under Type I. All the other spellings contain $m$, which, however, may be the result of the coalescence of $w$ and $n$, the $m$ taking the lip-action from the former, and the nasalisation from the latter sound (cp. Rampton < Rafn-). It is, therefore, not absolutely necessary to assume the existence of an O.E. pers. n. Bodmēer, of which there are no other traces, but which would correspond to the O.H.G. Botmar (Förstemann, I).

It is not difficult to explain the variety of spellings recorded of this name. The $t$ of Type II 3 and the modern pronunciation arose out of confusion with the noun "bottom." Intervocalic $d$ seems to become open in the dialect (Type II 4 and local pronunciation). The $k$ after the $s$ has been assimilated, but the latter retained its voiceless quality. Various spellings show an attempt on the part of the writers to connect the second element with " hill."

BoughtoN [būtn].

\section{Type $I$.}

I086 Buchetun, D.B.

1225 Buketon, Index.

I316 Bucketon, F.A.

I 3 I 8 Bucton, Index. 


\section{Type II.}

$\left.\begin{array}{c}\text { 1327-77 } \\ 1346 \\ 1377 \\ 1535\end{array}\right\}$ Bughton $\left\{\begin{array}{l}\text { Non. Inq. } \\ \text { F.A. } \\ \text { Index. } \\ \text { Val. Eccl. }\end{array}\right.$

I 57 I Boughton, Index.

\section{Type III.}

\section{I346 Button, F.A.}

"The $t \bar{u} n$ or farmstead of Bucca." The phonetic development of this word presents a number of interesting features. The $k$ preserved in Type I was opened before $t$ (Phonology, $\S 20$ ); the result was the first form of Type II, pronounced [buxton]. Before the $g h[\mathrm{x}]$, an $u$-glide arose which, combined with the original $u$, formed a long vowel $[\overline{\mathrm{u}}]$ spelt $o u$ in the second form of Type II, and the modern name. Curiously enough, this $\bar{u}$ does not seem to have been diphthongised, probably on account of the preceding labial (see Phonology, § 4).

Type III shows assimilation of $k$ to $t$ (Phonology, §. I 3 ).

BRADEBusK (in Gonalston Parish).

c. 1500 Brodebuske, Inq. P.M. c. I 500.

"The broad bush." The second element is the Scand. busk (cf. Bonbusk). Brode-is a variant of broad; the $a$ in open syllable, found in the modern spelling, points to the influence of Scand. breitr.

Of this place nothing is left but the ruins of a hospital, which derived its name "from a remarkably broad thorn tree which grew near it" (White, Directory, I853, p. 489).

BRADMORE.

$$
\text { Type } I \text {. }
$$

I086 Brademere, D.B.

I216-1307 Brademar, Testa de N.

1294 Brademare, Woll. MSS.

I 302 Brademere, F.A.

\section{Type II.}

c. 1500 Bradmore, Inq. P.M. c. 1500 .

I534 Brademore, Index. 
"The broad lake, or pool." The original mere of Type I was later on replaced by the more familiar more, moor. The first element stands for O.E. brād, "broad," with the vowel shortened before the combination $d m$ (Phonology, $\S \mathrm{I}$ ).

BRAMCOTE [bræmkət].

$$
\begin{gathered}
\text { Type } I . \\
\text { I086 }\left\{\begin{array}{l}
\text { Broncote } \\
\text { Brunecote }
\end{array}\right\} \text { D.B. } \\
\text { c. I } 200 \text { Brancote, Woll. MSS. }
\end{gathered}
$$

Type II.

c. I200 Bramcote, Woll. MSS. $\left.\begin{array}{l}\text { I } 284 \\ \text { I } 6 \text { 6 }\end{array}\right\}$ Bramcote, F.A.

$$
\left.\begin{array}{c}
\text { Type III. } \\
{ }_{1426}
\end{array}\right\} \text { Brauncote, F.A. }
$$

"The cot or dwelling in the place cleared of brushwood by means of fire." The first element I take to be M.E. brand which is recorded in the N.E.D. as meaning the "act, means or result of burning." Instances of its occurrence in pl. ns. are given by Prof. Wyld (Lancs. Pl. Ns. p. 297). On the continent this element occurs frequently in place nomenclature.

Type I retains the original $n$, the $d$ having been lost between the two consonants. The $o$ of the first D.B. spelling may stand for $a$ before nasals (Stolze, $\S 2$ ), or $u$ as in the alternative spelling. This $u$ is a mistake of the D.B. scribe, who was probably thinking of the rather frequent pers. n. Brinn. The change of $n$ to $m$ in Type II is due to the assimilatory influence of the initial $b$ (see Phonology, § I3). Type III represents the Anglo-French pronunciation of $a$ before nasals (Phonology, $\S$ I I).

N.B. It would also be admissible to derive the name from Brand, a pers. $n$. of Scandinavian origin (see Björkman).

BRECKS ("The Brecks," a tract of light forest land to the west of Boughton).

This word is of Scand. origin; it comes from brekka, "a slope" (Vgf.). Neither the N.E.D. nor the Dial. Dict. contains it. 
BRENTSHILL (a lofty eminence covered with traces of ancient earthworks, near Barton).

"The steep hill"? With this name may be compared Brent $K$ noll near Athelney in Somersetshire which also shows traces of an old camp. The first element seems to be the dialect word (Yks., Leics.) brent, "steep." The $s$ may be regarded as a late addition that owes its existence to the erroneous assumption that the first part of a compound pl. n. must appear in the genitive case. (Cp. Merrils Bridge.)

BRIDGEFORD Or BRIDGFORD (East).

I086 Brugeford, D.B.

I 302 Brigeford, F.A.

I 345 Estbryggeford, Index.

"The ford by the (ruined) bridge"? The $u$ of D.B. stands for O.E. $y$ (Stolze, $§$ I 5). In Roman times, the place seems to have been called "ad pontem," but this is by no means established (Victoria County History, II, pp. 6, 7, I7).

It is quite true that no traces of a Roman bridge have been discovered. The original Roman bridge may have been a wooden structure which was allowed to decay in post-Roman times.

BRIDGEFORD or BRIDGFORD (West).

I086 Brigeforde, D.B.

I 203 Brigiford, Index.

I 302 Briggeford ad Pontem, F.A.

There has been a bridge at this place since the days of Edward the Elder (924), so that the ending "ford" seems somewhat out of place. It is, however, possible that "ford" means "road across a river," whatever the actual means of passing from one bank to the other may be. Or is "ford" a name that can be applied to any place on a river or brook?

BRINSLEY.

$$
\text { Type } I \text {. }
$$

I086 Brunesleia, D.B.

I216-I307 Brunesleg, Testa de N.

I29I Brunnesley, Tax. Eccl.

I312 Brunnesleye, Woll. MSS. 


\section{Type II.}

I I6-1307 Brinseley, Testa de N.

I 316 Brinnesleye, F.A.

"The lēah or open field of Brün, or Brȳne." The name Briun is very frequent in O.E.; the variant Bryne (Type II) seems to have taken its place and survived ${ }^{1}$. At the time of the D.B. survey, a man called Brīn held four bovates in this place: it is highly probable that he was the owner or settler who gave his name to the locality. In that case, Type II is due to analogy with the co-existing variant Bryne. If this is correct, Brinsley would be one of the very few pl. ns. called after persons about whom anything is known.

BRoAdHolme.

$\left.\begin{array}{l}\text { I086 Brodeholm, D.B. } \\ \text { I } 160 \\ \text { I } 291 \\ \text { I } 428\end{array}\right\}$ Brodholm $\left\{\begin{array}{l}\text { Index. } \\ \text { Tax. Eccl. } \\ \text { F.A. } \\ \text { I637 Bradham, Map in Camden. } \\ \text { I704 Brodham, Map of I704. }\end{array}\right.$

"The broad holme, or island." The word *holm is probably of Scand. origin. The $o$ for O.E. $\bar{a}$ in the D.B. entry is remarkable, as the change of $\bar{a}$ to M.E. $\bar{Q}$ is not, as a rule, found as early as the date of the great survey (Stolze, $§ 3$ ).

The spellings of 1637 and 1704 represent attempts at etymology. Camden's $a$ in the first syllable may be due to early shortening of $\bar{a}$ before $d h$ (cp. Bradmore.)

BROUGH [braf].

"The burh, or fortified place." In Thoroton's History (I 7 th cent.) the place is called Bruff; by that time it was "only a name." It is derived from O.E. buruh, a designation applied to fortified places, especially to all walled towns and camps. Brough is the site of the Roman station called Crocolana (MacClure, p. I09).

1 It is, however, not impossible that the $u$ of Type I may represent a Norman rendering of the sound of the rounded O.E. $\bar{y}$. 
BROUGHTON (Upper) [brōtn].

\section{Type $I$.}

I086 Brotone, D.B.

I29I Brocton, Tax. Eccl.

I3I6 Brokton, F.A.

Type II.

I 346 Broghton, F.A.

I 57 I Broughton, Index.

Type III.

I 302 Brotton, F.A.

"The tün or farmstead by the brook." The development of the O.E. Broctuin is similar to that of Boughton (q.v.). Before the $k t, \bar{o}$ was shortened (Type I); then $k t$ became $h t$ (Type II I), then an $u$-glide developed (Type II 2). M.E. ou seems to be represented by $\bar{\rho}$ in the modern dialect (Phonology, §9). Type III shows assimilation, $k t>t t$.

Upper Broughton occupies the eastern slope of a steep hill overlooking the Leicestershire village of Nether Broughton.

BROXTOW (formerly the name of a hundred; it now appears in Broxtow Hall, a farmhouse in the parish of Bilborough).

I086 $\left\{\begin{array}{l}\text { Brocolvestou } \\ \text { Brochelestou } \\ \text { Brolvestou } \\ \text { Bruchelestou }\end{array}\right\}$ D.B.

$\left.\begin{array}{ll}\text { c. I I75 Brocolvestou } \\ \text { c. I I90 Brogcholvestowe }\end{array}\right\}$ Woll. MSS.

$\left.\begin{array}{ll}\text { I } 284 & \text { Brocolstowe } \\ \text { I } 428 & \text { Brokestowe }\end{array}\right\}$ F.A.

I 457 Brocholwestouwa alias Brokestou, Index.

c. I $500\left\{\begin{array}{l}\text { Brokstowe } \\ \operatorname{Brox}(\mathrm{t}) \text { all }\end{array}\right\}$ Inq. P.M. c. I 500 .

O.E. Brōczulfes stōw, " the place of Bröczulf." The operation of various phonetic laws has produced a vast number of more and more abbreviated forms.

Although the pers. $n$. involved is not recorded in the Onomasticon, it must have existed in O.E., as would appear 
from this pl. $\mathrm{n}$. and the one found in the Crawford Charters (p. 70). The name is found as Proculf in O.H.G. (Förstemann, I).

The second element is of somewhat doubtful meaning. It is usually employed in O.E. as signifying "place, locality"; very often, however, its sense is that of "sacred site, burial-place" (see Middendorf, s.v.). In the present case it may have the latter meaning. If so, Broxtow would have been the burialplace or mound of a certain Broczoulf, where the men of the hundred assembled.

Isaac Taylor explains the name as meaning "place at the Badger's hole" which is, of course, untenable.

BUDBY.

$$
\begin{aligned}
& \text { I086 Butebi, D.B. } \\
& \text { I278 } \\
& \text { I } 36\} \text { Buteby }\left\{\begin{array}{l}
\text { H.R. } \\
\text { F.A. }
\end{array}\right.
\end{aligned}
$$

"The bȳr or farmstead of Bütr, or Butti." The second element being of undoubtedly Scand. origin, the same may be expected of the first. The names Bütr and Butti are not found in English sources, but are recorded by Rygh (Gamle Personnavne). The change from $t$ to $d$ is due to the voicing influence of the surrounding sounds.

N.B. The O.E. name Budda can hardly be contained in the pl. n. seeing that the early spellings all exhibit a $t$.

Bulcote [būkə].

$$
\begin{aligned}
& \text { I086 Bulecote, D.B. } \\
& \text { I278 } \begin{array}{l}
\text { Bulkete, H.R. } \\
\text { I302 } \left.\begin{array}{l}
\text { Bolcote } \\
\text { Bulcote }
\end{array}\right\} \text { F.A. }
\end{array}
\end{aligned}
$$

I637 Boucot, Map in Camden.

"The cote of the bull, the cattle shed." The O.E. equivalent of modern "bull" occurs in compounds-only; this is one of those cases. A parallel name is found in Lambcote (q.v.).

BULWELL [locally: bulal; otherwise: bulwal].

I086 Bulewelle, D.B.

I3I6 Bolewell, F.A. 
The meaning of the second element is clear. As to the first, various explanations may be offered:

(I) It may stand for the O.E. pers. n. Bulla.

(2) It may represent the O.E. *bule, "a bull" (see prec. name).

(3) It may describe the sound produced by the flowing water of the spring. Although I am unable to suggest what the exact form of the O.E. name was, I feel sure that this latter is the correct explanation. The well or spring from which the locality derives its name is still in existence and known to the people as "the Bulwell" without any addition; on the maps it is marked "Bulwell Spring." There is a copious flow of brilliantly clear water rushing out of the red sandstone with a bubbling ${ }^{1}$ noise. In a few places the water rises from the bottom of a small pool as if it were boiling. In the N.E.D. the noun bulling is recorded as occurring once, describing "the action of water issuing from a spring, bubbling." It is there compared with French bouillir, Latin bullive; but it is evident that both are independent onomatopoefic formations ${ }^{2}$. The same word is encountered in German with the addition of a frequentative $r$ : bullern, "Blasen werfend geräuschvoll aufwallen; ein dumpfes Geräusch machen."

BunNy.

$$
\left.\begin{array}{rl}
\text { I086 } & \text { Bonei, D.B. } \\
\text { I227-77 } \\
\text { I 284 }
\end{array}\right\} \text { Boneye }\left\{\begin{array}{l}
\text { Non. Inq. } \\
\text { F.A. }
\end{array}\right.
$$

1 This word is derived from * bullan by reduplication, often found in onomatopoetic formations : cp. the German surren and the Latin susurrare.

2 This particular combination of sounds is such a perfect imitation of the noise of "bubbling" water that it is often formed ad hoc and independently. The following quotations will show how onomatopoetic words come into existence, affording at the same time a welcome illustration and parallel of the origin of the pl. n. under discussion. They are taken from one of the most typical works of German Romanticism, Bettina von Arnim's "Goethes Briefwechsel mit einem Kinde" (Reclam's edition). " "...und dann die runde grüne Quelle, an der wir standen, die so ewig über sich sprudelt, bul, bul, und Du sagtest, sie rufe der Nachtigall..." (p. 287). "Dort im Park zu Weimar gingen wir Hand in Hand unter den dichtbelaubten Bäumen, das Mondlicht fiel ein...dann führtest Du mich an die Quelle, sie kam mitten aus dem Rasen hervor, wie eine grüne krystallne Kugel, da standen wir eine Weile und hörten ihrem Getön zu. 'Sie ruft der Nachtigall,' sagtest Du, 'denn die heisst auf persisch Bulbul..." " (p. 565). 
Thoroton in his History ( $\mathrm{I}, \mathrm{p} .85$ ) gives the correct etymology: "Probably from Reeds." O.E. at bune é $3 e$, "at the water full of reeds"; the O.E. and M.E. bune of uncertain derivation is translated by "canna, harundo, calamus" in early glossaries (see N.E.D., bun, sb.). The modern English meaning of bun is "a hollow stem, especially of an umbelliferous plant, a kex"; compare Fitzherbert, Husbandry ( 1523 ) : "The...lowe places, and all the holowe bunnes and pypes that grow therin" (1.c.).

Burton JOYCE.

\section{Type $I$.}

I086 Bertune, D.B.

\section{Type II.}

c. I I70 Birtona, Woll. MSS.

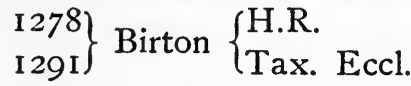

$\left.\begin{array}{ll}\text { I } 302 & \text { Byrton } \\ 1428 & \text { Birton }\end{array}\right\}$ F.A.

Type III.

1428 Burton Jorce, F.A.

I 535 Burton Jorth, Joys, Val. Eccl.

Type $I$ is one of the numerous blunders of the D.B. scribes. It might stand for O.E. beorg tün, "the farm on the hill"; but this sense is quite different from that of the more numerous and reliable spellings that follow.

Type II = O.E. byrih tün, "the farm by the fortified place"; Type III = O.E. buruh tün meaning the same thing; buruh and byrih are variants of the same word.

The addition of Joyce is accounted for by the place having once been in the possession of that family: "Robertus de Jorz tenet in B." (F.A. I 302).

Burton (West).

$$
\left.\begin{array}{l}
\text { I086 Burtone, D.B. } \\
\text { I29I } \\
\text { I3 I6 } \\
\text { I428 }
\end{array}\right\} \text { Burton }\left\{\begin{array}{l}
\text { Tax. Eccl. } \\
\text { F.A. } \\
\text { F.A. }
\end{array}\right.
$$

See preceding name, Type III. 
BYCARDYKE.

I 89 Bikeresdic, Nottm. Ch.

I $278\left\{\begin{array}{l}\text { Bikerisdick } \\ \text { Bikerisdik }\end{array}\right\}$ H.R.

The second element is O.E. dīc, "ditch," as it developed on Northumbrian territory, with $k$ instead of $t \int$ (Bülbring, $\left.\$ 496\right)$. It is difficult to say what the first element is. It may stand for O.N. bekkr, "brook," with the nominatival $r$ preserved, and the English $s$ added as a sign of the genitive. It is also possible that the original compound was bekkjar dic, bekkjar being the regular O.N. genitive form, and that later on a superfluous $s$ was added when the original meaning of er had become obliterated. If so, the meaning would be "the dyke of the brook."

The West Riding pl. n. Bickerton is explained by Prof. Moorman as meaning "the enclosure by the water"; Bickerstaffe in Lancashire contains the same first element. Prof. Wyld translates it by "the shore of the brook" (Lancs. Pl. Ns., s.v.).

The transition from $e$ to $i$ in the first syllable is probably due to the influence of the following $k$ : the change bekkr, bekkjar > M.E. bicker is similar to that from O.E. strec, "straight," to Northern M.E. stric (Morsbach, M.E. Gramm. § IO9).

The modern spelling does not contain $s$, and probably goes back to the original type bekkjar (bekkr) dic. It has a somewhat fantastic appearance, having been influenced by analogy of the preposition $b y$, and car, a dialect word meaning "swamp, bog" (see Carburton).

CALverton ["vulgarly": kōvətn; otherwise: kāvətn, kælvətn].

$$
\begin{aligned}
& 1086 \text { Calvretone, D.B. } \\
& \text { I } 284 \text { Calverton, F.A. }
\end{aligned}
$$

O.E. (Mercian) calfra tūn, "the enclosure of the calves." The sound development presents many interesting details. The third pronunciation recorded above is entirely based on the modern spelling.

Carburton or Carberton. I086 Carbertone, D.B.

I 278 Carberton, H.R. 
"The barley-enclosure, or grange, on the marshy land, or car." See Barton with which it is identical. The prefixed car meaning "a pool, low-lying land apt to be flooded, boggy grass land" (Dial. Dict.) is derived from Scand. kiarr, "marshy ground."

CAR Colston.

Io86 Colestone, D.B.

1216-1307 $\left\{\begin{array}{l}\text { Kercolmston } \\ \text { Kyrkholmston }\end{array}\right\}$ Testa de N.

$\left.\begin{array}{ll}1284 & \text { Kercolston } \\ 1428 & \text { Kyrkalston }\end{array}\right\}$ F.A.

"The farmstead of Col in the bog." The man's name Col may be of O.E. or Scand. origin; Dr Björkman is inclined to take the latter view. The Testa de N. spellings are fantastical attempts at etymology. For car see preceding name.

Carlton (near Nottingham).

I086 Carentune, D.B.

I 302 Carleton, F.A.

CARLTON-IN-LindRick.

I086 $\left\{\begin{array}{l}\text { Caretone } \\ \text { Carletone } \\ \text { Careltune }\end{array}\right\}$ D.B.

I 135-54 Carletuna, Index.

I29I Karleton in Lyndryk, Tax. Eccl.

CARLTON (South or Little).

I I99-I 2 I6 Karleton, Index.

Carlton-upon-Trent.

I086 $\left\{\begin{array}{l}\text { Carletone } \\ \text { Carentune }\end{array}\right\}$ D.B.

It is difficult, if not impossible, to say with any degree of certainty whether the first element of these names is the Scand. noun carl, corresponding to the O.E. ceorl, or a pers. name, either Carl, or Carla. Dr Björkman seems to be in favour of the latter explanation (p. 78), whereas Isaac Taylor (Engl. Village Names, §3), Prof. Skeat (Pl. Ns. of Beds., s.v. Charlton), 
Prof. Wyld (Pl. Ns. of Lancs. p. 93) and Prof. Moorman (P1. Ns. of W. Riding, pp. xvi, 42) adopt the former. According to the last named authority, the O.E. prototypes were carla tūn, carla being the gen. pl. of Scand. karl, or carlana tün, with substitution of the weak gen. pl. carlana for the strong form carla (Sievers, $§ 257$, anm. 4). The meaning of the place-names would be "the enclosure of the freemen." The meaning of ceorl, karl was not always that of the present-day churl or carl, which are descended from them. It was used in legal language to denote the freeman standing between the noble and the slave.

The curious early spellings noted in the above list with its omissions and transformations offer no difficulty to anyone acquainted with the vagaries of Anglo-Norman scribes.

Lindrick = "lime-wood," from O.E. lind, " a lime-tree," and *ric, which seems to be identical with Low German ricke, “tractus, Hag, längliches Gebüsch." See Jellinghaus, who quotes the Westphalian pl. n. Bockryck, "beech copse."

Caunton.

$$
\begin{aligned}
& \text { Type I. } \\
& \text { I086 }\left\{\begin{array}{l}
\text { Calnestone } \\
\text { Carletun }
\end{array}\right\} \text { D.B. } \\
& \text { I } 166-7 \text { Calnodeston, Pipe Roll XI. } \\
& \text { c. } 1200 \text { Kalnadatun } \\
& \text { c. } 1216 \text { Kalnadton }\} \text { Index. } \\
& \text { I278 Callenton, H.R. } \\
& \text { I302 Calneton }\} \text { F.A. } \\
& \text { I316 Caneton }
\end{aligned}
$$$$
\text { Type } I I \text {. }
$$

c. 1225 Calfnadtun, Index.

The various forms under Type I seem to point to a pers. $n$. *Carlnä $\bar{\delta}$ as the first element. The element nä̋ occurs in pers. ns. both in Scandinavian and West Germanic. It is, however, impossible to come to any definite conclusion unless the existence of the name ${ }^{*}$ Carlnä̃ could be authenticated. A reinvestigation of the pl. ns. Kalladaberg, Kalladaland etc., quoted by Rygh (Gamle Personnavne, pp. 155-6), whose 
explanation cannot be accepted, might, perhaps, throw light upon this question.

Type II seems a mere futile attempt at etymology on the part of the scribe.

CAYTHORP.

\author{
Type $I$. \\ $\left.\begin{array}{ll}\text { c. I I } 70 \text { Cathorp } \\ \text { c. I } 200 \text { Cattorp }\end{array}\right\}$ Woll. MSS. \\ I 3 I6 Cathorp, F.A. \\ Type II. \\ I 216-1307 Kalthorp, Testa de N.
}

There is a Caythorpe in Lincs., which appears as Carltorp in D.B. This at once settles the etymology of the pl. n. The meaning of the prefix carl, karl was discussed under Carlton (q.v.). The development was as follows : Carlborp $>$ Carrborp (Type I, which survived), or $\operatorname{Cal}(l)$ borp (Type II); $a r b>\bar{a} b$, etc. (see Phonology, § 7).

Chilwell.

\begin{tabular}{|c|c|c|}
\hline \multicolumn{3}{|c|}{ Type I. } \\
\hline & Cidwelle & \\
\hline 1086 & Chidewelle & $\mathrm{DB}$ \\
\hline 1000 & Cillewelle & D.D. \\
\hline & Ciluellis & \\
\hline I 302 & Chillewell, F & A. \\
\hline & Type II. & \\
\hline
\end{tabular}

This name also exists in Lancashire, in the modern disguise of Childwall, and is discussed by Prof. Wyld (Pl. Ns. of Lancs. p. 9I). I take the first element to be the O.E. *celd, *cild , which is not found as an independent word but appears in the Kentish pl. n. Bapchild (see Jellinghaus, Anglia, xx, 299; MacClure, p. 226). It is connected with Scand. keld, " a well, spring, pool." The second element of Chilwell being O.E. wiell,

1 O. Bulg. kladęzi, "a well," is derived from a hypothetical Gothic noun *kaldiggs which Dr Hirt takes to contain the root of modern Engl. cold (Etymologie der neuhochdeutschen Sprache, 1909, p. 45). 
well, "spring," the meaning of the whole name most probably is : "The pool containing a spring, the flowing well."

The variation in the vowel of the alternative cild and celd found in Types I and II respectively is explained by assuming that the former is the Southern, the latter the Northern O.E. form (Bülbring, \$\$ I 5 I, I 54).

Clareborough [klābrə].

I086 Claureburg, D.B.

I 89 Claverburc, P.R.

I 278 Claverburg, H.R.

I 286 Clauerburge, Index.

"The fortified place where clover grows." The vowel in the O.E. cläfre or cläfre was shortened before the combination vr; the $v$ was lost according to rule.

Clayworth or Claworth.

I086 Clauorde, D.B.

I 55 Clawurda, P.R.

1225 Clawrd, Bor. Rec.

I 278 Clawurh, H.R.

I3I6 Clauworth, F.A.

I637 Cloworth, Map in Camden.

"The farm in the clay land." It is remarkable that no ancestors of the first and most frequent form of this name have come down to us. All the early spellings, as well as the modern alternative, point to a shortening of the first element having taken place: O.E. clēezeorb > cla zweorb > claworb; before the $w$ an $u$-glide arose (F.A. of 1316) which formed a diphthong with the preceding vowel. This au had become monophthongised by the time of Camden. The principal modern form probably owes its existence to the fact that the etymology of the name had at no period become altogether obscured. The soil of this township is a rich clay.

Clifton (North and South); and Clifton near Nottingham.

$$
\text { I086 }\left\{\begin{array}{l}
\text { Cliftune } \\
\text { Clifton } \\
\text { Clistone } \\
\text { Clitone }
\end{array}\right\} \text { D.B. }
$$


The etymology of this name is obvious, especially to those who have visited the localities. The villages of North Clifton and Clifton near Nottingham are situated near long cliffs.

The curious Clistone of D.B. can puzzle only those unfamiliar with the vagaries of the Norman scribe.

Clipstone.

$$
\begin{aligned}
& \text { I086 }\left\{\begin{array}{l}
\text { Clipestone } \\
\text { Clipestune }
\end{array}\right\} \text { D.B. } \\
& \text { I } 89 \text { Clipeston, P.R. } \\
& \text { I695 Clipstow, Map in Camden. }
\end{aligned}
$$

"The tün or farmstead of Clip." The man's name Clip is recorded once as that of a moneyer (Onomasticon).

The modern spelling seems to imply that the second element was O.E. stān, "stone, rock, boundary or gravestone." There is nothing in the early spellings to support this assumption; on the contrary, the second D.B. form in particular clearly shows the second element to have been O.E. tìn. The modern name has simply retained the appearance given it in M.E. times by AngloNorman scribes who habitually rendered the Engl. $u$ before $n$ by $o$, often adding a superfluous $e$ at the end. Camden seems to have blundered in rendering the pronunciation Clip-stone imperfectly.

Clipstone-On-the-Wolds.

See preceding name. No early forms.

Clumber.

I086 Clunbre, D.B.

I216-I307 Clumber, Testa de N.

White's Directory (1853) describes the appearance of the neighbourhood in the I8th century as follows (p. 586): "About a hundred years ago, it was one of the wildest tracts of Sherwood forest, being then 'little more than a black heath full of rabbits, having a narrow river running through it, with a small boggy close or two." Originally, the name Clumber belonged to a wood, from which it passed to the modern magnificent mansion and park of the Dukes of Newcastle now occupying its site. 
Considering the former appearance of the locality, I take the pl. n. Clumber to be the same as the independent word of identical form still found in English dialects. In the Dial. Dict., the following senses of the noun clumber (clumper) are recorded: (I) "a lump, a heavy clod of earth"; (2) pl. "shapeless blocks of stone strewn over the surface of the ground"; (3) "a clump or patch of trees, plants." The N.E.D. derives this word from O.E. clympre, "lump, mass of metal." It is very probable that the word was originally applied (in the second sense of the Dial. Dict.) to a mass of shapeless boulders whose appearance struck the early inhabitants as sufficiently singular to characterise the site.

Modern German cognates are Klumpen, "unförmliche Masse," and Klumper, "Klümpchen."

$m b$ is often written $n b$ in D.B.; see early spellings of Cromzell and Lambcote.

Coates.

I 316 Cotes, F.A.

"The dwellings, houses, or huts." The O.E. singular was cot, "a house, cottage."

CoDdington.

I086 Cotintone, D.B.
I 175 Cotintona, Woll. MSS.
I 316 Codington, F.A.

There exist in O.E. the pers. ns. Cotta and Codda, and it is very difficult to say which of the two is really contained in the above $\mathrm{pl}$. $\mathrm{n}$. The two older spellings seem to point to the former, the third to the latter. It is also possible that the original $t t$ became voiced under the influence of the surrounding vowels, a process that might have been assisted by the presence of another $t$ causing dissimilation.

It is equally questionable whether the ing is the result of the pers. n. having originally appeared in the patronymic or in the gen. sg. However, as all the old forms contain the vowel $i$, the former was most probably the case. 
Collingham.

I086 Colingeham, D.B.

I 89 Collingeham, P.R.

I 284 Colingham, F.A.

"The home or village of the Collings." The pers. n. Coll, $\operatorname{Col}(l) a$ etc. is comparatively frequent in late O.E. records. Dr Björkman is of opinion that it came from Scandinavia.

The same patronymic seems to occur in the continental pl. n., O.H.G. Collinchova (Förstemann, II).

COLSTON-BASSET [kousn, or less frequently koulsn].

ro86 Coleton, D.B.

I 160 Colestun, Index.

I 302 Colston Basset, F.A.

"The tīn or farm of Col." See Car Colston. Basset is the name of a noble family that once held land in this place; see Bassetlaw.

CoLwICK [kolik].

$$
\text { I086 }\left\{\begin{array}{l}
\text { Colewic } \\
\text { Colewi } \\
\text { Colui }
\end{array}\right\} \text { D.B. }
$$

I 225 Colewic, Bor. Rec.

The first element of this name is undoubtedly the pers. $n$. Col, which also occurs in Colston (q.v.). What the second part means, it is difficult to say for certain. If the first element is of Scand. origin, as Dr Björkman assumes, the second may be expected to be derived from the same source. In that case, -wick would go back to the O.N. vikk, "creek, bay," and "Col's creek" would be the interpretation of the modern pl. $n$.

There also exists, in the English language, the word wick, "farmstead village." It goes back to O.E. wic, "dwelling-place, village," but is found in that form in the Northumbrian dialects only, the Southern and Midland type being wich (in pl.ns. only), with the $c(k)$ fronted. (See Bülbring, $\$ 496$.$) Cp. Papplewick.$ If the O.E. wic occurred in this county it would have the latter form unless it could be proved that it was imported from north of the Humber. 
Cossal.

$$
\begin{aligned}
& \left.\begin{array}{l}
1086 \text { Coteshale, D.B. } \\
\text { c. } 1200 \text { Cozale, Woll. MSS. } \\
\text { r284 Gossale } \\
\text { r } 302 \text { Cossale }
\end{array}\right\} \text { F.A. }
\end{aligned}
$$

"The healh or valley of Cot(ta)." The $z$ in the Woll. MSS. spelling stands for $t s$ according to Norman-French practice. ts has become $s s$ through assimilation. The change from initial $c$ to $g$ in the first F.A. form is by no means an isolated one; cp. the spelling of Cotgrave in D.B.

COSTOCK or CORTLINGSTOCK.

$$
\begin{aligned}
& \text { 1086 } \left.\begin{array}{l}
\text { Cortingestoche } \\
\text { Cotingestoche }
\end{array}\right\} \text { D.B. } \\
& \text { 1 } 66-7 \text { Cordingestoch, P.R. } \\
& \text { 1 } 302 \text { Cortelingstocke, F.A. } \\
& \text { 1 } 535 \text { Cortelyngstoke, Valor Eccl. } \\
& \text { 1637 Corthigstoke, Map in Camden. }
\end{aligned}
$$

"The dwelling-place or village of the Cortlings," O.E. Cortlinga stoc. For the exact meaning of stoc see List of Elements. The pers. n. Cortel is not recorded in any of the collections of names. It must, however, have existed. The O.E. Cyrtel is found in the Crawford Charters (p. 52), and the editors have added further instances of pl. ns. containing it. See also Skeat, Pl. Ns. of Cambridgeshire, s.v. Kirtling. I take both names to be derived from an older ${ }^{*}$ Curt (cp. Crotus, Crotilo, Werle, Index), by means of the diminutive suffix $i l, a l$; the addition of $i l$ produced Cyrtel, whereas Cortal gave rise to Cortel. On the continent, the same pers. $n$. seems to be contained in the Low German Krotillandorf (Förstemann, II). The varying position of $r$ is easily explained, as metathesis in pers. ns. is not infrequent.

The name Curt may be identical with the Germ. adjective kurz. The surname Körtzel is found in modern German.

Cotgrave.

$$
\text { Type } I \text {. }
$$

I086 Godegrave, D.B.

I 157 Cottegaua.

$\left.\begin{array}{l}\text { I 230 } \\ \text { I 284 }\end{array}\right\}$ Cotegrave $\left\{\begin{array}{l}\text { Bodl. Ch. and R. } \\ \text { F.A. }\end{array}\right.$ 


\section{Type II.}

? Cotesgrafe $\left\{\begin{array}{c}\text { Reg. Lenton Abbey, quoted } \\ \text { by Thoroton, I. I66. }\end{array}\right.$

"At the grave of $\operatorname{Cot}(t a)$, O.E. at Cottan (Type I) or Cottes (Type II) grafe."

Cotham.

$$
\begin{aligned}
& \text { I086 }\left\{\begin{array}{l}
\text { Cotun } \\
\text { Cotes }
\end{array}\right\} \text { D.B. } \\
& \text { I } 302 \text { Cotum, F.A. }
\end{aligned}
$$

"At the dwelling-houses or cottages." The D.B. spellings represent the O.E. dat. pl. and nom. pl. respectively. The former survived (from O.E. at cotım), the final $m$ being later taken to stand for-ham, -home, as usual. Cp. Coates, Cottam.

Cottam (under Leverton).

$$
1302 \text { Cotum, F.A. }
$$

The same as Cotham, without the erroneous etymological spelling, as far as the additional $h$ is concerned.

CROMWell [kraməl, but usually kromwəl].

$$
\begin{aligned}
& \text { I086 Crunwelle, D.B. } \\
& \left.\begin{array}{l}
1278 \\
1302 \\
1637
\end{array}\right\} \text { Crumwell }\left\{\begin{array}{l}
\text { H.R. } \\
\text { F.A. } \\
\text { Mạp in Camden. }
\end{array}\right.
\end{aligned}
$$

"At the winding brook," O.E. at crumb (um) welle. From O.E. crumb, "winding, crooked," and well, "a brook." The development of sounds is well in accord with the general rules. The original, and natural pronunciation of this $\mathrm{pl} . \mathrm{n}$. is hardly known outside the immediate neighbourhood. In Ireland, however, the Protector is still called [kraməl], which seems to prove that hatred has a better memory than love or admiration. Or does it merely show that the Irish have not yet come under the spell of the printed word to the same extent as their English brethren? 
Cropwell Bishop, and Cropwell Butler.

I086 $\left\{\begin{array}{l}\text { Crophille } \\ \text { Crophelle }\end{array}\right\}$ D.B.

1216-72 Cropil, Index.

(a) I316 Croppehull Episcopi, F.A.

I336 Crophull Bisshop, Index.

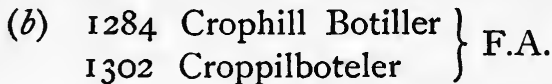

I 368 Crophull Botiler, Index.

c. I 500 Cropwell, Inq. P.M. c. I500.

"At the hump-shaped hill." The first element is the Scand. kroppr, "a hump or bunch" (Vigf.); it occurs in pl. ns. found in the Landnama Bok. The modern, spelling is due to confusion with zell, which undoubtedly was assisted by the development of a labial glide after the $p$ when the $h$ had been lost. The additions explain themselves: the Archbishop of York and the noble family of Butler were at one time the respective owners of the two villages.

Thoroton gives the correct etymology of this name when he says (I, I89) that they (viz. C.-Bishop and C.-Butler) were so named "from a round Hill which is between them, now called Hou-Hill."

CuCKNey.

\section{Type $I$.}

I086 Cuchenai, D.B.

I 200 Cucheneia, Bodl. Ch. and R.

I 278 Cuckenay, H.R.

I 302 Cockeney, F.A.

I 329 Kukeney, Index.

$$
\text { Type II. }
$$

I250 (Richard de) Kukeney (in)

Kuyekeney, Bodl. Ch. and R.

"At the quick, running water, or brook." There must have been two O.E. alternative forms of this name: at cucan éze (Type I) and at czwican éze (Type II), cucu being a variant of 
cwicu, "quick, alive." (See Bülbring, § 464.) With this name we may compare the Low German Quickborn, and the O.H.G. kecprunno, "lebendiges Wasser, Quelle," in the poem of Christ and the Samaritan Woman (I4: "uuâr maht thû guot man, neman quecprunnan?" The Vulgate has: "unde ergo habes aquam vivam ?" St John iv. II).

The second element is O.E. $\bar{e} z^{e}$, "water, river, stream."

DALBY (brook near Hickling).

DALINGTON [dælintn].

$$
\left.\begin{array}{l}
\text { Io86 Dallingtune, D.B. } \\
\text { I I } 55 \\
\text { I } 56 \\
\text { I } 57
\end{array}\right\} \text { Derlintun, P.R. }
$$

"The tün or farmstead of the Dēorlings." The D.B. form shows assimilation of $r l$ to $l l$ which is quite in accordance with the almost universal practice of its compilers. On the other hand, it is surprising to find $a(r)$ for er so early as the date of D.B. The phonetic development of erl is treated in the Phonology (\$7).

DANETHORPE.

I086 Dordentorp, D.B.

I637 Dernthorp, Map in Camden.

$$
?\left\{\begin{array}{l}
\text { Dernethorpe } \\
\text { Dornethorp } \\
\text { Darnethorp }
\end{array}\right\} \begin{gathered}
\text { quoted by Thoroton from } \\
\text { unknown sources. }
\end{gathered}
$$

"The thorp of Deorna." In D.B., O.E. eo is represented by 0 ; the pronunciation probably was [œ], mid-front-wide-round. The O.E. prototype was Deornan borp, of which the first $n$ had become denasalised in the pronunciation of the Normans under the dissimilatory influence of the following $n$, the result being the voiced point stop, $d$. Zachrisson (pp. I 20 sqq.) has collected a number of similar changes.

The development of $\operatorname{er}(>a r,>\bar{a}>e i)$ is treated elsewhere (Phonology, §7). 
DARLTON [dāltn].

I086 Derluveton, D.B.

$\left.\begin{array}{l}\text { I } 278 \\ \text { I } 316\end{array}\right\}$ Derleton $\left\{\begin{array}{l}\text { H.R. } \\ \text { F.A. }\end{array}\right.$

1695 Darleton, Map in Camden.

"The tün or farmstead of Deorlāf." The D.B. spelling is the most reliable in this case. There existed another Déorläfestün in O.E. (Cod. Dipl. 1298), which has resulted in the modern Darliston, Staffs. The existence side by side of these two names-one with and the other without $s$-clearly demonstrates that the genitival $s$ may be absent even if the first element is a pers. $n$. following the strong declension.

DAYBRook (under Arnold).

Apparently a modern name derived from that of the brook on which the hamlet is situated. There used to be cotton mills in this neighbourhood worked by water-power. It is said that the brook was frequently stopped during the night, so that the water might accumulate for the day's work: thus the brook carried water in the daytime only. I give this somewhat singular account as it was related to me. This explanation is very doubtful.

\section{DEAN (brook near Hickling).}

This name may be of Celtic origin; there is a river Dane in Staffordshire, and another in Cheshire. Isaac Taylor (Words and Places, ch. IX) enumerates a large number of river-names containing a similar element found in various parts of Europe formerly occupied by Celts.

Devon (river) [dīnn].

$$
\text { I680 Devon, Index. }
$$

A Celtic river-name; see Dean.

DOVER BECK.

1225 Doverbec, Bor. Rec.

This name is a tautology. The first part is of Celtic origin, having a common ancestor with modern Welsh dwor, drefr, "water." When the original meaning was lost, an explanatory superfluous beck, from Scandinavian bekk(r), "brook," was added. 


\section{DRAKEHOLES.}

This small hamlet, of which no early forms are available, is situated "in a narrow part of the hills through which the Chesterfield canal passes by means of a tunnel." The meaning may be: "the holes of the dragon, or dragons," O.E. dracan, or dracena hol(as). Cp. Low German Drakenloch, a small valley leading out of the Urpetal (Jellinghaus, p. vi).

Drayton (East and West).

$$
\begin{aligned}
& \text { I086 }\left\{\begin{array}{l}
\text { Draitone } \\
\text { Draitun }
\end{array}\right\} \text { D.B. } \\
& \text { I3 I6 }\left\{\begin{array}{l}
\text { Est } \\
\text { West }
\end{array}\right\} \text { Drayton, F.A. }
\end{aligned}
$$

"The hidden tīn or farmstead." There exist numerous Draytons all over the country. Prof. Skeat (Pl. Ns. Cambs. p. 9) was the first to explain their etymology. He compares the element $d r a i$ with a squirrel's $d r a y$, which he says is derived from an O.E. draz with the wider sense of "retreat, hidingplace."

The appearance of the modern village of West Drayton seems to bear out the suggested etymology. West Drayton is situated in low-lying, boggy country, surrounded on all sides by distant hills. It is not discovered by the traveller until he has come close upon it. When dwellings were low and brushwood and trees more plentiful, the seclusion of the spot must have been still more apparent. East Drayton, however, is quite open.

DRINSEY NOOK.

The "Nook" is a slight projection of dry land among meadows subject to floods. It was an island before that part of the country was drained. In the absence of early spellings one can only guess at the meaning. I take it to have been O.E. Drenges ēze, "Dreng's island." The word Dreng is used both as a pers. n., and an appellative. The latter, which is the original of the pers. n., comes from Scandinavian and designates members of that class sometimes spoken of as rädcnihtas in O.E. literature (Pl. Ns. of the W. Rid. p. xxiii). They were the successors of the old be 3 nas, "retainers of a chief, noblemen," principally employed in warfare. Above the ceorl (see Carlton) 
in station they often enjoyed the privileges of the mediæval nobility (see Vinogradoff, Growth of the Manor, p. 220; Engl. Society in the I Ith Cent. p. 62).

It is doubtful whether the word is used in the first or second sense here. The West Riding pl. n. Dringhouses, older Drengehous, most probably contains the appellative in the plural : drenga hüs, "the houses of the soldiers or noblemen."

ey $>$ in according to rule; the form Dring is found in M.E. (Phonology, §6). ys $>n s$ through assimilation (Phonology, § I3).

\section{DUNHAM-ON-TRENT.}

$$
\begin{aligned}
& \text { I086 Duneham, D.B. } \\
& \text { I } 55 \text { Dunehā, P.R. } \\
& \text { I } 3 \text { I6 Dunham, F.A. }
\end{aligned}
$$

The second element of this name is undoubtedly O.E. hãm, "home, homestead, village." The first may be either O.E. dūn, "hill, mountain," or the genitive of the pers. n. Dun $(a)$. The place being situated on a gentle eminence, the former alternative may be taken as the most likely interpretation. Thus the meaning would be "the village on the hill."

It has been suggested that this place derives its name from the "dunes," i.e. hills of blown sand found in the neighbourhood. This is impossible, as the word dune meaning "a low sand-hill" is of comparatively recent introduction, having come into the English language through the medium of French speech. The N.E.D. gives I 2 I 3 as the first date of its occurrence.

\section{DUNSELL-IN-TEVERSAL.}

There are no early forms. It may be derived from O.E. dün seld or setl (Bülbring, $§ 444$ ), "the dwelling on the down or hill." But this is a mere guess for which there is no reliable evidence. However, the farmhouse bearing this name is actually situated on a hill.

EAKRING.

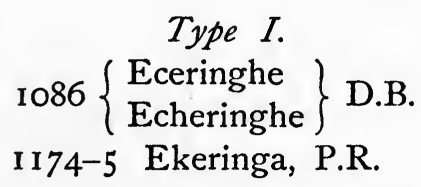




\section{Type II.}

I637 Akringe, Map in Camden.

I704 Akring, Map I704.

Type IIII.

$\left.\begin{array}{ll}\text { I } 156 & \text { Eikeringe } \\ \text { I } 200 & \text { Eigring }\end{array}\right\}$ Index.

I 278 Aykering, H.R.

I29I $\left\{\begin{array}{l}\text { Eycring } \\ \text { Eykringk }\end{array}\right\}$ Tax. Eccles.

$\left.\begin{array}{ll}\text { I } 302 & \text { Eykring } \\ \text { I428 } & \text { Aykering }\end{array}\right\}$ F.A.

In spite of the numerous early spellings it is impossible to explain the etymology of this name with any degree of certainty. I take it to have been a patronymic family name in the gen. pl. followed by some such word as hām or tiin. It may have been Eädrwaceringa hãm, "the home of the descendants of Eädwacer." This very long name would most certainly be shortened and its pronunciation might have been simplified at a very early period, through the following stages: éadceringa $>$ éaceringe ( $>$ modern Eakring), or acringe ( $>$ Type II), or with later shortening of the initial vowel, ecringe (> Type I).

The forms quoted as Type III I take to be due to popular etymology. The pl. n. was explained as eikar ing, "the meadow of the oaks," and I am told that this interpretation fits the locality very well. eikar is the Scand. gen. pl. of $e i k$, "oak tree," ing the M.E. form of eng, "meadow," derived from the same language (see Pl. Ns. of the West Rid. p. xl).

EASTWOOD.

\section{Type $I$.}

I 166-7 E.st Twait, P.R.

c. I $200\left\{\begin{array}{l}\text { Estweit } \\ \text { Hestweit }\end{array}\right\}$ Woll. MSS.

I 225 Estwaite, Bor. Rec.

$\left.\begin{array}{r}\text { I 227-77 } \\ \text { I } 316\end{array}\right\}$ Estweyt $\left\{\begin{array}{l}\text { Non. Inq. } \\ \text { F.A. }\end{array}\right.$

1483 Estwyt

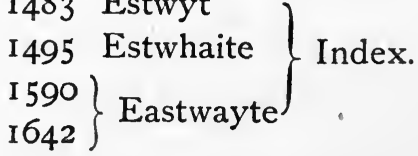




\section{Type II.}

? (Eswaicte or) Eastwood, Thoroton, II, 236.

Type III.

I086 Estewic, D.B.

"The thwaite or outlying farm in the East." The second element is of Scandinavian origin: O.N. pveit, "piece of land, paddock, parcel of land ; originally used of an outlying cottage with its paddock." As it is of very rare occurrence in this county, it was replaced by the more familiar wood (Type II).

The D.B. form is due to a misreading of $c$ for $t$, these two letters being frequently interchanged on account of graphic resemblance.

EATON.

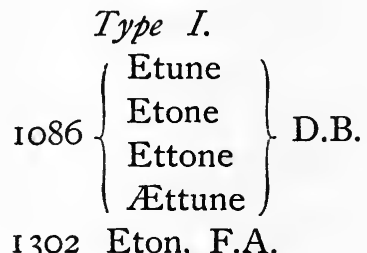

Type II.

(Eaton or) Idleton, White, Directory, I 853.

"The tīn or farmstead by the river (Idle)." The O.E. prototype seems to have been: idel $\bar{e} a$ tīn, "the farm by the brilliant river" (see Idle, p. 72). The distinctive addition to the river could be left out, as it was certainly known in the neighbourhood as séo éa, "the river," pure and simple.

EDINGLEY [edipli].

1302 Edingley, F.A.

1637 Heddingley, Map in Camden.

"The leak or field of the sons of Eda, or of Eada, or of Eädzin." Both O.E. Edinga lēah and Edanlēah, as well as Eädroin(es) lêah, might result in the modern form.

Camden's spelling proves that the $e$ was pronounced short; the initial $h$ means nothing. 
EDWALton [edw'ōltn, edltn].

$$
\begin{array}{ll} 
& \\
\text { I } 3026 & \text { Edwoltun, D.B. }
\end{array}
$$

"The tün or farm of Eädweald." The absence of the genitival $s$ is noteworthy. Of the two pronunciations recorded, the second is the only natural one. The shortening of the initial vowel (before $d w$ ) and the subsequent loss of $w$ beginning an unstressed syllable are in accordance with well established rules.

EDwinstowe or Edwinstow or Edenstowe (Edensta, Hope).

\section{Type 1 .}

I086 Edenestou, D.B.

I 278 Edenstow, H.R.

I428 Ednestowe, F.A.

$\left.\begin{array}{r}\text { c. I } 500 \\ \text { I637 }\end{array}\right\}$ Edenstow $\left\{\begin{array}{l}\text { Inq. P.M. c. I } 500 . \\ \text { Map in Camden. }\end{array}\right.$

Type II.

c. 1500 Eddingstow, Inq. P.M. c. I 500.

It is very strange that the old spellings do not contain a $w$ in a single instance. The etymology seems to be: "The stōw or place of Eädwine." It is said that King Edwin's body was brought to Edwinstowe after the battle of Heathfield, A.D. 633 , "and from what we know of this obscure period it does not seem unlikely that such may have been the case" (Guilford, p. 84). This view is confirmed by the meaning of the suffix störe, "a holy place, sanctuary, sepulchre." In the present name it may have designated the burial-place of the king. See Middendorf on stōw, and cp. Broxtow.

Type II shows an interesting development of unstressed (w)in, on which see Alexander, The Suffix ing.

EGMANTON [egmontn].

$$
\left.\begin{array}{l}
\text { I086 Agemuntone, D.B. } \\
\text { I278 } \\
\text { I } 302
\end{array}\right\} \text { Egmanton }\left\{\begin{array}{l}
\text { H.R. } \\
\text { F.A. }
\end{array}\right.
$$

"The tün or farm of $\dot{E} \dot{c} \dot{g} m u n d . " \quad$ The O.E. $\dot{g}$ should result in modern $d g$ (*Edgmanton). The present form is either a 
mere spelling, or the fronted $\dot{g}$ has been changed to the backstop under Scandinavian influence.

The development of the unstressed $u$ is interesting: $u>0>a>0$.

ELKESLEY [locally: el(k)sli ; otherwise : elkəsli].

$$
\begin{aligned}
& 1086\left\{\begin{array}{l}
\text { Elchesleig } \\
\text { Elchesleie } \\
\text { Elcheslie }
\end{array}\right\} \text { D.B. } \\
& \text { I } 278 \text { Elkesle, H.R. } \\
& \text { I } 316 \text { Elkesley, F.A. } \\
& \text { c. I } 500\left\{\begin{array}{l}
\text { Ellersley } \\
\text { Elkesley } \\
\text { Elsley }
\end{array}\right\} \text { Inq. P.M. c. I } 500 .
\end{aligned}
$$

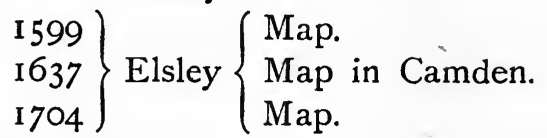

Probably: "the léah or field of Ealc." This pers. n. is not recorded in the Onomasticon; we find, however, Ealac. It must be the abbreviated form of a full name beginning with Ealh-, Ealc-. If the first spelling taken from the Inq. P.M. is not merely an erroneous one, the original pers. $n$. involved would have been either Ealhheard or Ealhhere, both of which are remarkably frequent in O.E. That a very primitive form of a pl. n. should be employed by a writer about the year I 500 is not so improbable as it would seem at first sight; for he may have been drawing from local documents of great antiquity, which are now lost.

On the name Ealc see Staffs. Pl. Ns., s.v. Elkstone.

ELSTON.

$$
\text { Type I. }
$$

I086 Elvestune, D.B.

Type II.

1302 Eyliston, F.A.

It is difficult to give the etymology of this name on account of the scarcity of early spellings. The most probable derivation seems to be from Eilafes tün, "the farmstead of Eilaf." This 
assumption would at once explain the $v$ in Type I and the ey in Type II. The pers. $n$. involved is Scandinavian in origin. (See Björkman, s.v.)

EltoN.

$$
\begin{aligned}
& \text { I086 Ailtone, D.B. } \\
& \text { I } 284 \text { Elton, F.A. }
\end{aligned}
$$

"The tīn or farm of $A_{3}$ el." This pers. n. is a late, probably Norman variant of the older EEdel. The relation between the two has been fully discussed by Dr Zachrisson (pp. Ioo sqq.).

EPPERSTON.

$$
\begin{aligned}
& \text { I086 }\left\{\begin{array}{l}
\text { Eprestone } \\
\text { Epstone }
\end{array}\right\} \text { D.B. } \\
& \left.\begin{array}{l}
\text { I } 225 \\
\text { I } 302
\end{array}\right\} \text { Epreston }\left\{\begin{array}{l}
\text { Bor. Rec. } \\
\text { F.A. }
\end{array}\right.
\end{aligned}
$$

"The tün or farm of *Eopeorht." This pers. n. is not recorded in the Onomasticon. It may, however, be safely assumed to have existed as the corresponding continental form Eoberht exists (Förstemann, I). It is derived from eoh-berht, which explains the $p$ in the English type : this arose out of the $b$ through the unvoicing influence of the preceding $h$ which disappeared. Cp. Scotch neeper, "neighbour," from O.E. nēahgebür, which exhibits a similar change.

EREWASH (river).

$$
\begin{aligned}
& \text { c. II75 Yrewis, Woll. MSS. } \\
& \text { I637 }\left\{\begin{array}{l}
\text { Erewash, Camden, p. } 550 . \\
\text { Arwash, Map in Camden. }
\end{array}\right.
\end{aligned}
$$

The termination is identical with the modern dialect word wash, "any shore or piece of land covered at times by water; a mere ; an inundation" (Dial. Dict.), which is also the name of the well-known arm of the sea between Norfolk and Lincoln, the Wash. The word is, no doubt, connected with the root contained in to wash and water.

The first element may be a pre-English river-name $* I r$ - $* E r$-, which seems to be contained in the Lancashire Irwell. But this is very doubtful. 
EvERTON.

$$
\begin{array}{ll}
\text { I086 Evretone, D.B. } \\
\text { I I89 Everton, P.R. }
\end{array}
$$

"The tiun or farmstead of Eofer." Note the absence of the genitival s. The O.E. pers. n. Eofer and its compounds are comparatively frequent.

FARNDON.

$\left.\begin{array}{ll}\text { Type I. } \\ \text { I316 } & \text { Farnedón } \\ \text { I402 } & \text { Ferndon } \\ \text { Type II. F.A. } \\ \text { I086 } & \text { Farendune, D.B. } \\ \text { I392 } & \text { Farendon } \\ \text { I543 } & \text { Farunden } \\ \text { I586 } & \text { Faringdon }\end{array}\right\}$ Index.

\section{Type III.}

I637 Farmdon, Map in Camden.

In spite of Type II, I take this name to be derived from O.E. fearn dīn, "fern-covered hill." Type I represents the original form without any unusual alteration, er being merely a spelling of $a r$ into which both M.E. ar and er had developed. As to Type II, I assume that a vowel-glide arose between the $r$ and $n$ which is represented by various symbols. Farendun then developed into Faringdon (I 586), a change which has been discussed on another page (Phonology, § I 3 ).

Camden's spelling is either a blunder or shows that the $n$ had become assimilated to the initial $f$. See Phonology, $§$ I 3 .

FARNSFIELD.

$$
\text { Type } I \text {. }
$$

I 89 Farnefeld, P.R.

I637 Farnfelde, Map in Camden.

Type II.

I086 $\left\{\begin{array}{l}\text { Farnesfeld } \\ \text { Franesfeld }\end{array}\right\}$ D.B.

I33I Farnesfeld, Index. 
Type II seems to imply a pers. n. (O.E. Frena, with metathesis?) as the first element on account of the genitival $s$. However, I give preference to Type I, explaining the name as O.E. fearnfeld, "the open space, or plain covered with fern." The $s$ was introduced on the mistaken notion, derived from analogy, that the first element was a pers. 'n. Dr Zachrisson gives numerous instances of a similar "loose" or inorganic $s$ (pp. I I 8 sqq.).

FELLEY.

I 240 Felley, Bor. Rec.

This may stand for O.E. feld lèah, dat. feld lèaze, "the open field," or "the field in the plain." The place is situated partly on a lofty eminence, and it seems probable that the name originally referred to the lower part of the locality. The disappearance of $d$ between the l's is natural.

The view expressed above might be confirmed by the fact that there existed an exactly similar name in FrieslandVeldlagi, quoted by Förstemann (II).

Fenton.

$$
\begin{aligned}
& \text { I086 } \left.\begin{array}{l}
\text { Fentune } \\
\text { Fentone }
\end{array}\right\} \text { D.B. } \\
& \text { I3 I6 Fenton, F.A. }
\end{aligned}
$$

Considering the geographical position of this place, there can be no doubt as to its etymology. "The farm in the fen," from O.E. fenn, "mud, dirt, fen." The country is drained now.

Finningley (Finlah, Hope).

$$
\text { Type } I \text {. }
$$

I086 Feniglei, D.B.

I428 Fenyngley, F.A.

$$
\text { Type II. }
$$

I 278 Finningelay, H.R.

$\left.\begin{array}{ll}\text { I } 302 & \text { Finningley } \\ \text { I } 316 & \text { Fynyngeleye }\end{array}\right\}$ F.A.

Two explanations of this name are possible according to which type is considered original. 
(I) "The leah or field of the Finnings, the sons of Finn." This pers. $n$. is of Scandinavian origin, and always borne by Norsemen, either in history or fiction. A family of the same patronymic is found in Southern Germany: Finninga quoted by Förstemann (II).

(2) I am myself inclined to believe that Type I represents the original name more truly than Type II which is derived from the former. O.E. fenninga tün, "the farm of the dwellers in the fen," is a most appropriate name for the locality situated in the old marshes. The suffix -ing was used in Germanic to derive the name of a tribe from the locality they inhabited. The best known examples of this usage are the designations of the two nations into which the Goths were divided ${ }^{1}$. The Ostrogothi were called-in Latin garb-Greutingi, because they inhabited sandy plains (cp. O.E. grēot, "sand"), whereas the Visigothi were known as Tervingi, because they lived in a country covered with woods (cp. O.E. trêoze, "tree"). An O.E. example of a corresponding derivation (of which there are many more) is quoted from a charter by Dr Middendorf, s.v. heeah: hēantunninga gemēere.

The transition from $e$ to $i$ before $n$ is not without parallel in the English dialects. Instances of such a change are quoted in the Dial. Grammar, §55. See also Horn, § 38 .

FISKERTON.

\section{Type I.}

1086 Fiscartune, D.B.

1278 Fiskerton, H.R.

I316 Fyskerton, F.A.

Type II.

1278 Fiskiston, H.R.

"The tīn or farm-house of the fisherman, or fishermen." The O.E. original was either fiscera tün (gen. pl., Type I), or fisceres tün (gen. sg., Type II). In the ordinary course, the O.E. $s c$ should be represented by $s h$ in the M.E. and modern forms.

1 Zeuss, Die Deutschen und ihre Nachbarstämme. München, I837. 
The sk is explained by assuming influence of Scand. fiskr, "fish," which may also have been used as a pers. $n$.

To this very day this village is a favourite resort for fishermen.

FLAWBOROUGH.

$$
\text { Type } I \text {. }
$$

I086 Flodberge, D.B.

\section{Type II.}

I316 Flaubergh, F.A.

The second element is the O.E. beorg, "mountain, hill, mount," the modern spelling of which has been influenced by the more frequent borough, the representative of O.E. burh. This part of the name is explained by the fact that the little village is situated on a hill.

I can make nothing of the first element, which appears in two strange spellings.

FLAWFORD (under Ruddington).

There are no early forms. The first element seems to be identical with that contained in the preceding pl. n.

Fledborough.

$$
\begin{array}{ll}
\text { I086 } & \text { Fladeburg, D.B. } \\
\text { I } 278 & \text { Fleburg, H.R. } \\
\text { I } 302 & \text { Fledburgh, F.A. }
\end{array}
$$

"The burh or fortified place of Flêeda." An O.E. Flädanburg, which might have been the ancestor of the modern name, is recorded in a charter (Cart. Sax. 76,238).

FLEET (river).

From O.E. flèot, "stream, channel"; the word is connected with fleotan, "to float, sail, swim." In modern H.G. we find its cognate Fliess, "small river," M.H.G. vliez. The Low German form is Fleet, from older vlèt.

Flintham.

$$
\begin{aligned}
& \text { I086 } \left.\begin{array}{l}
\text { Flintham } \\
\text { Flinteham }
\end{array}\right\} \text { D.B. } \\
& \text { 1284 Flintham, F.A. }
\end{aligned}
$$


From O.E. flint, " rock," and häm, "home, habitation, village." It is difficult to say what is the exact sense intended to be conveyed by the composition of these two elements. It might have been the "house in the rock, or by the rock, or built of rock" etc.

\section{Fulwood.}

Although there are no early forms, the etymology of this name is quite clear. The O.E. ancestor is fül wudu, "the foul, dirty, boggy wood." Before the combination lw, the $\bar{u}$ was shortened, whereas in the independent word, foul, it remained long and was diphthongised.

Gamston (near West Bridgford).

1086 Gamelestune, D.B.

1302 Gameleston, F.A.

GamstoN (near East Retford).

I086 Gamelestune, D.B.

I 278 Gameleston, H.R.

"The tün or farmstead of Gamal." The D.B. forms preserve the O.E. appearance of this name almost completely. The pers. n. is of Scandinavian origin.

GATEFORD.

\section{Type 1 .}

I 278 Gaytford, H.R.

c. 1500 Gaytforth, Inq. P.M. c. I 500 .

\section{Type II.}

c. I 500 Gatford, Inq. P.M. c. I 500.

"The goat ford." From O.E. gätaford, which, with the $\bar{a}$ shortened at an early period before the combination $t f$, resulted in Type II. The other type preserved in the modern spelling exhibits the influence of Scand. geit, "goat." See Björkma n, Scand. Loanwords, p. 42. The th instead of $d$ also points to Scandinavian origin; cp. O.N. fjortr.

Fords are often named after the animals that passed through them, as Oxford, Swinford, Hertford. 
There is a Gateforth in the West Riding wholly Scandinavian in appearance. Dr Moorman interprets it as "the ford of the goats." The same name is borne by a place in O.H. German territory, Geizefurt in Hesse (Förstemann, II).

GEDLING.

\section{Type $I$.}

I086 Ghellinge, D.B.

I278 Gedling, Kedling, H.R.

$\left.\begin{array}{ll}\text { I } 302 & \text { Gedling } \\ \text { I } 346 & \text { Godeling }\end{array}\right\}$ F.A.

Type II.

I 89 Gedlinges, P.R.

Type III.

I637 Gadling; Map in Camden.

I take this name to be derived from O.E. on gadelingum, "among the companions in arms" (Type I). The nominative plural gadlingas is the ancestor of Type II. Camden's a (Type III) goes back to O.E. $\mathscr{e}$, whereas the other forms contain $e$ which most probably is due to a kind of secondary $i$-mutation (see gadeling in Sievers and Bülbring, Indices). In M.E. both gedeling and gadeling are found (N.E.D.).

Gilling in Yorks. apparently has the same origin; it occurs as in (on) Getlingum, in Gatlingum in Bede (Miller, O.E. Bede, p. 43). On the continent are found O. Low Germ. Getilingthorp and O.H.G. Gellingin, modern Göllingen near Sondershausen (Förstemann, II).

Gibsmere.

I086 Gipesmare, D.B.

I 302 Gyppesmere, F.A.

The second element is O.E. mere, "lake, pool." In the D.B. form, the $a$ is due to the influence of Scand. mar, "the sea." This substitution of mare for mere in D.B. is particularly noticeable in Yorks. pl. ns. (See Stolze, § 7, anm. 3; Jellinghaus, p. 307.)

The first element seems to be a pers. $n$. It may be identical with the one contained in O.E. Gypeswic, modern Ipswich (Cod. 
Dipl., Index). The initial $g$ of the O.E. name must have been fronted, so that the $y$ cannot but represent an original West Germanic palatal vowel ; otherwise the disappearance of the initial $g$ in Ipswich could not be explained. The unfronting of this sound in the Notts. pl. n. seems to be due to Scandinavian influence which has also been at work in the second element. The meaning is "Gippes pool." The pers. n. involved is not recorded in the Onomasticon. It may be contained in the Norwegian pl. $\mathrm{n}$. Gipsen discussed by Rygh (N. Gaardnavne, p. 345).

The combination $p s$ was changed to $b z$ under the influence of the surrounding voiced sounds.

\section{GiltbRoOK (under Greasley).}

In the absence of early spellings nothing definite can be said about this name. It may stand for O.E. gylden brōc, " the golden, i.e. yellow brook." The first element may have been influenced by the adjective gilt. Similar river-names occur on the continent; O.H.G. Goldaha, O. Low Germ. Goldbiki, O.H.G. Goldgieze are enumerated by Förstemann (II).

GirToN.

$$
\left.\begin{array}{l}
\text { I086 Gretone, D.B. } \\
\text { I278 } \\
\text { I291 } \\
\text { I } 16
\end{array}\right\} \text { Gretton }\left\{\begin{array}{l}
\text { H.R. } \\
\text { Tax. Eccl. } \\
\text { F.A. } \\
\text { I704 Girton, Map. }
\end{array}\right.
$$

"The tīn or farmstead in the sand," O.E. greot tün. The country round Girton is very marshy and sandy in places, and both to the north and south of the village considerable dunes have been formed by the drift sand from the Trent. O.E. greot means "sand, rubble," and is identical with O.H.G. grioz, modern Germ. Gries. The Hessian pl. n. Griesheim has the same meaning as Girton.

The phonetic development is quite regular: M.E. $\bar{e}<\bar{e} o$ is shortened before $t t$; metathesis of $r$ is characteristic of the dialect (Phonology, § I5); the modern spelling ir represents the sound into which er had developed. 
Glapton.

I I6-72 Glapton, Cal. Inq. P.M. I.

Probably from O.E. Glappan tīn, "the farmstead of Glappa." The pers. $n$. is found in O.E., and also in O.H.G. as Claffo, Clapho etc. (Förstemann, I) ; or possibly the Scand. name Clapa, traced as occurring in England by Dr Björkman, may be contained in this pl. $n$.

Gleadthorpe Grange (under Worksop) [gledpj̄p].

I086 Gletorp, D.B.

I 278 Gledetorp, H.R.

I853 Gledthorpe, White's Directory, p. vi.

It has been suggested that the first element is O.E. glēed, "bright, clear, glad"; the second is Scand. porp, "village, hamlet." The meaning would be "the bright, pleasant hamlet."

It is, however, very doubtful whether the variant *glēed, containing a long vowel, ever existed. It is said to occur in poetic texts, and might be represented in M.E. by the spelling glead (N.E.D., s.v. glad). I prefer to leave the etymology of the first element doubtful, and would refer investigators to similar names: Gleadless, Gledhow, and Gledstow Hall, all in the West Riding of Yorkshire.

GOLDTHORPE (under Hodsock).

There are no early spellings. I take this to be derived from Goldan borp, "the hamlet of Golda or Golde." Whether this pers. $\mathrm{n}$. is of O.E. or Scand. origin I am unable to say.

GonALSTON [ganəsn].

(4)

$$
\begin{aligned}
& \text { I086 }\left\{\begin{array}{l}
\text { Gunnulfestone } \\
\text { Gunnulvestune }
\end{array}\right\} \text { D.B. } \\
& \text { I278 }\left\{\begin{array}{l}
\text { Guneliston } \\
\text { Gunohston }
\end{array}\right\} \text { H.R. }
\end{aligned}
$$


$\left.\begin{array}{lll}\text { (5) } & \text { 1 } 302 & \text { Gunnolston } \\ \text { (6) } & \text { 1 } 316 & \text { Gonelston } \\ \text { (7) } & \text { 1 } 346 & \text { Gonaldeston }\end{array}\right\}$ F.A.

(8) 1637 Gumalston, Map in Camden.

O.E. Gunnulfes tīn, " the farmstead of Gunnulf." The latter is a Scandinavian man's name. No. I evidently is copied from an O.E. document with $f$ instead of the M.E. $v$. The $h$ in No. 4 and the $m$ in No. 8 are scribal blunders. The $d$ in No. 7 is due to confusion with the well-known Scand. female name Gunnhild.

The history of the unstressed vowel in the second syllable is interesting: $u>0>a>0$.

GoTHAM [goutm].

$$
\begin{aligned}
& \text { I086 Gatham, D.B. } \\
& \text { I } 52 \text { Gataham, Index. } \\
& \text { I } 316 \text { Gotham, F.A. }
\end{aligned}
$$

O.E. gāta hām, "the home of the goats, the goat village." The Index form is evidently copied from an O.E. document. Thoroton $(I, 36)$ has the following explanation : "a Dwelling or Home of Goats."

GOVERToN (under Bleasby) [gouvatn].

$$
\text { I } 302 \text { Goverton, F.A. }
$$

O.E. Gärfrið̄es tīn, "the farmstead of Gärfrið." This pers. n. is found once in an O.E. document. It is very frequent on the continent, as Gairfrid in a very primitive form, later Gêrfrid (Förstemann, I). The loss of the first of the two $r$ 's through dissimilation is natural ; so is the development of $\bar{a}$, represented by modern [ou]; cp. O.E. gāt $>$ goat.

GRANBY.

$$
\text { Type I. }
$$

1086 Granebi, D.B.

I 1302 Graneby $\}$ F.A.

Type II.

$\left.\begin{array}{l}\text { I086 } \\ \text { I } 184\end{array}\right\}$ Grenebi $\left\{\begin{array}{l}\text { D.B. } \\ \text { Index. }\end{array}\right.$ 
"The $b \bar{y}(r)$ or farm of Grani." The pers. n. forming the first element comes from the Scandinavian language; so does the ending. The spelling under Type II is due to an attempt at connecting the name with the adjective O.E. grenne, "green."

GRASSTHORPE or GREISTHORPE [grespōp].

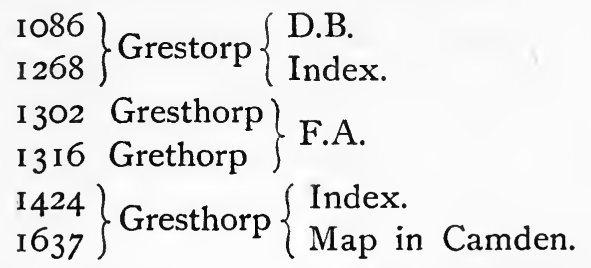

All the old spellings point to M.E. gres porp, "grass thorpe or village." The form gres is explained by Dr Björkman (Scand. Loanwords, p. 30) as due to Norse influence. This tallies with the fact that the second element too is derived from the Scandinavian.

I can make nothing of the second modern spelling: it is hardly likely that the Scandinavian male name Grīs, Grīse (Björkman, s.v.) has had any influence. The first modern form shows influence of Standard English grass, which has, however, not yet affected the local pronunciation.

GREASLEY [grīzli].

\section{Type $I$.}

I086 Griseleia, D.B.

I428 Grisseley, F.A.

$$
\text { Type II. }
$$

1 216-72 Greselley, Inq. P.M. I.

1284 Gresley

I 302 Gresseley $\}$ F.A.

I 346 Greseley

Type III.

I284 Grelley, F.A.

Type IV.

I637 Graseley, Map in Camden. 
The original meaning is preserved by Type I: "the lea h or field of Gris." The latter name of Scand. descent is treated by Dr Björkman. Type II, which seems to have survived eventually, although I cannot explain the quantity of the first vowel satisfactorily, arose out of the confusion with M.E. gres, "grass" (see Grassthorpe). Type III is derived from Type II, sl [zl] having become assimilated to $l l$. In Type IV the $e$ is replaced by $a$ on the analogy of the modern standard form grass (or graze).

\section{GREET (river).}

958 (ondlang) greotan, Cart. Sax. 1029.

The above quotation from a charter is of very questionable value, and I am inclined to set aside its evidence altogether, as far as the final $n$ is concerned. I take this name to represent O.E. grēot è $a$, or èze, "gravelly, sandy river," from O.E. grēot, "gravel, sand," and éa, éze, "water, water-course." There exists another river Greet in Worcestershire. The termination has disappeared completely as in the original river-name Blyth (q.v.).

On O.H.G. territory a corresponding formation Griezpah is found (Förstemann, II).

\section{GRIMSTON.}

$$
\begin{aligned}
& \text { I086 Grimestune, D.B. } \\
& \text { I } 302 \text { Grymeston, F.A. }
\end{aligned}
$$

From O.E. Grimes tīn, "the farm of Grim(r)." The pers. n. involved is Scandinavian in origin. The long $\bar{\imath}$ was shortened before the combination mst.

Gringley (Little) (Grinley, Hope).

$$
\begin{aligned}
& \text { Type I. } \\
& \text { (a) } 1086\left\{\begin{array}{l}
\text { Grenleige } \\
\text { Grenelei }
\end{array}\right\} \text { D.B. } \\
& \text { I } 278 \text { Grenlay }\left\{\begin{array}{l}
\text { H.R. } \\
\text { Inq. P.M. II. }
\end{array}\right. \\
& \text { I } 316 \text { Grenleye, F.A. } \\
& \text { I } 327-77 \text { Grenley, Non. Inq. }
\end{aligned}
$$


(b) I 375 Grynley, Index.

Type II.

c. I300 Gringelay, Index.

Type 111 .

1704 Little Grimley, Map.

O.E. on bēere grènan léage, "on the green field or plain." The neighbourhood is noted for its meadows. Clareborough, which derives its name from "clover," is close by.

O.E. $\bar{e}$ was shortened during the M.E. period after having been raised to $\bar{\imath}$ (Type I $b$ ). Type II arose out of confusion with the following name. The genuine etymology is preserved in the modern local pronunciation, as recorded by Hope, but not in the official spelling. The change from in to ing is remarkable; it is probably due to confusion with the following name.

The inventor of Type III fancifully connected the name with the pers. n. Grim contained in Grimston, Grimsby etc.

There is a place called Grindley in Staffordshire which has the same origin and meaning. The $d$ arose out of a phonetic glide between $n$ and $l$.

GRINGLEY-ON-THE-HILL.

\section{Type I.}

1086 Gringeleia, D.B.

c. I 200 Gringhelaya, Cal. Rot. Chart.

I278 Gringele, H.R.

I 3 I6 Gringeley, F.A.

I327-77 Gryngeley, Non. Inq.

I 372 Grynglay, Index.

\section{Type $I I$.}

I086 Greneleig (?), D.B.

I $535\left\{\begin{array}{l}\text { Greynley } \\ \text { Grenely } \\ \text { Grynley on the Hill }\end{array}\right\}$ of the Hill

Type II most probably arose out of confusion with the preceding name. As a matter of fact, it is extremely difficult, if 
not at times impossible, to distinguish between the two in early records. In the Inq. P.M. c. I500, e.g., both are hopelessly mixed up. The D.B. spelling quoted under Type II may refer to the preceding place.

I take the first element to be a variant of the O.N. pers. n. Grimketell, Grimkell, Grinkell. The existence of a type Gringel is conclusively proved by Prof. Wyld, who refers to the above pl. n. and further adduces Grimgelege and Gringelthorp (P1. Ns. of Lancs., s.v. Cringlebarrow Wood, p. 102).

It is highly interesting to trace the development of that personal name through the succeeding stages of shortenings and assimilations. First the $\bar{i}$ is shortened before the combination $m k$, and the last syllable loses its vowel: Grimketell $>$ Grimketll. Then $t$ is assimilated to $l, m$ to $k: G r i \eta k e l(l)$. After that the $k$ is voiced under the influence of the surrounding sounds; result, Gringel.

The meaning is "Grimkel's field or meadow."

GROVE.

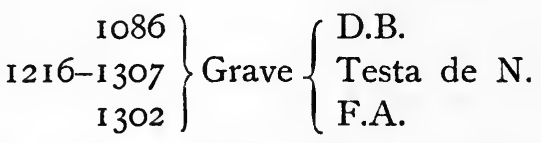

From O.E. at $b \overline{\bar{e}} m$ grāfe, "at the grove." Taking into account the modern spelling, this is the only explanation I can offer, although the very late persistence of the $a$ in the above forms might speak against that derivation, and in favour of

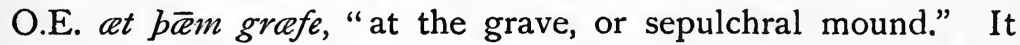
is, however, possible that this persistence is only apparent, the spelling being copied from earlier records.

GUNTHORPE [ganpōp].

$$
\text { Type } I \text {. }
$$

I086 Gulnetorp, D.B.

? Gunildethorp, Thoroton, III, 25.

$$
\text { Type II. }
$$

1086 Gunnetorp, D.B.

1278 Guntorp, H.R.

I3O2 Gunthorp, F.A.

1489 Gownthorpe, Woll. MSS. 
If the spelling quoted by Thoroton as an ancient one is really genuine and was, as is not unlikely, taken by him from old local records, the etymology of the name is clear : Gunnhildar borp, "the village of Gunhildr." The latter is a feminine pers. n., Norse in origin, and rather frequent in M.E. times. It is very rare that places are called after women. The D.B. spelling under Type I may very well be an attempt at representing a pronunciation * Gunelthorp $<$ Gunildarborp. It is just what one would expect the compiler of D.B. to do. The havoc played by Anglo-Norman scribes among the liquids and nasals of English place-names is well illustrated by numerous examples collected in Dr Zachrisson's book (pp. I 20 sqq.). Metathesis of $d l(>l d)$ is found in several instances in D.B. (Stolze, $\S 30$ ).

If the above explanation of Type I is accepted, Type II is but a further shortening of the original. If it is rejected as based upon doubtful or spurious evidence, the name may be taken to contain as first element the $\mathrm{ON}$. masculine pers. n. Gunner.

It may be mentioned here that the occurrence of Gunhild in a pl. n. is better attested for the Yorks. Gunthwaite, which is spelt Gunnyldthwayt in a document of 1389 (Descriptive Catalogue of Ancient Deeds, I, Index).

HABBLESTHORPE, see APPESTHORPE.

HAGGONFIELD (under Worksop).

The absence of early spellings makes it impossible to suggest an etymology with any degree of certainty.

HALlam [heiləm].

$$
\begin{aligned}
& \left.\begin{array}{ll}
\text { I 33I Halumi } \\
\text { I 54I } & \text { Halom }
\end{array}\right\} \text { Index. } \\
& \text { I } 853 \text { Halom, White, Directory. }
\end{aligned}
$$

O.E. et healum, "at the valleys." The place is situated at the foot of a lofty range of hills. The ending represents the dat. pl. of O.E. healh. All the early forms contain but one $l$, so that the first syllable was open, which explains the quantity of the vowel. 
Isaac Taylor (Engl. Village Names) explains this name as meaning "at the slopes." The exact sense of O.E. healh is very uncertain; the transition from "valley" to "slope" is easy and natural.

Halloughton [hōtn] (Hortn, Hope).

$$
\begin{aligned}
& \text { I29I }\} \text { Halton }\left\{\begin{array}{l}
\text { Tax. Eccl. } \\
\text { F.A. } \\
\text { I428 }
\end{array}\right. \text { I637 Haulton, Map in Camden. }
\end{aligned}
$$

O.E. healh tün, "the farmstead in the healh or valley." We have to deal with two types, of which the first and most primitive is, curiously enough, represented by the modern spelling only. The latter may rest on local tradition strengthened by records not generally available.

The O.E. prototype has developed in two directions. Type I : A glide arose between $l$ and $h$ similar to that in borough from O.E. burh, buruh and spelt in the same fashion. This accounts for the modern official form. Type II : The $h$ was dropped between the $l$ and the $t$; afterwards an $u$-glide developed before the $l$ which then disappeared. The old spellings and the modern pronunciation illustrate the latter line of change.

HARBY.

$$
\begin{aligned}
& \text { I086 }\left\{\begin{array}{l}
\text { Herdebi } \\
\text { Herdrebi }
\end{array}\right\} \text { D.B. } \\
& \text { I29I Herdebi, Tax. Eccles. } \\
& \text { I } 302 \text { Hordeby, F.A. }
\end{aligned}
$$

The additional $r$ in the second D.B. form is due to a blunder. The name stands for O.E. heorda $b \bar{y}(r)$, "the herdsmen's dwelling," from Mercian heorde, "a herd," and Scand. $b \bar{y} r$, "dwelling." The $o$ in the F.A. spelling is a M.E. representative of older eo. The phonetic development of the name is regular : $d$ is lost between two consonants, er becomes ar (Phonology, § 8).

HARWELl or HAREWELl.

I086 Herewelle, D.B.

I 227-77 Herewell, Non. Inq. 
The etymology of this name is uncertain. Various suggestions of a more or less convincing nature can be offered.

(I) The first element looks like O.E. here, "army, band of thieves," in a special sense "the Danish army." It is not unlikely that this spring (well) took its name from the fact that an army of the Norsemen once camped near it on one of the numerous plundering expeditions mentioned in the Anglo-Saxon Chronicle. If this suggestion is accepted, the meaning of the pl. n. would be at pēere here welle, "at the spring or brook of the Danish army." Similar names are found on the continent. Förstemann (II) records O.H.G. Heribrunnum, Heriburnon.

(2) The adjective heoru-weallende, "fiercely boiling," occurs in O.E. poetry and might very well be applied to a spring or brook. A similar compound heoru-well, "the fiercely boiling spring," is a possible ancestor of the modern name. There is nothing extraordinary in the suggestion of a fierce and raging well or stream of water. Several brooks called Wuodaha in O.H.G., modern Wutach', meaning "raging brook," are found in Germany.

The phonetic development is regular. The alternative spelling represents an attempt at popular etymology.

HARWORTH [hærəp] (Harroth, Hope).

I086 Hareworde, D.B.

I 278 Harewurh, H.R.

I 346 Hareworth, F.A.

From O.E. Hearanweorb, "the homestead of Heara." The pers. $n$. involved is recorded once in the Onomasticon. The final $h$ in the H.R. spelling is an unsuccessful attempt by the Norman scribe to render the unfamiliar spirant $b$.

HATFiELD (under Norton).

1278 Haytfeld, H.R.

I29 I Hattefeld, Cal. Rot. Chart.

${ }^{1}$ See Schröder, p. 8. I do not agree with the interpretation of this name as "producing rage, or madness." What the idea underlying the creation of this name was, may be gathered from the following quotation from Grabbe's " Hermannschlacht" (Zweiter Tag): "Helft doch unserer armen Retlage. Sie wollen den Bach überschreiten, und so klein er ist, wehrt er sich und schwillt ganz ärgerlich auf!" 
I332 $\left\{\begin{array}{l}\text { Hethfeld } \\ \text { Hadfeld } \\ \text { Hatfeld }\end{array}\right\}$ For. Rec. ed. Stevenson, p. 399.

I57 I Hatfield, Index.

O.E. hä $b$ feld, "the heathy field, or plain." The H.R. spelling distinctly points to influence of Scand. heitr, "heath." The $a$ of the modern form is the result of early shortening of O.E. $\bar{e}$ before the combination $t f$. The stopping of the open $b$ before $f$ is a curious feature. Mr Duignan gives the same explanation for the Staffs. Hatfield. The pl. n. spelt Hadfeld in Bede is modern Hatfield.

Hatfield is now the name of two farms in-Norton, but originally it was applied to the district in the north of the county marked by sand and fen. It is, therefore, clear that the O.E. hāe feld was first employed to designate the whole plain, and that the village which sprang up in it became known as in $h \bar{e} p$ felde, "in the heath field."

\section{HAUGHTON.}

\section{Type I.}

I086 Hoctun, D.B.

$1203\left\{\begin{array}{l}\text { Hoctune } \\ \text { Octon }\end{array}\right\}$ Index.

1278 Hockton, H.R.

Type II.

I 375 Hoghton, Index.

"The tìn or farm of Hōc." Although there is no sign of a genitive termination, I take the first element to be the Scandinavian man's name Hauk(r), anglicised to Hōc. The phonetic changes resulting in the modern form are in accordance with general rules. O.E. Hōk(r)tiun (perhaps containing the Scand. genitival $r$, see Björkman, p. 184) > Hoktun with shortening of $\bar{o}$ before $k t$ (Phonology, $\S \mathrm{I})$; this is Type I. Before $t$, $k$ was opened, developing into $h$ (Phonology, $\S 20$ ), a change which led to Type II and eventually to the modern form. On $a u$ for M.E. ou see Phonology, $§ 9$. 
HAWKSWORTH.

$$
\text { Type } I \text {. }
$$

I 89 Houkeswarda, P.R.

$$
\text { Typé II. }
$$

I086 Hochesuorde, D.B.

$1302\left\{\begin{array}{l}\text { Hokeworth } \\ \text { Hokesworth }\end{array}\right\}$ F.A.

"The homestead of Hauk(r) or Hōc." Type I and the present-day spelling exhibit the Scandinavian pers. $n$. in its more primitive shape. The diphthong ou was anglicised to $\bar{o}$ which is found in Type II. On modern au for M.E. ou see Phonology, §9.

HAWTON.

$$
\begin{aligned}
& \text { Type } I \text {. } \\
& \text { I086 Holtone, D.B. } \\
& \text { Type II. } \\
& 1086 \text { Houtune, D.B. }
\end{aligned}
$$

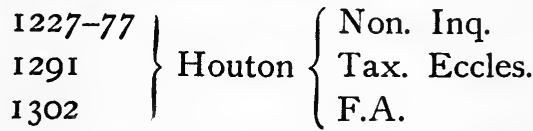

$$
\begin{aligned}
& \text { Type III. }
\end{aligned}
$$

1270 Hautone, Index.

O.E. holt-tün, "the dwelling in the wood," from O.E. holt, "holt, wood." The name is identical in meaning with the numerous Woottons <wudu tün. In Type I, the original $l$ is preserved; between it and the preceding $o$, an $u$-glide arose. The $l$ then disappeared (see Phonology, $§ 9$ ). In M.E., the ou of Type II soon developed into au, giving rise to Type III which is represented by the modern spelling (see Phonology, §).

Hayton.

$$
\begin{aligned}
& \left.\begin{array}{l}
\text { I } 54-89 \\
\text { I } 278 \\
\text { I } 327-77
\end{array}\right\} \text { Haythona, Index. } \\
& \text { I } 428
\end{aligned} \text { Heyton, }\left\{\begin{array}{l}
\text { H.R. } \\
\text { Non. Inq. }
\end{array}\right.
$$

Probably heid tün, "the farm in the heath." The first

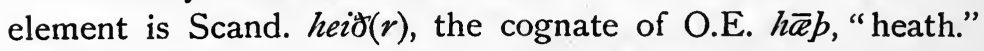


HAYWOOD OAKS.

Haywood stands for M.E. heze wood, "a fenced in or enclosed wood"; O.E. heje, a derivative of O.E. haga, means "a hedge, fence."

\section{HAZELFORD FERRY [hæzlfəd].}

$$
\text { I278 Hesilford, H.R. }
$$

The meaning is obvious. In northern M.E., the name of the plant involved was hesel, from Scand. hesli, "a collection of hazels." See Rygh, N. Gaardnavne, p. 57. The latter form is found in the spelling of 1278 . This probably is the correct form, whereas the modern name has been influenced by the Standard English variant hazel. In White's Directory (I853), the name is spelt "Heaselford," $e a$ representing M.E. $\bar{\varepsilon}$, from older $e$ in open syllable.

HEADON [hīdn].

$$
\begin{aligned}
& \text { 1086 Hedune, D.B. } \\
& \text { I } 302 \text { Hedun, F.A. } \\
& \text { I } 362 \text { Hedon, Index. }
\end{aligned}
$$

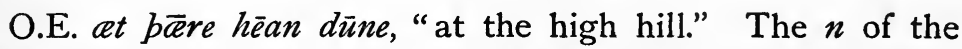
weak dative must have been lost at a very early period (Sweet, N.E. Gr. $\$ 1030-33)$. O.E. diun, "hill," is the ancestor of modern down, "open high land."

\section{Heck Dyke (brook).}

The second part is O.E. dic, "ditch," see Bycardyke. I cannot explain the first element.

Hedgrove (in Southwell).

No early forms. It is possible that the name stands for hedge grove [hed 3 grouv], with loss of the middle consonant [ 3 ; ; cf. Phonology, § I 2.

Hempshill [hemsal].

$$
\text { Type } I \text {. }
$$

I086 Hamessel, D.B.

$\left.\begin{array}{ll}\text { I275 } & \text { Hamdisel } \\ \text { I278 } & \text { Homeshull }\end{array}\right\}$ H.R. 


\section{Type II.}

(a) c. 1200 Hemdeshill, Woll. MSS.

I216-1307 Hemdeshil, Testa de N.

I 275 Hemdeshyll, H.R.

(b) I209-10 Hindeshull, P.R.

(c) 1702 Hempsall, Index.

The first element has the appearance of a man's name in the genitive case. The second seems to stand for either O.E. (W. Sax.) setl, (Northern) seðel, séld, "seat, abode, residence," or O.E. hyll, "hill." The spellings under Type II $b$ and $c$ are influenced by analogy of hind, "female deer," and of hemp, the plant, respectively.

HESLEY.

I 2 I7 Heselay, Index.

"The hazel lea, or open field." The first element is Scandinavian hesli, "hazel grove," see Hazelford.

HICKLING [iklip].

$$
\begin{aligned}
& \text { I086 }\left\{\begin{array}{l}
\text { Hechelinge } \\
\text { Hegelinge }
\end{array}\right\} \text { D.B. } \\
& \text { I } 284 \text { Hickelinge, F.A. } \\
& \text { I } 29 \text { I Hicling, Tax. Eccles. }
\end{aligned}
$$

An O.E. patronymic : at (H)iclingum, "at the dwelling-place of the family of Hicel." The Iclingas were a noble family to whom St Guthlac belonged. It is, however, by no means certain that Hickling was a settlement of that particular clan. The descendants of any man called Hicel would be styled Hicelingas.

The $e$ in the D.B. forms stands for O.E. $i$ according to a frequent practice of Anglo-Norman scribes (see Stolze, $\S 9$ ).

HOCKERTON.

$$
\begin{aligned}
& \text { I086 }\left\{\begin{array}{l}
\text { Hocretune } \\
\text { Ocreton }
\end{array}\right\} \text { D.B. } \\
& \text { c. I } 200 \text { Hocretona, Index. } \\
& \text { I } 302 \text { Hokyrton, F.A. }
\end{aligned}
$$

"The tiun or homestead of Hōc." This pers. n. is Scandinavian in origin (see Hawksworth). The $r$ represents the Norse genitival ending (see Björkman, p. I84). 
HoDSOCK.

\section{Type $I$.}

Io86 Odesach, D.B.

I 302 Hodesak

$\left.\begin{array}{ll}\text { I316 } & \text { Hoddisack } \\ \text { 1346 } & \text { Hodelake (sic!) }\end{array}\right\}$ F.A.

\section{Type II.}

I 278 Hoddeshock, Inq. P.M. II.

The second element of this pl. n. is O.E. $\bar{a} c$, "oak"; the first is a pers. n., probably Scandinavian Oddi. The $h$ may be due to influence of the O.E. pers. ns. Hod, Hoda, Hodo (Onomasticon); it is more likely, however, that it is a mere inorganic addition, initial $h$ being a very unstable element in this dialect (see Phonology, §19).

The vowel of O.E. $\bar{a} c$ was shortened at two different periods in the unstressed syllable: (I) In O.E. times; result $a$, Type I. (2) In M.E.; result $o(<\bar{o})$, Type II and modern spelling. The second $h$ of Type II is due to confusion with $h \bar{c} c$, "a heel, promontory."

N.B. It may be mentioned here that Hodesac is found in an O.E. charter (Cart. Sax. 1282) among Worcestershire field names and boundaries.

HOLBECK or HOWBECK or HOLBEACH.

I 329 Holbeck, Index.

"The brook in the hollow." From O.E. holh, "hollow," and Scand. bekk(r), "a brook." The termination -beach goes back to O.E. $b a c$, with palatalised $c$, the native equivalent of $b e k k r$. This word is found in pl. ns. ending in batch, bach, beach, and is discussed at length by Professor Skeat in his Pl. Ns. of Cambs. (pp. 44 sq.).

It is impossible to say whether the O.E. or Scand. form was the original one.

The vocalisation of $l$ is treated elsewhere (Phonology, $\S 9$ ).

Holme.

$$
\begin{aligned}
& \text { c. } 1200 \text { Olm, Index. } \\
& \text { 1316 Holme, F.A. }
\end{aligned}
$$

This common English pl. n. is derived from Scand. holm(r). Its meaning is "island in river, land rising from water." There 
is an open pasture on the Trent bank at Normanton called "the Holme." The above pl. n. seems to have had the same meaning originally.

Holme PiERREPONT.

$$
\begin{aligned}
& \text { I086 Holmo, D.B. } \\
& \text { I } 302 \text { Holm, F.A. }
\end{aligned}
$$

For the meaning of M.E. holm see the preceding name. The final $o$ in D.B. is remarkable; I do not pretend to be able to explain it.

The distinctive addition is due to the fact, that the Pierrepont family of Norman descent, now the Earls Manvers, owned and still own the manor: "Annora de Perpunt tenet manerium de Holm," F.A. I 302.

HORSEPOOL (now the name of a decayed farm near Thurgarton).

$$
\left.\begin{array}{ll}
\text { I086 } & \text { Horspol, D.B. } \\
\text { I } 302 & \text { Horppol (sic!) } \\
\text { I } 3 \text { I } 6 & \text { Horspol }
\end{array}\right\} \text { F.A. }
$$

The name explains itself.

Houghton, see Haughton.

HOVERINGHAM.

$$
\text { Type } I \text {. }
$$

(a) 1278 Offringham, H.R.

. I428 Overyngham, F.A.

I 535-43 Oringgam, Leland.

(b) 1086 Horingeham, D.B.

I 278 Hofrungham, H.R.

I 316 Horingham, F.A.

\section{Type II.}

$$
\left.\begin{array}{ll}
\text { I } 346 & \text { Heveringham } \\
\text { I428 } & \text { Heveryngham }
\end{array}\right\} \text { F.A. }
$$

From O.E. Eoforinga häm, "the home or village of the family of Eofor." Type II shows the regular descendant of O.E. $e o$, which is $e$. The presence of $o$ in Type I is probably the result of a peculiar development of O.E. eo before a labial $(v)$ in 
the dialect. The Scand. man's name Iofr, the equivalent of Eofor-which, by the way, means "boar"-may have influenced the first element, just as it did in the pl.n. York (see Place Names of the W. Riding, p. i).

The addition of an inorganic initial $h$ (Type I $b$, Type II) cannot surprise us (see Phonology, § I9).

The same patronymic name occurs on the continent. Ebringen (Breisgau) goes back to O.H.G. Eburingen, and Everghem, near Ghent, is derived from O. Low Germ. Everingehèm (Förstemann, I and II).

HUCKNALL TORKARD.

I086 $\left\{\begin{array}{l}\text { Hochenale } \\ \text { Hochehale }\end{array}\right\}$ D.B.

I 90 Hukenhall, Woll. MSS.

I 216-1307 Hukenhall, Testa de N.

I 284 Hukenall

$\left.\begin{array}{ll}\text { I } 302 & \text { Huckenale Torkard } \\ \text { I } 3 \text { I6 } & \text { Hokenall }\end{array}\right\}$ F.A.

1327-77 Hukenhale, Inq. P.M. II.

O.E. at Huc(c)an heale, "at or in the valley of Hucca." This pers. $\mathrm{n}$. is recorded in the Onomasticon as Huc and Hucco. It seems to be a short or "pet" form of a full name beginning with Hyge-.

The distinctive addition owes its origin to the fact that the manor was once held by the Norman family of Torkard: "Johannes Torkard tenet in Hukenall," F.A. 1284.

HuCKNALL under HuthwaIte or DiRTy HuCKNall [dati(h)aknə].

c. I 500 Durty Hucknall, Inq. P.M. c. I 500.

I6I I Hucknoll Huthwaite, Index.

I 704 Dirty Hucknall. Quoted by Horner Groves, Hist. of Mansfield, from parish register (p. I 70).

See preceding and following names. The flattering addition of dirty (M.E. dritig, from Scandinavian, see Björkman, Scand. Loan Words) is probably due to the former condition of the 
roads and the surrounding country. I am told that whereas Hucknall-T. stands on limestone, which absorbs water quickly, this village is situated chiefly on clay.

Huthwarte [hapweit], now the official name of the place above.

Probably a late settlement, as is shown by the Scand. origin of the second element, bveit, " piece of land, an outlying cottage with its paddock" (Vigf.). The first element may be the pers. $n$. taken from the neighbouring Hucknall : Hucbwait > Huthwaite by assimilation of $k b$ to $b(b)$.

IDLE (river).

627 Idla, Beda, Hist. Eccles.

1302 Yddil, Index.

The second element may be O.E. è $a$, èze, "water, stream," which was lost entirely as in Greet, Blyth (q.v.). If that is so, I would suggest that the first element was O.E. idel. The recorded meanings of this adjective-"empty, desolate, useless" - do not seem to be applicable to a river. It is, however, believed by some scholars that the original sense was "shining, brilliant," it being related to Greek ai $\theta \omega$ (see Kluge's and Hirt's Etym. Dictionaries, s.v. eitel). If that is so, the sense of O.E. sēo idele èa would be "the bright, clear river."

IDLETON, see EATON.

KeLHAM.

$$
\begin{aligned}
& \text { I086 Calun, D.B. } \\
& \left.\begin{array}{l}
\text { I } 189 \\
\text { I } 225
\end{array}\right\} \text { Kelum }\left\{\begin{array}{l}
\text { P.R. } \\
\text { Bor. Rec. }
\end{array}\right. \\
& \text { 1227-77 Kelm, Non. Inq. }
\end{aligned}
$$

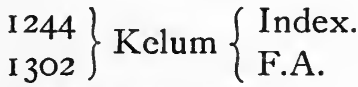

$$
\begin{aligned}
& \text { I316 Kelme, F.A. } \\
& \text { I350 Kelom } \\
& \left.\begin{array}{rl}
\text { I } 453 & \text { Kelum } \\
\text { I } 578 & \text { Kellam }
\end{array}\right\} \text { Index. }
\end{aligned}
$$

From O.E. at celdum, "at the water-courses." This name corresponds to the Latin aquis. The initial $k$-sound proves that the noun involved is derived from the Scandinavian language, 
O.N. kelda, "well, spring, brook flowing from a spring." The modern spelling in -ham is due to false analogy with pl. ns. ending in O.E. hàm, "home."

The same meaning attaches to the neighbouring Averham (q.v.).

KERSALL.

Type $I$.

I086 Cherveshale, D.B.

Type II.

$\left.\begin{array}{ll}\text { I } 302 & \text { Kyrneshall } \\ \text { I } 3 \text { I6 } & \text { Kyrnissale }\end{array}\right\}$ F.A.

The second element is O.E. healh (dative heale), "a valley." The pers. $n$. contained in the first element cannot be determined with accuracy. The $v$ in D.B. may be a misreading for $u$, which in turn might stand for $n$; if that be so, Type I would be the same as Type II. The latter may contain the O.E. male name Crin or Crina, recorded in the Onomasticon. Metathesis of $r$ is frequently met with in this dialect (Phonology, $§ 15$ ). er in the modern form is a mere spelling variant for $i r$, both representing the same sound in present-day English.

KEYwORTH [locally: kjuəp; otherwise: kīwn̄p].

Type $I$.

I086 Caworde, D.B.

Type II.

I200 Kyeword, Cal. Rot. Chart.

I216-1307 Kewurch, Testa de N.

c. 1294 Keword, Woll. MSS.

$1302\left\{\begin{array}{l}\text { Kewrth } \\ \text { Kewrht } \\ \text { Keworth }\end{array}\right\}$ F.A.

I637 Kyworth, Map in Camden.

The D.B. scribe seems to have mistaken the first element for the pers. n. Cawa, Ceawa. I take this name to stand for O.E. $c \bar{y} w o r b$, "the cow enclosure, or farm." $c \bar{y}$ represents either the genitive singular or the nominative plural of O.E. $c \bar{u}$, "cow." The spellings show that by the year 1200 the accent has been 
shifted from the $\bar{y}$ to the $u$ developed out of the $w$. After this change, the $\bar{y}(\bar{i})$ degenerated into a mere palatal glide [j]. With these sound-changes may be compared the analogous history of modern English ewe< O.E. êrou. The combination ey in the modern form is a mere spelling device to express this glide, which is represented by $e$ or $y$ in earlier records. The polite pronunciation is based entirely on the written form, whereas locally the etymologically correct form survives.

KiLvington.

$$
\begin{aligned}
& \text { I086 }\left\{\begin{array}{l}
\text { Chilvintun } \\
\text { Chelvinctone }
\end{array}\right\} \text { D.B. } \\
& \text { I } 29 \text { I Kilington, Tax. Eccl. } \\
& \left.\begin{array}{ll}
\text { I } 302 & \text { Kylvington } \\
\text { I428 } & \text { Kylyngton }
\end{array}\right\} \text { F.A. } \\
& \text { I637 Skillington, Map in Camden }
\end{aligned}
$$

From O.E. Cylfinga tün, "the tün or homestead of Cylfa's descendants." The $c$ in the second D.B. spelling clearly demonstrates that a patronymic name forms the first element. Cylfa is once recorded in the Onomasticon. From a number of early forms it would appear that the $v$ was dropped at an early period in pronunciation but retained in writing. From this fact one would expect the local pronunciation to be [killintn, killintn]. The initial $S$ of Camden's map must be due to a blunder.

KimbeRLEY.

$$
\text { I086 }\left\{\begin{array}{l}
\text { Chinemareleie } \\
\text { Chinemarelie }
\end{array}\right\} \text { D.B. }
$$

c. I 200 Kinemarle, Woll. MSS.

1227-77 Kymm'ley, Non. Inq.

I 29I Kynmarley, Tax. Eccles.

$\left.\begin{array}{ll}1316 & \text { Kynmarleye } \\ 1428 & \text { Kymerley }\end{array}\right\}$ F.A.

I 589 Kymmerley alias Kymberley, Index.

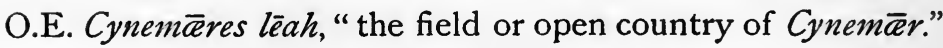
It is remarkable that the genitival $s$ is absent from all the early spellings. The phonetic history can be easily traced through the centuries, and affords instructive examples of the various processes of shortening and assimilation to which pl. ns. are liable. 
KINGSTON-UPON-SOAR.

\section{Type $I$.}

I086 Chinestan, D.B.

$\left.\begin{array}{l}\text { 1216-72 } \\ \text { 1256 }\end{array}\right\}$ Kyn(n)estan $\left\{\begin{array}{l}\text { Index. } \\ \text { Inq. P.M. I. } \\ \text { I } 291 \text { Kynstan, Tax. Eccles. } \\ \text { 1302 Kyneston } \\ \text { I346 Kynston }\end{array}\right\}$ F.A.
1637 Kynston, Map in Camden.

Type II.

1592 Kyngston, Index.

O.E. cyne-stān, "royal stone." The first element is the O.E. adj. cyne-, "royal," which occurs in compounds. I am unable to say what the "royal stone" involved was, or why it was so named. It must be remembered that in O.E. times, the title of "king" was applied not only to the rulers of large dominions but also to the petty chiefs of minor clans; hence its frequent use as a modern surname. In fact, the word originally had the wide meaning of "nobleman, one of a noble family" (see Kluge, Etymol. Wörterbuch, s.v. König).

The change from $a$ to $o$ in the ending is not due to phonetic development but to erroneous etymology, the $s$ being considered the genitival ending of some pers. $n$. preceding the more familiar ton, O.E. tīn. Thoroton the historian must have been labouring under the same delusion when he explains the name as, "So called, probably, from an Owner, as most Towns of that termina. tion, in this County, generally."

Popular etymology is also responsible for the change from Type I to Type II.

KinOULTON.

I086 Chineltune, D.B.

I 52 Cheneldestoa, Index.

$\left.\begin{array}{ll}\text { I284 } & \text { Kynalton } \\ \text { I } 302 & \text { Kynolton }\end{array}\right\}$ F.A.

O.E. Cynervealdes tīn, "the farmstead of Cyneweald." This is an example of the complete loss of the genitival $s$ which is 
preserved only in the most archaic form. The phonetic development is regular (see Phonology, $\$$ I 8 ; 9).

The final $a$ for $n$ of the Index is, of course, a scribal mistake.

KIRKBY-IN-ASHFIELD.

Io86 Chirchebi, D.B.

I $240\left\{\begin{array}{l}\text { Kirkeby } \\ \text { Kirkby } \\ \text { Kyrkeby }\end{array}\right\}$ Bor. Rec.

1302 Kirkeby

I316 Kirkeby super Asshefeld $\}$ F.A.

A Norse name, of which many instances are found both in England and in Scandinavia: "the church village," from O.N. kirkja and $b \bar{y}(r)$. It may be remarked here that the combination ch in D.B. does not express the sound of $c h$ in modern English church, but represents $k$ before palatal vowels (Stolze, $\S 40, \mathrm{I}, 2$ ).

The distinctive addition refers to the district in which the village is situated: O.E. esc feld, "the field or plain of the ashtree(s)."

KIRKLINGTON.

\section{Type $I$.}

I086 Cherlington, D.B.

I 29I Kirtelyngton, Tax. Eccles.

1302 Kyrtelington ?

I428 Kyrtelynton $\}$ F.A

c. I 500 Kyrtelyngton, Inq. P.M. c. I500.

\section{Type II.}

I 346 Kyrkelington, F.A.
1437
c. 1500
Kirklington $\{$ Index.
Inq. P.M. c. I 500.

"The dwelling-place of the family of Cyrtel," O.E. Cyrtelinga tün. The pers. n. involved is discussed under Costock. It is formed from a name Curt by addition of the diminutive ending $i l$ which caused mutation of the preceding vowel.

The change from $t l$ to $k l$ may be due to purely phonetic forces. However, the analogy of the independent word kirk may have had some influence in rendering Type II the predominant form. 
The Yorks. pl. n. Kertlington is spelt Kirtlington and Kirklington in Cal. Inq. P.M. temp. Edw. I. It seems to contain the same patronymic.

KIRTON.

\section{Type I.}

1086 Circeton, D.B.

\section{Type II.}

I086 Chircheton, D.B.

$\left.\begin{array}{l}\text { c. } 1200 \\ \text { 1316 }\end{array}\right\}$ Kyrketon $\left\{\begin{array}{l}\text { Index. } \\ \text { F.A. }\end{array}\right.$

c. I $500\left\{\begin{array}{l}\text { Kyrkton } \\ \text { Kyrton }\end{array}\right\}$ Inq. P.M. c. I 500 .

"The church town, or village." Type I is entirely English in character, whereas Type II substitutes Scand. kirkja for the cognate Anglo-Saxon iirice. In D.B. $c$ before palatal vowels is used to render the sound of modern English $c h$ [ $\mathrm{t}$ ], whereas $c h$ in the same position stands for $k$ (see Stolze, $\S 40$, I, and cp. Kirkby).

KNAPTHORPE (under Caunton).

$$
\begin{aligned}
& \text { I086 Chenapetorp, D.B. } \\
& \text { I278 Konaptorp, H.R. } \\
& \text { I302 Knapthorp, F.A. }
\end{aligned}
$$

"The hamlet of Knapp, or Knappi." This pers. n. is not given by Dr Björkman. However, the second element of the pl. n. porp being of Scand. origin, it is safe to conclude that the first too comes from the same source. Rygh (G. Pers. Nav. p. I6I) gives examples of the occurrence of Knappr, Knappi in O.N. pl. ns.

It might also be suggested that this name contained the O.E. substantive $\operatorname{cnap}(p)$, "top, mountain top," M.E. knape $e^{1}$. I am, however, strongly in favour of the first interpretation.

The vowels $e, o$ between the $k$ and $n$ were put in by the Normans who found it impossible to pronounce the two consonants in this combination.

1 Leland says of Belvoir Castle that it "standith on the very Knape of an highe Hille." 
KneESAll [nīsə] (Kneaser, Hope).

I086 Cheneshale, D.B.

I 89 Cneeshala, P.R.

I230 Keneshale, Index.

1278 Kneshale, H.R.

$\left.\begin{array}{ll}\text { I302 } & \text { Kneshall } \\ \text { I3 } 16 & \text { Kneshale }\end{array}\right\}$ F.A.

The second element is O.E. healh, "valley." I cannot explain the first, although I suspect it to stand for O.E. Cnihtes, or cnihtes, the genitive of either the pers. n. Cniht, or the identical noun meaning "boy, servant, attendant, retainer." If it could be proved that the genuine development of O.E. ih in this dialect

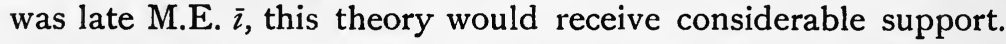
The Dial. Grammar is too untrustworthy a guide to be relied upon in such cases. I have been informed that old people in the district say [nīt] for night, but have never been able to establish this fact beyond doubt. The voiceless $s$ in the pronunciation recorded above would seem to point back to early M.E. ts (cp. Cossal).

The vowel-glide between the $k$ and the $n$ in Norman documents is explained elsewhere (see Knapthorpe; and the following name).

KNEETON or KNEVETON.

Type $I$.

I695 Knighton, Map in Camden.

Type II.

I086 Chenivetone, D.B.

$\left.\begin{array}{l}\text { c. I I90 Chnivetun } \\ \text { c. I } 2 \text { I0 Knitona }\end{array}\right\}$ Woll. MSS.

I284 Knyveton, F.A.

I29I Kenyveton, Tax. Eccles.

O.E. cnihta tün, "the farmstead, or settlement of the servants." The exact sense in which the O.E. cniht is used here is obscure. Originally it meant "servant," as its German cognate Knecht still does. In course of time, the O.E. word assumed a different meaning, being applied to the retainers of a king or 
powerful lord whom they served as warriors, or men-at-arms. They belonged to a new nobility, ranking above the lower orders from which they had sprung. The word is, however, most certainly not used here in its still further specialised M.E. sense, that of "chevalier." Isaac Taylor (Engl. Village Names, § 3) counts fifteen villages called Knighton in England.

On modern $e e[\bar{i}]$ for O.E. ih see preceding name.

The $v$ of Type II remains to be explained. I take it to represent the faint palatal open consonant of the early M.E. Knighton, as it appeared to the Normans who were unfamiliar with that sound (see Zachrisson, pp. I I9 sqq.).

Considering that the mediæval documents were often written by foreigners, and were moreover copied one from another, it is not surprising that so late an authority as Camden should furnish us with the most useful spelling.

LAMBLEY.

I086 Lambeleia, D.B.

I316 Lameleye, F.A.

"Lamb lea, or field." O.E. lamb lēah.

LAMCOTE.

Type $I$.

1086 Lanbecotes, D.B.

Type $I 1$.

I086 Lanbecote, D.B.

I3 6 Lambecote, F.A.

O.E. lamb cotas, "the lamb cotes" (Type I), at lamb cotum, "at the lamb cotes" (Type II); $m b$ is often spelt $n b$ in D.B. ; see early forms of Clumber, and Cromwell.

LANEHAM.

$$
\left.\begin{array}{l}
\text { I086 Lanun, D.B. } \\
\text { I } 278 \\
\text { I } 316
\end{array}\right\} \text { Lanum }\left\{\begin{array}{l}
\text { H.R. } \\
\text { F.A. }
\end{array}\right.
$$

O.E. et lanum, " at the lanes," dat. pl. of lane, "lane, street, narrow way between hedges or banks." The modern spelling is another instance of the O.E. dat. pl. ending -um being mistaken for hām, " home." 
LANGAR.

$$
\begin{aligned}
& \left.\begin{array}{l}
\text { I086 } \\
\text { c. } 1190
\end{array}\right\} \text { Langare }\left\{\begin{array}{l}
\text { D.B. } \\
\text { Woll. MSS. } \\
\text { I } 241 \text { Langar, Cal. Rot. Chart. } \\
\text { I } 302 \\
\text { I637 }
\end{array}\right\} \text { Langer }\left\{\begin{array}{l}
\text { F.A. } \\
\text { Map in Camden. }
\end{array}\right.
\end{aligned}
$$

O.E. se langagär, "the long triangular strip of land." The second element gär corresponds to the O.H.G. gêro, modern German Gehre, which is encountered in numerous field names throughout Northern Germany. It is discussed at length by Dr Jellinghaus (p. 283). The modern Engl. equivalent is gore, "a triangular piece of land."

LANGFORD.

$$
\begin{aligned}
& \text { I086 Landeforde, D.B. } \\
& \left.\begin{array}{l}
\text { I } 302 \\
\text { I } 346 \\
\text { I } 428
\end{array}\right\} \text { Landeford, F.A. } \\
& \left.\begin{array}{l}
\text { I470 Lanford } \\
\text { I472 Lanforth } \\
\text { I } 555 \text { Landford }
\end{array}\right\} \text { Index. }
\end{aligned}
$$

"The ford leading to the plough-lands." The change of $n(<n d)$ to $n g[\mathrm{~g}]$ is very remarkable. It did not take place until a comparatively late period. The dialect word lang, "long," may have had some influence.

O.E. land has the special sense of "cultivated land, estate." There was a pl. n. called Lanfurt in Friesland (Förstemann, II) which contained the same element, land, meaning "ager, rus."

The spelling in -forth (1472) betrays influence of Scand. fioror.

\section{LANGWITH.}

I 29 I Langwaith, Cal. Rot. Chart.

I 57 I Langwith, Index.

It is impossible to say whether the second element stands for Scand. $v a \delta$, "a wading place, ford," or for viðr, "tree, wood, forest." See other examples of this confusion under $\mathrm{Var}$ and Viðr, pp. 394 and 395 of Lancs. Pl. Ns. However, I feel 
inclined to explain the name as meaning "long ford." For such a name there are several analogies: Langwith Wood, Yorks., appears as "Haya (an enclosed wood) de Langwath" in 1286 (Index), and there is a Longford in Lancs.

LAXTON.

\section{Type I.}

(a) 1086 Laxintune, D.B.

I 278 Lexington, H.R.

c. I 300 Lexinton, Index.

(b) 1278 Lessinton, H.R.

Type II.

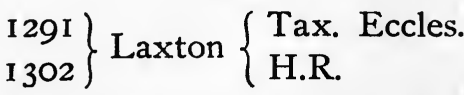

"The tīn or homestead of Leaxa, or the Leaxings." This pers. $n$. is found once in O.E., in the Index to Kemble's Cod. Dipl. as first element of a pl. n. : Leaxan oc, "the oak of Leaxa." The phonetic development can be traced through the early spellings without difficulty. The $s s<k s$ of Type I $b$ distinctly points to Norman influence.

LEAKE (East or Great L., and West or Little L.).

$$
\begin{aligned}
& \text { I086 }\left\{\begin{array}{l}
\text { Lecche } \\
\text { Leche }
\end{array}\right\} \text { D.B. } \\
& \text { I227-77 Leyk, Non. Inq. } \\
& \text { I } 302\left\{\begin{array}{l}
\text { Esterlek } \\
\text { Westerleke }
\end{array}\right\} \text { F.A. } \\
& \text { I637 }\left\{\begin{array}{l}
\text { Esterleak } \\
\text { Westerleak }
\end{array}\right\} \text { Map in Camden. }
\end{aligned}
$$

"At the brook." The name is derived from an O.N. word l $\phi k r$, "a brook, rivulet," which is a cognate of O.E. lacu, "lake, running water," and connected with modern Engl. to leak. The village of East Leake is situated in a hollow of the South Wolds through which a small rivulet flows.

LEEN (river).

c. 1200 Liene, Woll. MSS.

1535-43 Line Ryver, Leland, I, IO3.

I637 Lin, Camden, p. 547.

M. 
Apparently a Celtic river-name. There is a river Len in Kent, and we also find a Leenane in co. Galway, a Leane in co. Kerry, and a Leanane in co. Donegal. See Stevenson, Asser's Life of King Alfred, p. 318, where a similar river-name is discussed.

The name Lenbach is found on Bavariann territory.

LENTON.

$$
\begin{aligned}
& \text { I086 Lentune, D.B. }
\end{aligned}
$$

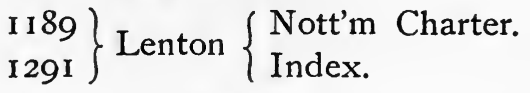

$$
\begin{aligned}
& \text { I637 }\left\{\begin{array}{l}
\text { Linton } \\
\text { Lenton }
\end{array}\right\} \text { Camden, p. } 547 .
\end{aligned}
$$

"The tiun, or settlement on the river Leen." See Leen.

LeVERTON (North and South).

$$
\text { Type } 1 \text {. }
$$

I086 Cledretone, D.B.

$$
\text { Type II. }
$$

(a) 1086 Legretune, D.B.

c. 1200 Legherton, Cal. Rot. Chart.

$$
1278\left\{\begin{array}{l}
\text { Nordleg'ton } \\
\text { Sudleg'ton }
\end{array}\right\} \text { H.R. }
$$

(b) 1 I 89 Leirton, P.R.

1216-1307 Leyrton, Testa de N.

I28I Norhtleyrton, Inq. P.M. I.

\section{Type III.}

\section{73-4 Leuerton, P.R.}

The etymology of this name is very obscure. Type III, which may be the most reliable spelling, looks as if it were derived from an O.E. compound Lêofhere(s) tün. The same personal name seems to be contained in "Liverpool," see P1. Ns. of Lancs.

For a possible explanation of the relations between $d[\gamma], g$, and $v$, in Norman spelling see discussion under Averham. 
LIDE (more correctly Lythe) (Wapentake, now part of the hundred of Thurgarton).

\section{Type I.}

I086 Lide Wap, D.B.

$\left.\begin{array}{l}1302 \\ 1346\end{array}\right\}$ Wapentakium de...Lith, F.A.

Lythe, Thoroton.

Type II.

1278 Lye, H.R.

(Thurgarton a) Lee, Thoroton.

This name seems to be that of a river. Perhaps from O.E. lïpe e $a$, "the gentle stream." lïbe is identical with modern Germ. linde, both meaning " mild, calm, gentle, pleasant." The adjective was occasionally applied to flowing water, as in a M.E. version of the Psalter, quoted in N.E.D., s.v. lithe: "His stremes leften lithe" (et siluerunt fluctus ejus, cvi. 29).

See Blyth, which has the same meaning.

The loss of intervocalic $\delta$ (Type II) is a regular feature.

Limpool (under Harworth).

$$
\text { c. } 1500 \text { Lympole, Inq. P.M. c. } 1500 .
$$

Probably from O.E. at lind pōle, "at the pool of the limetrees."

LinBy.

$$
\begin{aligned}
& \text { I086 Lidebi, D.B. } \\
& \text { I } 316 \text { Lyndebi, F.A. }
\end{aligned}
$$

O.E. lind $b \bar{y}(r)$, "the dwelling near the lime-trees." From O.E. lind, "lime-tree," and Scand. $b \bar{y}(r)$, "a dwelling, village."

The D.B. scribes frequently omit $n$ before other dental consonants (Stolze, $\S 32$ ); this is due to a peculiarity of their Norman-French pronunciation: the $i$ in the above spelling was nasalised, and the consonant $n$ dropped.

LitTLEBOROUGH.

$$
\text { Type } I \text {. }
$$

1535 Litilborowe, Valor Eccles. 


\section{Type II.}

I086 Litelburg, D.B.

I428 Lytilburgh, F.A.

I 535 Litilbrugh, Valor Eccles.

I637 Lyttleburgh, Map in Camden.

"The small fortified place, the small Roman fort." The word O.E. burh is often applied to old fortifications especially of Roman origin. It is constantly used of Rome itself, of London and other walled cities. Littleborough is generally believed to stand on or near the site of the Roman station Agelocum or Segelocum. Cp. Brough.

Type II represents the O.E. nominative $l \bar{y} t l o b u r(u) h$, whereas Type I stands for the dative at bēere lyttan burze, with $u$ for $y$ by analogy of the nom. and accus. cases, Sievers, $\S 284$, anm. 4 .

LOUND.

$$
\begin{aligned}
& \left.\begin{array}{l}
\text { I086 } \\
\text { I } 278
\end{array}\right\} \text { Lund }\left\{\begin{array}{l}
\text { D.B. } \\
\text { H.R. }
\end{array}\right. \\
& \text { I } 302 \text { Lound, F.A. }
\end{aligned}
$$

"The wood, copse." From Scand. lundr, "wood, copse." The lengthening of the $u$ before $n d$ took place in England after the word was introduced into the language. This word enters into the composition of numerous pl. ns. both in Scandinavia and in the Norse districts of Great Britain. It is also found as an independent word in various forms in the English dialects.

The name of the university town of Lund in Southern Sweden is identical in origin.

LOWDHAM [laudm].

I086 Ludeham, D.B.

$\left.\begin{array}{ll}\text { c. I I } 70 \text { Ludam } \\ \text { c. I } 200 \text { Ludham }\end{array}\right\}$ Woll. MSS.

$\left.\begin{array}{l}\text { I } 278 \\ \text { I 29I }\end{array}\right\}$ Ludham $\left\{\begin{array}{l}\text { H.R. } \\ \text { Tax. Eccles. }\end{array}\right.$

I 302 Loudham, F.A.

I637 Lewdham, Map in Camden.

This name cannot be explained with any degree of certainty. The first element may contain the O.E. pers. n. Lüda, which 
seems to be an abbreviated variant of a full name beginning

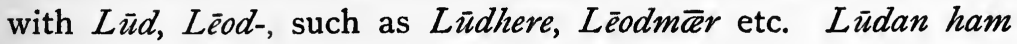
would mean "the homestead of Lüda."

Camden's spelling looks very suspicious. It is most probably a mere blunder.

It might also be suggested that the first element was O.E. hlüd, "loud," which I take to mean "stormy, windy" as well : cp. O.E. $h l y d a$, a name for the month of March, derived from hlüd, "windy," and therefore identical with the ventôse of the French revolutionary calendar. "The stormy-homestead" seems to possess a parallel in the O.H.G. Hludinhusir (Förstemann) which may mean "at the stormy houses," but the first element may equally well be a pers. $\mathrm{n}$. in the genitive case. Cp. Bleasby.

LYNDHURST-ON-THE-FOREST.

I637 Lyndhurst Wood, Map in Camden.

Formerly a wood and part of the forest. The meaning is obvious : "Lime-wood," from O.E. lind, "lime-tree," and hyrst, "a wood, copse, grove."

MANSFIELD.

\section{Type I.}

A.

(a) 1086 Mamesfelde, D.B.

I 63 Mammesfeld, Index.

$\left.\begin{array}{l}\text { I 29I } \\ \text { I } 316\end{array}\right\}$ Mamesfeld $\left\{\begin{array}{l}\text { Tax. Eccles. } \\ \text { F.A. }\end{array}\right.$

(b) I29I Mannesfeld, Tax. Eccles.

B.

(a) II89 Mamefeld, P.R.

(b) I278 Man'efeld, H.R.

Type II.

A.

(a) 1086 Mammesfed, D.B.

(b) 1227-77 Maunnesfeld, Non. Inq.

1278 Maunsfewd, H.R.

1428 Maunsfeld, F.A.

I564 Mawnsfeld, Index.

I657 Maunsfeld, Map in Camden. 
B.

(a) I249 Malmefeud, Inq. P.M. I.

The O.E. prototype of this name was Mammes feld (Types I A and II A), of which a variant Mamman feld (Types I B and II B) existed. These O.E. prototypes of which, as will appear later, the latter was probably the more original one, are most faithfully preserved by the Index spelling of I I $6_{3}$, and the P.R. of I 189 respectively.

The name developed on two different lines among the English and the Norman-French communities. Type I, the native form, survived eventually in the pl. n.; Type II, characterised by the development of a $u$ between $a$ and $n$ (Phonology, $\S \mathrm{II}$ ), and the vocalisation or disappearance of $l$ (cp. Zachrisson, pp. I46 sqq.) $)^{1}$, owes its origin to the peculiarities of Norman-French pronunciation. From the latter type, the name of the river on which Mansfield stands is taken; it is therefore wrong to say that the town derives its name from the river, just the opposite being the case (see Maun).

In both types we perceive the change from medial $m$ to $n$; those forms marked $(a)$ contain the former, those marked $(b)$ the latter consonant. This development may be due to several causes acting simultaneously.

(I) Dissimilation of the sequence $m-m-f$; two consecutive $m$ 's followed by $f$ are difficult to pronounce. This applies especially to Norman-French speakers (see Zachrisson, pp. I 20 sqq.).

(2) The vowel between the $m$ and the $s$ must have disappeared very early, at least in pronunciation if not in spelling. In the combination $m s, s$ would exercise a very strong assimilatory influence upon the preceding nasal.

(3) Popular etymology connected the first element with the word man.

Having explained the development of the name through M.E. and modern times as exemplified by the variety of early spellings, we may now return to the original O.E. form. The meaning of

$1 l$ having become $u$ in Anglo-Norman, al could be written for au as in Malmefeud (Type II B, a). 
Mammes feld is obvious: "the plain of Mamma." This name applied to the whole district, the town, or rather the original settlement being called "on Mammes felde." The final $e$ of the D.B. form (Type I A, a) may be regarded as the last and only trace of the O.E. dative ending. As has already been said Mamman feld was probably more original than the es type. The pers. n. Mamma should follow the weak declension, and must have done so originally; however, as was shown in the case of Annesley (q.v.), the ending an was replaced by the strong es at a very early date in the Midland dialects.

The pers. n. involved is not recorded in O.E. sources. It may, however, be safely inferred to have existed, because it occurs among those West Germanic tribes which remained on the continent. We find O.H.G. Mamo, Mammo as the names of persons, and Mammindorf, modern Mammendorf, Bavaria, as the name of a place (Förstemann, I).

Who the personage was, that gave his name to the plain and town, it is impossible to say. It even is not unlikely that he never existed except in the imagination of the early settlers. The locality may have had a British name, which contained the element $M a m$-, of doubtful meaning and derivation, which is also found in the early forms of Manchester. This Mam-, whose significance the Anglo-Saxons did not know, would promptly be interpreted and used as the pers. n. with which they were already acquainted. They did this the more readily, as the majority of Teutonic pl. ns. were formed on the principle of pers. n. plus designation of locality (see Bradley, Engl. Histor. Review, Oct. I9I I, p. 823). Similar cases of distortion and misinterpretation of British pl. ns. are cited by Isaac Taylor (Words and Places, ch. XII).

Apart from the erroneous, but natural derivation of this name from that of the river, another different and highly ingenious explanation has been offered, namely, that it was bestowed upon the locality by the Counts of Mansfeld in Saxony who came here to attend at the tournament of King Arthur. It may seem a pity to many that the hard facts should destroy so romantic a fiction. 
MANTON.

I086 Mennetune, D.B.

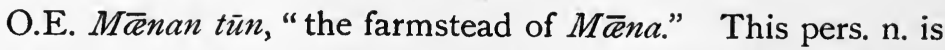
recorded in the Onomasticon. The long vowel was shortened before the combination $n t$ at different periods, which accounts for the variation in vowel of the only two recorded spellings given above.

MAPELBECK.

\section{Type $I$.}

1086 Mapelbec, D.B.

c. I300 Mapilbec, Index.

$\left.\begin{array}{ll}\text { I302 } & \text { Mapelbek } \\ \text { I3 } 6 & \text { Mapulbek }\end{array}\right\}$ F.A.

c. $I 500\left\{\begin{array}{l}\text { Mapulbeke } \\ \text { Malebeke }\end{array}\right\}$ Inq. P.M. c. 1500.

Type II.

I086 $\left\{\begin{array}{l}\text { Mapleberg } \\ \text { Mapelberg }\end{array}\right\}$ D.B.

"The maple brook." From O.E. mapul(trēo), " maple (tree)," and O.N. bekkr, "brook, rivulet" (Type I). The small watercourse on which the village stands is now without an individual name.

Type II contains O.E. beorg, "hill, mountain," as second element. It is impossible to say whether this represents the original name which was later changed to the prevailing form. Mapelbeck is, as a matter of fact, situated at the foot of a hill which might very well have been called "the maple hill." It must, however, be mentioned here that the compilers of D.B. are by no means trustworthy guides in matters of etymology, as they too frequently employed the expedient of substituting more familiar forms for those with which they were not acquainted (see Bramcote).

MAPPLEWELL.

"The maple spring." The place probably takes its name from a spring in that locality, which is also famous for the petrifying qualities of its very cold and pure water. 
MARKHAM (East, or Great).

I086 Marcham, D.B.

MARKHAM (West).

I086 Westmarcham, D.B.

From O.E. mearc ham, "the home or dwelling on the boundary." The meaning of O.E. mearc was "boundary, mark, district"; it refers to the boundaries of states, but more frequently of fields and estates. The word mearc land was used to describe the waste land which often formed the boundaries of extensive clearings, and it is not impossible that the original Markham was situated on the confines of such a district. A political boundary may also have been implied, an assumption which is rendered likely by the fact that East Markham is situated on the watershed ridge of the Trent and Idle, and thus on a natural boundary which might easily have become a political one.

\section{MARNHAM.}

I086 Marneham, D.B.

\section{Type I.}

c. I 75 Marnaham, Woll. MSS.

I 302 Marnhame, F.A.

\section{Type II.}

c. I 190 Marisham $\left\{\begin{array}{l}\text { Coucher Book of Walley Abbey, } \\ \text { Cheetham Soc., I } 847, \text { p. } 5 .\end{array}\right.$

I take this name to stand for O.E. Māervines häm, "the homestead of Mēerwine," a pers. n. recorded in the Onomasticon. Type II represents the more natural development of the prototype, with the $\bar{a}$ shortened before $r w$, and subsequent loss of initial $w$ and $n$ before $s$ in the unstressed syllable. In Type I, which survived, the same changes took place with the one exception that the $s$ instead of the $n$ was dropped. It is very likely that the two types go back to two forms of different length, and therefore, stress, viz. the nominative and dative

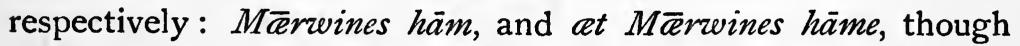
what the exact distribution of accents was I am at present unable to suggest (see Wyld, in Pl. Ns. of Oxf. pp. 5 sqq.). 
MARTIN or MORTON.

$$
\begin{aligned}
& \left.\begin{array}{l}
\text { I086 Martune, D.B. } \\
\text { I } 2 \text { I } 7 \text { Marton } \\
\text { I } 2 \text { 16-72 Martun }
\end{array}\right\} \text { Index. } \\
& \text { c. I } 500 \text { Marton, Inq. P.M. c. I } 500 .
\end{aligned}
$$

"The boundary farm or enclosure." The first element may

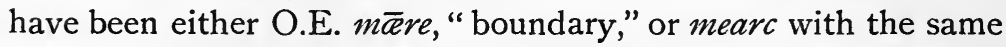
meaning. Although the $k$ would readily disappear between $r$ and $t$ (Phonology, $\S \mathrm{I} 2$ ), it is safer to adopt the former alternative in the absence of spellings containing a $c$ or $k$. The word $m \bar{e} r e$ is used exclusively of the boundaries of estates and fields. (Lancs. P1. Ns. p. 370.) What was the nature of the boundary here referred to, it is impossible to say. See Markham.

Both modern spellings are due to popular etymology: the first owes its existence to the analogy of the Christian name Martin, the second to that of the numerous pl.ns. Morton. There is, however, some phonetic justification for the former, as the unstressed vowel after dental consonants, and more especially if followed by another dental, is often pronounced $\check{\imath}$ in English dialects (Horn, $§$ I 49, $2 a$ ).

Martin forms the north-eastern hamlet of Harworth parish, adjoining Bawtry, which is situated in Yorkshire. The boundary between the two counties seems thus to go back to a very old division.

Mattersey or MAtTersea.

\section{Type $I$.}

I086 Madressei(g), D.B.

$\left.\begin{array}{l}\text { I } 278 \\ \text { I } 36 \\ \text { I } 428\end{array}\right\}$ Mathersey $\left\{\begin{array}{l}\text { H.R. } \\ \text { F.A. } \\ \text { F.A. }\end{array}\right.$

c. I 500 Mathersey, Inq. P.M. c. I 500.

\section{Type II.}

I 29I Marsey, Tax. Eccles.

I335 Mersey, Valor Eccles. 
Type III.

(a) c. I 500 Madersay, Inq. P.M. c. I500.

I 535-43 Madersey, Leland.

(b) c. I 500 Matteseythorp, Inq. P.M. c. I 500.

I 535 Matersey, Valor Eccles.

"The island or low-lying water meadow of Maðhere." The same personal name is contained in the Worcestershire pl. $\mathrm{n}$. Madresfield. The second element is O.E. éze.

Type I preserves the original most faithfully. The spellings under Type II show the regular loss of $\delta$ between vowels. If this form had survived one would expect the modern pronunciation to be [māzí]. Type III, which accounts for the modern spelling, arose out of the stopping of $\dot{\delta}$ before $r$ (III $a$ ); the $d$ thus produced was unvoiced during a later period, probably from a desire to vary the nature of the sounds which in this long word were all voiced.

The ending sea in the alternative modern spelling is an ingenious attempt at etymology.

The nature of the ground in the neighbourhood, as described by Leland, seems to be in accord with the meaning of the suffix. He says: "...and a Mile farther I saw the Course on the lifte hond of...Ryver, over the which I passid by a Bridge of...hard at the entering into Madersey Village. Thens I rood a Myle yn low wasch and sumwhat fenny Ground...."

MAUN or MAN (river).

I 300 Main(esheued)* Stevenson, Forest

I 332 Mamm(esheued)* ${ }^{*}$ Records, 399, 40 I.

I6r 3 Man, Drayton's Polyolbion.

c. 1900 Man, or Maun, Ordnance Map.

* i.e. head of river Maun.

The name of this river is derived from that of the town of Mansfield. Similar "back-formations" are enumerated by Dr Bradley in Essays and Studies, I, pp. 32, 331. The variations

1 "Thus Kimbolton, in Huntingdonshire, is derived from the personal name Cynebald; but the river on which the place stands has been provided by the mapmakers with the name Kim.... The name of the river Brain is a figment invented to account for Braintree." 
in spelling are explained under Mansfield (q.v.); ain for an is a peculiarly central French development; see Saundby.

\section{MEDEN (river) [mīdn].}

The termination may be the reduced form of an O.E. amma, or a similar word for "stream"; see Witham. I propose to connect the first part with O.E. $m \bar{a} d$, "meadow." The meaning "meadow stream" seems a most appropriate one for this particular water-course. A corresponding O.H.G. Madibah is recorded several times (Förstemann, II).

MEERING.

$$
\begin{gathered}
\text { Type I. } \\
\text { 1086 Meringe, D.B. } \\
\text { 1302 } \text { Meryng, F.A. } \\
\text { Type II. } \\
\text { 1 2 16-1 } 307\left\{\begin{array}{l}
\text { Meringes } \\
\text { Meriges }
\end{array}\right\} \text { Testa de N. }
\end{gathered}
$$

This is a patronymic name, which is proved by the forms of Type II. I believe this to have been O.E. (non-West-Saxon) Merrwingas, "the family or tribe of the Mérwings" (Type II), of which Type I is the dative pl. at Mérwingum.

This name is identical with that of the noble family of the Merovings, who as a dynasty preceded the Carolings in France and North-Western Germany. The original pers. n., of which this is the patronymic, must have been W. Germ. māru, "bright, famous" (see Hirt-Weigand, Deutsches Wörterb., s.v. Märe).

The Meringas are mentioned in an O.E. charter (Cod. Dipl. 809), and the same patronymic occurs in the O.H.G. pl. n. Maringen, modern Möhringen (Förstemann, II). The name Maring, Mering is frequent in the O.H.G. period, and is represented by the modern German surname Mehring.

Isaac Taylor, in his work entitled "Words and Places," refers to the Merovingians in connection with the above $\mathrm{pl}$. $\mathrm{n}$. and gives numerous references (ch. vII). 
MERRILS BRIDGE (West Drayton).

$\left.\begin{array}{l}\text { I225 de ponte Miriild } \\ \text { I } 316 \text { Mirielbrigge }\end{array}\right\}$ Bor. Rec.

"The bridge by the pleasant slope," O.E. sēo myrige helde, from myrig, modern "merry," here used in its old and original sense of "pleasant, delightful" as in "Merry England," and helde, West-Saxon hielde, "slope, declivity." The O.E. $y$ of the first syllable is represented by $i$ in the M.E. forms. The $e$ in the modern spelling may be the result of a peculiar dialect development of O.E. $y$, or may be due to the influence of the independent word, merry, which comes from the Kentish dialect.

For an explanation of the final $s$ see Brentshill.

Merrils Bridge is a very ancient structure situated at the foot of a gentle slope.

MIDDleTHORPE (under Caunton).

c. I 500 Midelthorp, Inq. P.M. c. I500.

I704 Midlethorp, Map.

The name explains itself.

Milnthorpe (under Norton).

Probably from M.E. milen thorp, " the mill thorpe or hamlet." The O.E. word for a mill is mylen. See Milton.

MiltoN or MILNETON.

\section{Type I.}

I278 Milneton, H.R.

c. I $500\left\{\begin{array}{l}\text { Milnton } \\ \text { Mylneton }\end{array}\right\}$ Inq. P.M. c. I 500.

Type II.

I086 Miletune, D.B.

Type III.

c. 1500 Molton, Inq. P.M. c. I 500.

O.E. mylen tīn, "the enclosure, or farmstead by the mill." See Milnthorpe.

Types II and III show loss or assimilation of $n$ between $l$ and $t$. The $o$ of Type III, which probably stands for $u$, may be due to a particular M.E. development of O.E. $y$ after labials. 
MiRfield HALL.

I take Mirfield to stand for O.E. se myrige feld, " the pleasant plain, or field." See Merrils Bridge for old meaning of myrige.

Misson (Mizon, Hope).

$$
\begin{aligned}
& \text { I086 }\left\{\begin{array}{l}
\text { Misna } \\
\text { Misne }
\end{array}\right\} \text { D.B. } \\
& \text { I278 Misin, H.R. } \\
& \text { I321 Mysyn }\} \text { Index. } \\
& \text { I379 Misen }\} \text { Ind } \\
& \text { I637 Masson, Map in Camden. }
\end{aligned}
$$

I cannot interpret this name. It seems to contain a rivername as first element; the $a$ and $e$ of D.B. seem to stand for older $\bar{e} a$, "river," so that the prototype would be O.E. at $M$...éa, "(the habitation) by the M...river." This e $a$ or $a$ would be lost subsequently as in Blyth (q.v.).

Camden seems to have blundered.

I cannot refrain from quoting the following delightful interpretation of the name contained in White's Directory (I853, p. 640): "Misson Parish lies...on the north side of the Idle, bounded on the west by Yorkshire, and on the east by Lincolnshire, and is partly in the latter county, which is here so intermixed with Nottinghamshire, that the boundaries of the two counties are almost indefinable, from which circumstance the parish is supposed to have been anciently called Misne or Myssen."

Misterton.

$$
\begin{aligned}
& 1086 \text { Ministretone, D.B. } \\
& 1278\left\{\begin{array}{l}
\text { Misterton } \\
\text { Mist'ton }
\end{array}\right\} \text { H.R. } \\
& \text { 1316 Misterton, F.A. }
\end{aligned}
$$

O.E. mynster tün, "the minster-town, or habitation by the church." The meaning of O.E. mynster is " monastery, nunnery, church, cathedral "; in this case it probably refers to an old preNorman structure. The loss of $n$ after initial $m$ may be due to dissimilation (Phonology, § 14 ).

Misterton in Leicestershire has the same origin; it appears as Minstertona in 1313 (Index). 
MORTON or MORETON (under Babworth).

$$
\left.\begin{array}{l}
1086\left\{\begin{array}{l}
\text { Mortune } \\
\text { Nordermortune }
\end{array}\right\} \text { D.B. } \\
\text { c. } 1200 \\
\text { I316 }
\end{array}\right\} \text { Morton }\left\{\begin{array}{l}
\text { Index. } \\
\text { F.A. }
\end{array}\right.
$$

MORTON (Fiskerton-with-Morton).

$$
\left.\begin{array}{l}
\text { I } 331 \\
1368 \\
1754
\end{array}\right\} \text { Morton, Index. }
$$

The meaning is obvious: "the tiun or habitation on the moor." The distinction made in D.B. seems to have been lost subsequently.

MUSKham (North and South).

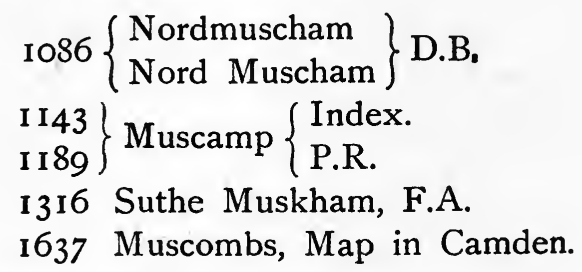

O.E. Muscan hām, "the home or dwelling-place of Musca." This pers. n. is not recorded in the Onomasticon. It must, however, have existed as it is found on the continent ; Förstemann (I) quotes from German documents Musco, Musgo, and refers to the modern German surname Musch. There is a pl. n. in Hesse exactly identical with the one under discussion: Muschenheim, from O.H.G. Muscanheim.

The same pers. n. seems to be contained in the Scandinavian pl. ns. Muskedalen, Musker $\phi d$ which are left unexplained by Rygh (N. Gaardnavne, p. 375). If the English name is not altogether of Norse origin, the retention of the pronunciation $s k$ must at any rate be ascribed to Scandinavian influence.

Camden again presents us with a fanciful spelling; he probably thought the name was connected with combe. The final $s$ is the sign of the plural, there being two villages of the same name.

The Index and P.R. forms betray Norman influence: the 
ending was taken to represent camp, the Norman-French descendant of Latin campus, frequently found in pl. ns. such as Fécamp.

NETHERFIELD.

"The lower field."

NetTleworth (under Warsop).

I I6-1307 Nettelwurd, Testa de N.

c. I500 Nettilworth, Inq. P.M. c. 1500.

I637 Nettleworth, Map in Camden.

"The enclosed homestead, habitation among the nettles"? There is no evidence either to prove or disprove this interpretation conclusively.

NEWARK-UPON-TRENT.

I066 Newarcha, Cod. Dipl. 878 (a starred charter).

I086 $\left\{\begin{array}{l}\text { Newerca } \\ \text { Neuuerce } \\ \text { Newerche }\end{array}\right\}$ D.B.

I $89\left\{\begin{array}{l}\text { Niwewerch, P.R. } \\ \text { Niwerch, Nott'm Charter. }\end{array}\right.$

1278 Newerk, H.R.

etc.

O.E. bat niuwe weorc, "the new fortification." The old fortifications, probably a continuation of Roman works, were destroyed by the Danes, but rebuilt in the reign of Edward the Confessor, when the place received its present name.

The meaning of the O.E. weorc, "fortification," is still preserved in the compound earth-work, and in the special military sense of "the works." Cp. also "out-works." The modern German Werk has the same sense.

For er $>$ ar see Phonology, $§ 7$.

NEWBOLD (under Kinoulton).

$$
\left.\begin{array}{c}
\text { Type I. } \\
\text { I086 } \\
\mathbf{1 2 8 4}
\end{array}\right\} \text { Neubold }\left\{\begin{array}{l}
\text { D.B. } \\
\text { F.A. }
\end{array}\right.
$$




\section{Type II.}

\section{$\left.\begin{array}{ll}\text { I I } 57 & \text { Niwebote } \\ \text { I I } 59 & \text { Niwebota }\end{array}\right\}$ P.R.}

O.E. pat niuwe botl, or bold, "the new dwelling." The noun appears in both forms botl and bold in O.E. (Sievers, $§ 183,2 a$ ), which accounts for the difference between Types I and II.

\section{Newington (under Misson).}

O.E. at $b \bar{e} m$ niuwan tüne, "at the new homestead." This name is found in all parts of England. For the change of unstressed an to ing see Phonology, § I3.

The same name in the nominative case sē niuwa tün is the prototype of the equally numerous Newtons.

\section{Newstead AbBey.}

1189 (Prior de) Novo Loco, Nott'm Charter.

I 205 Novus Locus in Shirewood, Cal. Rot. Chart.

c. I $500\left\{\begin{array}{l}\text { New Place } \\ \text { Newstede } \\ \text { Newstead }\end{array}\right\}$ Inq. P.M. c. 1500 .

The Priory, less correctly, Abbey of Newstead was founded in I I 70 by Henry II in what was then part of Sherwood Forest. Most probably the site had to be cleared of trees and undergrowth and was therefore called Novus Locus by the monks, though it is impossible to say whether this was a translation of a M.E. Nezwe stede or whether the latter was based on the original Latin name. The Nere Place of 1500 certainly looks as if it were a translation from the Latin; this variant may have been the form adopted by the Norman-French among clergy and nobility.

NEWTHORPE.

I086 Neutorp, D.B.

I34 I Neuthorp, Index.

This name requires no explanation.

M. 
NEWTON.
1086 Niwetune, D.B.
c. 1250 Neuton, Index.

O.E. sè niuwa tün, "the new homestead," see Newington.

NORMANTON-ON-SOAR.

$$
\text { IO86 }\left\{\begin{array}{l}
\text { Normantune } \\
\text { Normanton }
\end{array}\right\} \text { D.B. }
$$

NORMANTON-ON-TRENT.

$$
\begin{aligned}
& \text { I086 Normentune, D.B. } \\
& \text { I } 268 \text { Normanthon, Index. }
\end{aligned}
$$

NORMANTON-ON-THE-WOLDS.

I086 Normantone, D.B.

O.E. nortmanna tūn, "the enclosure or dwelling-place of the Northmen." These places owe their names not to the Normans but to their non-Frenchified kinsmen, the Scandinavian invaders. It might be urged against this that the suffix tim is AngloSaxon and not Norse in origin. We must, however, bear in mind that the pl. n. was invented and used by the original Anglo-Saxon inhabitants among whom the newcomers made their settlements; pl. ns. combining a Scandinavian pers. n. with an Anglo-Saxon designation of locality must be viewed in the same light.

The loss of $\delta$ between $r$ and $m$ is normal.

NORNEY (under Styrrup).

This place, of which there are no early spellings, is situated to the north of Blyth on a small river. I take it to stand for O.E. norterne e 3 e " the Northern brook, or island." The development would be as follows : norðrneje >norðnei > Norney.

Norton (in Cuckney Parish).

I 282 Norton, Bodl. Ch. and R.

"The north town, or habitation." This village forms the northern part of Cuckney. 
NORWELL.

I086 Nortwelle, D.B.

$1278\left\{\begin{array}{l}\text { Nortwell } \\ \text { Norwell }\end{array}\right\}$ H.R.

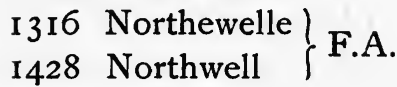

"The northern spring or brook."

Notown (under Bleasby).

As there are no early spellings it is impossible to attempt an explanation.

Nottingham [notigəm, Dial. Gramm. § 273] (Nottingum, Nottingyum, Nottinum, Hope).

\section{Type $I$.}

$\left.\begin{array}{c}868 \text { etc. } \\ 930\end{array}\right\}$ Snotingaham $\left\{\begin{array}{l}\text { A.S. Chron. passim. } \\ \text { Cod. Dipl. II, I70. }\end{array}\right.$

I086 $\left\{\begin{array}{l}\text { Snotingham } \\ \text { Snotingeham }\end{array}\right\}$ D.B.

c. I I 50 Snotingaham $\left\{\begin{array}{l}\text { Flor. of Worcester. } \\ \text { Symeon of Durham. }\end{array}\right.$

c. I250 Snotingham, MS. Jesus Coll. Oxon. (E.E.T.Soc. 49).

I 353 Snotyngham, Leicester Records.

\section{Type II.}

$\left.\begin{array}{l}\text { I } 3 \text { I } \\ \text { I } 153\end{array}\right\}$ Notingeham $\left\{\begin{array}{l}\text { P.R. } \\ \text { Index. }\end{array}\right.$

1278 Notingham, H.R.

c. I 300 Notingeham, Henry of Huntingdon.

$\left.\begin{array}{l}\text { I } 304 \\ \text { I } 336\end{array}\right\}$ Notingham $\left\{\begin{array}{l}\text { Index. } \\ \text { Leicester Records. }\end{array}\right.$

N.B. The majority of the early spellings quoted above are taken from Dr Zachrisson's book on “Anglo-Norman Influence on English P1. Ns." (pp. 5I, 52).

O.E. Snotinga hām, "the homestead of the family of Snot." The pers. n. Snot occurs as that of a tenant in D.B. The name Snothere is also recorded in the Onomasticon. There may have 
existed an O.H.G. pers. n. Snozo which seems to be contained in the pl. n. Snozindorf (Förstemann, I). The weak form of the O.E. name, * Snotta, survives in M.E. Snotte, the surname of a certain Peter mentioned in the Close Rolls (Cal. of Close Rolls, p. 570, quoted by Mr Stevenson).

Type I represents the native Anglo-Saxon form; Type II, with the initial $S$ dropped, owes its origin to Norman-French influence. Romance-speaking peoples find great difficulty in pronouncing certain initial consonant combinations of the Germanic languages. When a word was borrowed, such combinations were naturally got rid of, either by prefixing an $e$, or by inserting some vowel between the two consonants, or by simply dropping the obnoxious initial sound. The latter alternative was adopted when the Normans ${ }^{1}$ had to use the name of the O.E. Snotinga hãm, and that of the neighbouring Sneinton, which has a similar origin, being derived from O.E. Snotinga tün (see D.B. spellings under Sneinton). The fact that the clipped form survived in the former case only is accounted for by the circumstance that Nottingham, with its castle, became a most important stronghold of the conquerors, who settled in such numbers in the town that it had to be divided into two distinct communities, an English and a French one (see Zachrisson, pp. 5 I sqq.).

There still exists a general belief, even among people that ought to know better, that the name of the "Queen of the Midlands" signifies "the home of the caves." But however romantic and appropriate this interpretation ${ }^{2}$ may be, it will have to be abandoned. The notion is taken from a passage in Asser's "Life of King Alfred" (ed. W. H. Stevenson, M.A., Oxford, I904, p. 230), which reads: "Snotengaham...quod Britannice 'Tigguobauc' interpretatur, Latine autem 'speluncarum domus." "The learned editor of the text remarks that the

I Dr Bradley (E. and St. p. 39) facetiously remarks "that the people of Nottingham will bear them no ill-will' on this account."

2 I cannot refrain from quoting the following delightful explanation of the name given with the utmost assurance by Mrs Gilbert in her pamphlet entitled " Recollections of Old Nottingham" (p. 7): "Snottengham, from Snottenga (caves) and ham (home), subsequently softened into Nottingham." 
British name actually does mean "dwelling of the caves", or, more literally, "cavy house"; but this has nothing "tỏ do"with

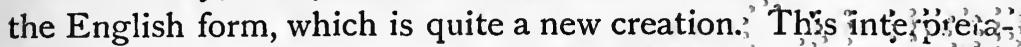
tion was later on eagerly seized upon by antiquaries, 'who mâde it the basis of fanciful elaborations in which they delighted, being concerned more with grotesque fiction than with sober facts. Camden in particular must be credited with having amplified and widely circulated the original mistake of King Alfred's biographer. The passage is so quaint and characteristic that it may find a place here: "Where, on the other banke <of the $\operatorname{Lin}\rangle$ at the very meeting well neere of $\operatorname{Lin}$ and Trent, the principall Towne that hath given name unto the Shire is seated upon the side of an hill now called Nottingham (by softning the old name a little) for Snottengaham; for, so the English Saxons named it of certaine caves and passages under the ground, which in old time they hewed and wrought hollow under those huge and steepe cliffs, which are on the South side hanging over the little River Lin, for places of receit and refuge, yea and for habitations. And thereupon Asserius interpreteth the Saxon word Sottengaham in Latine Speluncarum domum, that is, An house of Dennes or Caves, and in the British Tuiogobauc, which signifieth the very selfe same" (Camden, 547).

Nuthall or NutTall [natl].

$\left.\begin{array}{ll}\text { I086 } & \text { Nutehale, D.B. } \\ \text { 1284 } & \text { Notehall } \\ \text { I } 302 & \text { Notehale } \\ \text { 1316 } & \text { Notehall } \\ \text { 1428 } & \text { Notehale }\end{array}\right\}$ F.A.

O.E. on hnutu hĕale, "in the nut valley, in the vale where the nuts grow." Similar names, as hnut fen, hnut wic, are quoted by Middendorf from O.E. charters. This is one of the few names that show early substitution of hall for the second element. The principal modern spelling owes its origin to the same erroneous conception of the meaning of the ending.

The $o$ of all the F.A. forms stands for M.E. $u$ according to Norman-French practice (Sweet, N.E. Gr. $§ 775$ ). 
QLDCOATES or UlcoAtes (Alecotes, Hope).
Type I.
(d) $\left.\begin{array}{r}\text { I302 } \\ \text { I } 346\end{array}\right\}$ Oulecotes, F.A.
I 348 Oullecotes, Index.
I428 Oullecotez, F.A.
I 445 Owelcotes, Index.
(b) I 269 Ulcotes, Cal. Rot. Chart.
I278 Ulecotes, H.R.
I4I 4 Ulcotes, Index.
I 535 Ulcotts, Valor Eccles.

\section{Type II.}

I086 Caldecotes, D.B.

O.E. ülan cotas, "the houses of the owl, or near which the owl lives, is seen or heard." The vowel of the first syllable remains long in Type I $a$, ou or ow being the M.E. (NormanFrench) symbols denoting the long $u$-sound. This vowel is shortened before the combination $l k$ in Type $\mathrm{I} b$; from the latter the second modern spelling originates. The principal official form owes its origin to the interference of popular etymology. At some time or other the dialect pronunciation of the two words owl and old may have been very much alike, and may have caused the substitution of the latter for the former. The only information given by the Dial. Dict. is that M.E. $\bar{u}$ becomes [au] or [ā] in Nottinghamshire, whereas old is pronounced [ōd]. The transcription of the local pronunciation furnished by Hope is very ambiguous; if it is interpreted in accordance with the ordinary principles of modern English spelling, it would mean [eilkouts] or [êlkōts]. In spite of inquiries instituted in the locality itself a pronunciation deviating from the spelling could not be traced.

The D.B. form is without support. The scribe seems to have substituted a name with which he was more familiar. There is a Coldcotes in the West Riding. Dr Moorman interprets this as meaning "the cold cottages, on an exposed situation." Isaac Taylor (Words and Places, ch. $\mathrm{x}$ ) is of opinion, that this name like that of Cold Harbour (i.e. auberge) was given to certain structures erected on frequented roads, where travellers 
could obtain shelter but neither food nor fire ${ }^{1}$. When such a name belongs to a place not in the immediate neighbourhood of an ancient road, it seems to me to mean not "cottage on an exposed position," but "temporary building, house without a fire-place," such as one may still find in the fields used as barns and temporary shelters for cattle.

The Hessian pl. n. Eudorf is explained by Sturmfels (p. 2I) as meaning "Dorf, wo sich der Uhu gerne aufhält"-_village where the owl delights to dwell"; cp. O.H.G. hawo, huo; Awila, "owl."

OldWARK SPRING.

Stukeley, the antiquarian, found extensive Roman remains near this place. The meaning is therefore: "the spring near the old work or buildings." See Newark.

OLLERTON Or AlleRTON.

I086 Alretun, D.B.

$\left.\begin{array}{cc}\text { I I 89-99 } & \begin{array}{c}\text { Alretona } \\ \text { I } 190\end{array} \\ \text { Alretun }\end{array}\right\}$ Index.

I278 Alverton, H.R.

$\left.\begin{array}{l}\text { I } 3 \text { I6 } \\ \text { I } 377 \\ \text { I637 }\end{array}\right\}$ Allerton $\left\{\begin{array}{l}\text { F.A. } \\ \text { Index. } \\ \text { Map in Camden. }\end{array}\right.$

Probably from O.E. Alfheres tün, "the enclosure or homestead of Alfhere." The H.R. spelling of 1278 is the most valuable. It does not, however, enable us to say for certain that the pers. n. contained in the first element is Alfhere rather than either Alfred or Alfric or Alfweard.

The change from $a l$ to $a u l>\overline{o l}>o l$ is explained elsewhere (Phonology, § 9).

OMPTON.

I086 $\left\{\begin{array}{l}\text { Almuntone } \\ \text { Almentone }\end{array}\right\}$ D.B.

I216-1307 Alemunton, Testa de N.

$\left.\begin{array}{l}\text { I } 278 \\ \text { I } 316\end{array}\right\}$ Almeton $\left\{\begin{array}{l}\text { H.R. } \\ \text { F.A. }\end{array}\right.$

c. I 500 Elmeton, Inq. P.M. c. I 500.

1 Cp. the German pl. n. Kalter Herberg, older ze kalter herberge (dative) in the Eifel district, Rhenish Prussia. 
"The tün or homestead of Ealhmund." The development of the stressed vowel is similar to that in Ollerton (q.v.). It is noteworthy that in both pl. ns. the genitival $s$ of the first element is absent from all the recorded forms.

The spelling Elmeton shows the influence of the independent word elm-tree, with which it was connected by popular etymology.

ORDSALL.

I086 Ordeshale, D.B.
I 375 Ordesale, Index.
I637 Ardsall, Map in Camden.

I take this name to be derived from O.E. Ordrices healh, "the valley of Ordric." A person of the latter name is said in D.B. to have held land in this locality. It is possible that he gave his name to the village (see Gamston near Retford).

The phonetic development can be easily explained. Of the two $r$ 's the second one in the unstressed syllable was dropped (Phonology, § I4), whereas the fronted $c$ would become assimilated to the following $s$.

Camden's spelling means nothing.

ORSTON.

Type I.

$\left.\begin{array}{ll}1284 & \text { Orston } \\ 1428 & \text { Horston }\end{array}\right\}$ F.A.

c. I 500 Horson, Inq. P.M. c. I 500 .

I637 Ouston, Map in Camden.

\section{Type II.}

1086 Oschintone, D.B.

1242 Orskinton, Inq. P.M. I.

From O.E. Ordrīces tün, "the farmstead of Ordrīc." Type II arose out of confusion with Ossington (q.v.). The $d$ was lost between the two $r$ 's at an early period; the pers. $n$. itself occurs as Orric in O.E. The same name took a different line of change in Ordsall (q.v.). This variety of development may probably be accounted for by a different distribution of stress.

The initial $H$, which has no significance in this dialect, may 
represent an attempt at connecting the name with horse. Camden's form and that of 1500 are interesting in so far as they may represent the contemporary pronunciation.

OSBERTON (under Scofton).

\section{Type $I$.}

I086 Osbernestune, D.B.

1428 Osberton, F.A.

1637 Osburton, Map in Camden.

$$
\text { Type } I I \text {. }
$$

c. I 500 Esbarton, Inq. P.M. c. I500.

O.E. Osbeornes tün, "the farmstead of Osbeorn." This pers. n. is of Scandinavian origin. Its prototype was $\bar{A} s b i o r n$, but when it was introduced into England, it became anglicised in form, the $\bar{a}$ (from $a$ before $n s$ ) being changed to $\bar{o}$ and io to $e o$. Type II contains another Norse variant of the same pers. n. Asbiorn (see Björkman, p. 10). It is curious to meet Type II in so late a document only; this seems to indicate that the scribes of the I 5 th century must have had access to old and reliable sources, and that tradition in the spelling of pl. ns. was very strong.

The complete disappearance of the genitival $s$ is a noteworthy feature of this name. The various forms assumed by $e$ before $r$ are explained elsewhere (Phonology, $\S 8$ ).

OSMONDTHORPE (under Edingley).

I086 Oswitorp', D.B.

I33 I Osmundthorp, Index.

c. I 500 Ossonthorpe, Inq. P.M. c. I 500.

"The dwelling-place or hamlet of Osmund." This pers. n. is found both in O.E. and O. Norse, in the latter language as $\bar{A}$ smundr, which, however, would readily assume the English form (see preceding name). The nature of the second element speaks in favour of Norse origin (see Björkman on Asmund, p. 2 I).

The spelling of A.D. I 500 evidently represents the contemporary pronunciation, with $m$ dropped in the beginning of an unstressed syllable.

1 Evidently a misreading; the scribe mistook Osmutorp for Osuuitorp. 
OSSINGTON.

I086 Oschintone, D.B.

I 73-4 Oskinton, P.R.

I216-72 Occington, Index.

I 278 Oscington, H.R.

1327-77 Ossyngton, Non. Inq.

"The tün or farmstead of Osketin." This is the Scandinavian pers. n. $\bar{A}$ sketill, of which numerous examples are found both in the original and the new domains of the Norsemen. The change from $\bar{a}$ to $\bar{o}$ is accounted for by the fact that the element $\bar{a} s$ was found as $\overline{o s}$ in native Anglo-Saxon names (see preceding name). The substitution of the ending in for ill is explained by Dr Björkman (p. I7) as due to confusion of the two Latin suffixes inus and illus. A similar transformation is noted by Professor Wyld, who finds the pers. n. Roskin for Rosketill in the Lancs. pl. n. Rossendale.

The phonetic changes are regular (see Phonology, \$ I ; I3). This name furnishes another instance of the transition of unstressed in to ing (Phonology, § I 3 ).

OSWARDBECK (Wapentake).

\section{Type $I$.}

$\operatorname{I086}\left\{\begin{array}{l}\text { Oswardebec Wap. } \\ \text { Wardebec Wap. }\end{array}\right\}$ D.B.

I 53 Oswardebec, Index.

I 89 Oswardesbech, P.R.

$1278\left\{\begin{array}{l}\text { Oswardebeck } \\ \text { Hoswordbec }\end{array}\right\}$ H.R.

Type II.

1 2 16-1307 $\left\{\begin{array}{l}\text { Oswaldebeck } \\ \text { Oswoldebeck }\end{array}\right\}$ Testa de N.

I444 Oswaldbeck, Index.

No attempt has been made to classify or discuss the variety of spellings found in the Inq. P.M. c. I500. They afford an instructive example of what divergent results the united actions of phonetic tendencies and popular etymology may produce: 
Oswaldbeck, Osberbeksoke, Hoswoldbekesoke, Oswalbeke, Oswardbek, Osilbeke, Ossonbek, Osbaldbekoop, Walbeksoken, Osylbeke.

This wapentake derives its name from a brook called Osweardes bekk, "the brook of Ösweard" (Type I). As the second element is of Norse origin, O.N. bekkr, we may perhaps infer that the pers. $n$. was originally of the same origin. There exists a Scandinavian pers. n. $\bar{A}$ svardr $r$, of which traces are found in England (cp. Björkman, Index), and for which the native equivalent $\bar{O}$ sweard might have easily been substituted (see preceding names, and, on the subject of substitution in general, Björkman, pp. 197 sqq.).

In Type II the pers. n. Ōsweald is erroneously introduced.

OWTHORPE.

\section{Type I.}

I086 Ovetorp, D.B.

c. I 190 Hustorp, Woll. MSS. (queried by the editor). I216-1307 Uvetorp, Testa de N. 1302 Outhorp, F.A.

\section{Type II.}

$1284\left\{\begin{array}{l}\text { Cupehoip } \\ \text { Cupthorp }\end{array}\right\}$ F.A.

"The thorpe, or dwelling-place of $\bar{U} f$, or $\bar{U} v i$." The name is Norse in origin; Dr Björkman quotes several instances of its occurrence in England. The $v$ became vocalised after the $\bar{u}$. The initial $h$ of the Woll. MSS. spelling means nothing (Phonology, § 19). I cannot explain Type II; it must have arisen out of a blunder of the scribe.

OXTON.

$$
\begin{aligned}
& \text { I086 } \left.\begin{array}{l}
\text { Oxetune } \\
\text { Ostone }
\end{array}\right\} \text { D.B. } \\
& \text { I } 278 \text { Oxton, H.R. } \\
& \text { I } 292 \text { Oston, Index. } \\
& \text { I } 302 \text { Oxton } \\
& \text { I } 316 \text { Hoxton } \\
& \text { I } 346 \text { Oxton }
\end{aligned}
$$

"The ox-enclosure." The name needs no further explanation. 
PAPPLEWICK.

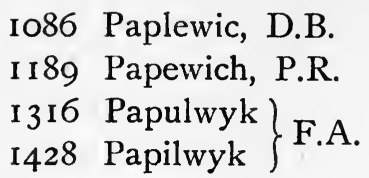

O.E. papol wic, "the pebbly creek or bay." The village is situated on the eastern bank of the river Leen.

The second element, which is of Norse origin, is discussed under Colwick. papol(-stān) means "pebble" in O.E.

Perlethorpe or Palethorpe (Palethorpe, Hope).

I086 Torp, D.B.

I I66-7 Peurelestorp, P.R.

I 278 Pevereltorp, H.R.

Peverltorp, Inq. P.M. II.

I316 Peverelthorp, F.A.

I637 Parlethorp, Map in Camden.

"The thorpe or village owned by the noble family of Peverel." The Peverels came over to England with the Conqueror, but apparently did not obtain land in Nottinghamshire until after the date of the Doomsday survey. Many places appearing simply as Torp in D.B. have later acquired a distinctive addition from the name of the then owner, usually a Norman nobleman, as Thorpe Basset, Thorpe Mandeville etc. It is rare, however, to find a Norman name prefixed in true Teutonic fashion as in the present name. A similar instance is found in Cossardthorpe, an ancient name for Hodsock which has not survived.

The curious development of the stressed vowel, erl $>a r l>\bar{a} l$ $>$ eil is a peculiar feature of the dialect (see Phonology, $\S 7$ ).

The first modern spelling preserves an older type, whereas the second is phonetically correct.

Plumptree.

1086 Pluntre, D.B.

I 302 'Plumtre, F.A.

I460 $\left\{\begin{array}{l}\text { Little Plumptree } \\ \text { Parvus Plomptre }\end{array}\right\}$ Index.

I637 Plumbre, Map in Camden. 
O.E. at plüm trēorve, "at the plum-tree." In O.E. charters, trees are often referred to in connection with boundary marks and field names. The medial $p$ represents the labial glide which developed between the $m$ and the $t$ (Phonology, $\S-16$ ).

POUlter (river) [pautə].

RADCLIFFE-ON-TRENT [rætlif].

\section{Type $I$.}

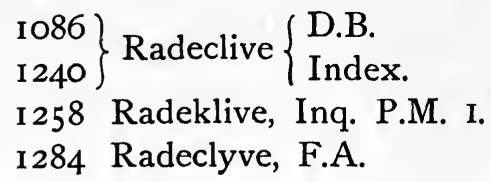

\section{Type II.}

I29I Radeclyf super Trent, Tax. Eccles.

1428 Radclif, F.A.

I637 Ratclyf, Map in Camden.

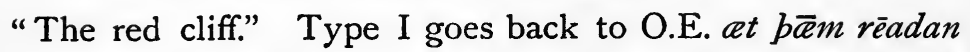
clife, whereas Type II, from which the modern spelling is derived, stands for the nominative bat réade clif. The village is situated on a lofty red cliff on the southern bank of the Trent. There is another place of the same meaning in this county (see Ratcliffe) and a Radcliffe in Lancashire. Corresponding German names also occur, as Rothenfels (Baden), O.H.G. Roten$v e l s$, and Rodestein, called $z i$ themo roten stenni in the older language (Förstemann, II).

The O.E. $\bar{e} a$ was shortened at an early period before it had changed to M.E. $\bar{e}$ (Phonology, $\S \mathrm{I}$ ). In the combination $d k l$, the $k$ caused the unvoicing of the preceding dental, after which it was dropped (Phonology, $§ 17$; 12).

RADFORD (in Nottingham).

\section{Type I.}

I086 Redeford, D.B.

\section{Type II.}

c. 1240 Radeford, Bodl. Ch. and R.

I637 Radforde, Map in Camden. 


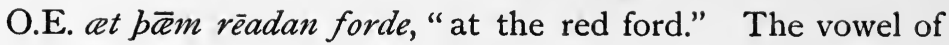
the first element appears long in D.B. $(e$ in open syllable $=[\bar{x}]$, Stolze, $§ 19)$, but was later shortened before the combination $d f$ (Type II). Retford in the north of the county has the same meaning; both places are situated on small water-courses just inside a stretch of Bunter sandstone. Especially in the neighbourhood of Radford the red colour of certain cliffs and of the river-bed is noticeable. It must have struck those coming out of the adjoining Keuper regions in particular as characteristic of the locality. There is a German pl. n. Rotenförde (Province of Saxony), older Low Germ. Rodemfuordi (Förstemann, II).

See Retford, and remark by Professor Wyld on Radcliffe (Lancs. Pl. Ns.).

RAGNALL.

Type $I$.

I086 Ragenehil, D.B.

I I6-72 $\left\{\begin{array}{l}\text { Ragenil } \\ \text { Ragenhil } \\ \text { I } 329 \\ \text { Ragenhill }\end{array}\right\}$ Index.

Type II.

I 287 Reynilthorp, H.R.

It is impossible to explain this name satisfactorily. The second element may originally have been borp, and the first a Scand. pers. n., either Ragnald or Regnald. The early spellings seem to show substitution of the Norse female name Ragnhild or Regnhild. (See Björkman, pp. III, II2.) The confusion of the syllable -all $(<$ ald $)$ or -hill $(<$ hild $)$ with the frequent second theme O.E. health or hyll respectively may have led to the substitution of the latter and the dropping of what would then appear as a third element -thorp.

RAINWORTH (under Blidworth).

The second element is O.E. weorb, worb, "enclosed homestead, habitation." I cannot explain the first part, as there are no early forms. It may represent an old Celtic river-name (cp. the German river-names Rhein, Regen), or the first element of an O.E. pers. n. beginning with Regin-, such as Regenbeald, Regenheard etc. 
RAMPTON.

$$
\begin{aligned}
& 1086\left\{\begin{array}{l}
\text { Rampestune } \\
\text { Rametone }
\end{array}\right\} \text { D.B. } \\
& \left.\begin{array}{l}
1302 \\
1637
\end{array}\right\} \text { Rampton }\left\{\begin{array}{l}
\text { F.A. } \\
\text { Map in Camden. }
\end{array}\right.
\end{aligned}
$$

"The tün or homestead of Hrafn." This Scandinavian pers. n. is found in various forms in English records, as Rafn, Raven, Ram etc. The latter type, with the articulations of $f$ and $n$ combined into $m$, is contained in the above pl. $\mathrm{n}$. The development of a labial glide between $m$ and $t$ is a natural and regular process (Phonology, § I6).

RANBY.

$$
\begin{aligned}
& \text { I086 }\left\{\begin{array}{l}
\text { Ranesbi } \\
\text { Ranebi }
\end{array}\right\} \text { D.B. } \\
& \text { I316 Raneby, F.A. }
\end{aligned}
$$

"The $b \bar{y}(r)$ or dwelling of Hrafn." The same pers. n. forms the first element of the preceding and following names.

RANSKILL.

$$
\begin{array}{ll}
\text { I086 } & \text { Raveschell, D.B. } \\
\text { I278 } & \text { Ravenskelf, H.R. } \\
\text { I704 Rawkild, Map. }
\end{array}
$$

"The well of Hrafn." The second element is Scandinavian kelde, " a well," which is discussed under Bothamsall (q.v.). The pers. $\mathrm{n}$. appears in the same form as in the preceding pl. $\mathrm{n}$.

The H.R. spelling substitutes O.N. skjalf, older *skelf, "a shelf, ledge, seat," for the original termination. This skjalf occurs in the Yorks. pl. n. Ulleskelf, "the ledge of Ulfr" (see P1. Ns. of the W. Rid.).

aw in the spelling of 1704 seems to be the result of the vocalisation of $v$ after $a$; or is it a mistake?

In the modern form, $v$ has disappeared before $n$ according to rule.

RATCLIFFE-UPON-SOAR.

\section{Type $I$.}

1086 Radeclive, D.B.

I 189-99 Radeclivam super Soram, Index.

1284 Radeclyve, F.A. 


\section{Type II.}

I29I Radeclif super Soram, Tax. Eccles.

I637 Radclyff, Map in Camden.

Thoroton (I, 24) explains this name as meaning "Red Hill or Bank."

See Radcliffe above.

REMPSTON.

I086 Repestone, D.B.

I 55-65 Rempestuna(m), Nott'm Ch.

I 302 Rempeston, F.A.

1327-77 Remeston, Non. Inq.

1637 Remston, Map in Camden.

"The tün or homestead of Reven." This pers. n. is a variant of Raven, from an original Scandinavian Hrafn. The development is similar to that of the same element in Rampton (q.v.), with this one exception, that in the present case the sign of the genitive has been preserved. Thoroton gives an alternative spelling Rampeston which shows that the two types of the pers. n. were interchangeable.

RETFORD (East and West) (Redfud, Hope).

Type $I$.

1086 Redforde, D.B.

$\left.\begin{array}{c}\text { I225 } 227-77\end{array}\right\}$ Retford $\left\{\begin{array}{l}\text { Bor. Rec. } \\ \text { Non. Inq. }\end{array}\right.$

1278 Retteford, H.R.

I29I Retford, Tax. Eccles.

I316 Retteford, F.A.

I 535 Redforth, Valor Eccles.

I704 Redford, Map.

Type II.

$\left.\begin{array}{l}\text { I } 155^{-65} \\ \text { I } 89\end{array}\right\}$ Radeford, Nott'm Ch.

"The red ford." See Radford, which has the same meaning. The divergence of types is explained there. $d$ has become $t$ under the influence of the voiceless $f$. The late spellings 
containing $d$ are due to attempts at etymological correctness. The suffix -forth of the Valor Eccles. is introduced from other pl. ns. which contain the Scandinavian fjoror instead of the English -ford.

White's Directory (1853, p. 660) says that "the two Retfords were named after the ancient ford which crossed the Idle a little below the bridge which now unites them, and was called the red ford from its stratum of red clay being so frequently disturbed by the passage of cattle etc., as to tinge the water with its colour."

\section{ROCKLEY (under Askham).}

The second element seems to be O.E. lëah, "field, meadow." It is impossible to say what the first stands for ; it may go back to O.E. hrōc, "rook (bird)," or M.E. roc, "rock," or it may contain the Scandinavian pers. n. Hrökr, found as Roc in England.

ROLLESTON [roulstn].

I086 $\left.\begin{array}{l}\text { Roldestun } \\ \text { Rollestone }\end{array}\right\}$ D.B.
I I89 Rodeston, P.R.
I 287 Rolliston, H.R.
I302 Roldeston
I428 Rolleston $\}$ F.A.
I637 Rowlston, Map in Camden.

"The tün or farmstead of Rold." This pers. n. is an abbreviation of the Scandinavian Hrōaldr (Björkman, p. 69). ld has become $l l$, after which change an $u$-glide developed between $o$ and ll (Phonology, \$§ I3;9). The latter change is recognised by Camden but not in the modern spelling.

RUDDINGTON.

Type $I$.

I086 $\left\{\begin{array}{l}\text { Roddintone } \\ \text { Rodintun }\end{array}\right\}$ D.B.

c. I 190 Rudingtun, Woll. MSS.

I428 Rodyngton, F.A.

I637 Reddington, Map in Camden.

M. 


\section{Type II.}

I 227-77 Rotington, Non. Inq.

I 26I Rotinton, Inq. P.M. I.

I29 I Rotington, Tax. Eccles.

I 302 Rotynton, F.A.

The first element is a patronymic in the genitive plural, derived from the O.E. pers. n. Rudda. The meaning of O.E. Ruddinga tün is therefore "the homestead of the family of Rudda, the Ruddings" (Type I). A similar O.E. pers. n., Ruta, is contained in Type II ; there must have been confusion between these two names. Camden evidently connects the name with red-another instance of his unrestrained etymological imaginativeness.

RUFFORD.

Type $I$.

(a) 1086 Rugforde, D.B.

I 55 Rūford, P.R.

(b) I 56 Rufford, Index.

I 278 Rafford, H.R.

I29I Rufford, Tax. Eccles.

(c) Rumford, Monasticon Anglicanum.

Type II.

I 56 Rudford, P.R.

I275 Ruthford, H.R.

Type III.

$\left.\begin{array}{ll}\text { I I63 } & \text { Rucford } \\ \text { I I98 } & \text { Rocheforde }\end{array}\right\}$ P.R.

I637 Rucheforde, Map in Camden.

It is evident from the spellings under Type I $a$, that the first element is O.E. rīh, "rough." The meaning therefore is "the rough ford." The adjective may indicate either that the water was turbulent, or, more probably, that the ford was difficult to cross. There is a Rufford in Lancs., and a Rufforth in the West Riding.

The original $h$ has become assimilated to the following $f$ 
(Type I $b$ ). Before the long $f$, the $\bar{u}$ was shortened. Type I $c$ represents the O.E. dative $a t r \bar{u}(w u) m$ forde (or $a t b \overline{\boldsymbol{e}} m$ rü(wa)n forde, with change of $n f$ to $m f$ through assimilation). The other types owe their origin to the peculiarities of Norman-French pronunciation. The sound of $h$, the guttural spirant, was unknown to the Normans, so they substituted $k$ for it, as Englishmen will do at the present day with regard to German ch after back vowels. The $c h$ of Type III stands for the sound of $k$ as in many Norman records (Zachrisson, pp. 32 sqq.). By other Normans, the unfamiliar spirant was mistaken for the, to them, equally troublesome $\delta$, which accounts for Type II.

The late appearance of Camden's form must be explained by assuming that he copied from an old source.

\section{RUSHCLIFF (Wapentake).}

$\left.\begin{array}{ll}\text { I086 } & \text { Riseclive, D.B. } \\ \text { I } 284 & \text { Riseclyve } \\ \text { I302 } & \text { Ryseclive } \\ \text { I428 } & \text { Rysshclyve }\end{array}\right\}$ F.A.

This name needs no translation. Cliffs and mounds were favourite sites to hold meetings on (see Bassetlazw). The second element of the early spellings appears in the dative (see Ratcliffe).

The vowel of the O.E. hrysce is correctly represented by M.E. $i$ in the above forms. The $u$ of the modern spelling is due to the influence of the independent word, rush, introduced into the standard language from another dialect.

It may be mentioned here that the sound of $s h$ (from O.E. $s c$ ) is very frequently represented by $s$ in D.B. and other Norman records (Stolze, $§ 42$ ).

\section{SALTERFORD.}

I086 Saltreford, D.B.

This name may stand for O.E. sealtera ford, "the ford of the salt-dealers." The manufacture and distribution of salt were of great importance in ancient times. Salt-springs, salinae, and "salt-streets" are frequently mentioned in mediæval records 
(see Crawford Charters, p. II 5). There is another Salterford in Worcestershire of apparently the same origin. Although the Notts. Salterford was situated in the very heart of the desolate forest, it is yet possible that one of the prehistoric cross-country tracks passed through the neighbourhood, and that this was frequented by salt-carriers.

Isaac Taylor (Engl. Village Names, $§ 5$ ) derives this name from a hypothetical sealh tréo ford, " the ford by the sallow-tree." It is impossible to say which of the two explanations is the correct one.

SAUNDBY.

$$
\begin{aligned}
& \text { Type } I \text {. } \\
& \left.\begin{array}{l}
\text { I086 } \\
\text { I } 89
\end{array}\right\} \text { Sandebi }\left\{\begin{array}{l}
\text { D.B. } \\
\text { P.R. }
\end{array}\right. \\
& \text { Type II. } \\
& \left.\begin{array}{l}
\text { I } 278 \\
1346
\end{array}\right\} \text { Saundebi }\left\{\begin{array}{l}
\text { H.R. } \\
\text { F.A. }
\end{array}\right. \\
& \text { c. } 1500 \text { Saunby, Inq. P.M. c. } 1500 \text {. } \\
& \text { Type III. } \\
& 1428 \text { Saindeby, F.A. }
\end{aligned}
$$

Type I represents the original most faithfully. The first element may have been O.E. sand, "sand," so that the meaning would be "the sandy habitation."

I am, however, inclined to think that the Norse pers. $n$. Sandi is involved, of whose occurrence in England Dr Björkman (p. I 16) gives one instance. The same name occurs as Sanda in O.E. and as Sando in O.H.G.

Norman influence is responsible for the change from an to aun in Type II which has survived (Phonology, $\S$ I I). ain from an represents a Central French sound-change; cp. French pain $<$ *pane, laine < lana etc. (Schwan-Behrens, Grammatik des Altfranzösischen ${ }^{6}$, I903, $§ 53$, I $a$ ).

SAXONDALE or SAXENDALE.

$$
\text { Type } I \text {. }
$$

I086 Saxeden, D.B. 


\section{Type $I I$.}

1284 Saymdall, (?) F.A.

I29I Saxindal, Tax. Eccles.

$\left.\begin{array}{l}\text { I } 302 \\ 1472\end{array}\right\}$ Saxendale $\left\{\begin{array}{l}\text { F.A. } \\ \text { Index. }\end{array}\right.$

c. I $500\left\{\begin{array}{l}\text { Saxondale } \\ \text { Saxendall }\end{array}\right\}$ Inq. P.M. c. I 500.

I637 Saxindale, Map in Camden.

\section{Type III.}

c. I 500 Saxbye, Inq. P.M. c. I 500.

It is impossible to say what the O.E. prototype of this name was. Whereas the second element of Type I is of O.E. origin, Type II, which survived, contains its Norse equivalent, both denu and dalr meaning the same thing, viz. "valley." The third type contains another Norse word, $b \bar{y} r$, "habitation, village."

The first element, too, is of doubtful origin. There are three possibilities ; it may stand for: (I) the genitive of O.E. Seaxe, "Saxons," which was Seaxna (Sievers, $\$ 276$, anm. $3 a$ ); (2) the genitive of the O.E. pers. n. Seaxa, or (3) of the Scandinavian pers. n. Saxi.

Interchange of the suffixes den and dale is also found in the early forms of the Lancs. pl. ns. Skelmerdale and Ainsdale.

SCAFTWORTH.

I086 Scafteorde, D.B.

1227-77 Skaftwurth, Non. Inq.

I 278 Skastewurh, H.R.

c. I $500\left\{\begin{array}{l}\text { Skastworth } \\ \text { Scastworth } \\ \text { Scarworth (!) }\end{array}\right\}$ Inq. P.M. c. I 500.

"The weorb or farmstead of Skafti." The pers. n. is of Norse origin as is proved by the initial sk. If the O.E. corresponding form Sceaft (Onomasticon) were contained in this name, the initial $S c$ would be pronounced $s h$. It is, however, quite possible that the O.E. form was the original one for which the Scandinavian equivalent was substituted later on. 
The name Skapti is not recorded by Dr Björkman as found in England. It occurs frequently in Iceland (cp. Landn. Bōk, 79) and also in Norway (Rygh, G. Personnavne, p. 219).

In the above spellings, $s t$ may be due to a misreading, the original $f$ being taken for the long $s$. Are the modern editors responsible for this blunder?

SCARLE.

I086 $\left\{\begin{array}{l}\text { Scornelei, D.B. (Victoria County History). } \\ \text { Scorvelei, D.B., as transcribed by Thoroton. }\end{array}\right.$

I 227-77 Southscharle, Non. Inq.

I316 Scarle, F.A.

The second element is O.E. lēah, "field." The first seems to stand for a pers. n. If the D.B. spelling as read by Thoroton is correct, it represents the O.E. pers. n. Sceorf. The later spellings and the modern form cannot, however, be directly descended from an O.E. Sceorfes lēah. The initial sk clearly points to Scandinavian influence (cp. preceding name). One is, therefore, compelled to assume that the Scandinavian pers. n. Skarf (Björkman, p. 122) was substituted, which also accounts for the change in vowel.

$v$ was lost between $r$ and $l$ as the result of a general tendency (Phonology, § I2).

SCARRINGTON.

I086 Scarintone, D.B.

I 242 Scherinton, Inq. P.M. I.

I637 Sharinton, Map in Camden.

The first element seems to be the genitive plural of some patronymic, of Scandinavian origin, as is clearly shown by the initial sk. The recorded spellings are insufficient to form an opinion as to the name involved: it may have been Skarf (Björkman, p. 122) or Skardi (Rygh, G. Personnavne, p. 220).

SCOFTON.

\section{I086 Scotebi, D.B.}

The initial $s k$ proves that the first element is a Scandinavian pers. n., most probably Skopti, recorded by Rygh (G. Personnavne, p. 225). The meaning therefore is "Skopti's farmstead." 
SCREVETON [skritn].

Type I.

I086 $\left\{\begin{array}{l}\text { Screvetone } \\ \text { Screvintone } \\ \text { Escreventone }\end{array}\right\}$ D.B.

I 302 Screveton, F.A.

\section{Type II.}

c. 1500 Screton, Inq. P.M. c. 1500.

I 535 Scretton, Valor Eccles.

Type III.

I284 Scrouton, F.A.

1637 Skiwton (?), Map in Camden.

The first element must be of Norse origin as is demonstrated by the initial $s k$ (cp. Scaftworth). It probably represents the genitive of a pers. $\mathrm{n}$. following the weak declension. What this name was, I am unable to say. Type III cannot easily be reconciled with the rest.

SCROOBY.

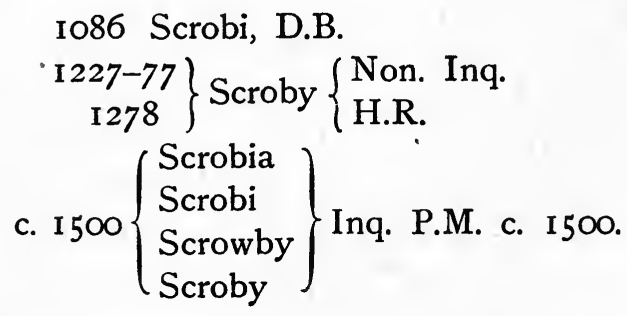

The first element may contain the O.N. pers. n. Skorri, which Dr Björkman finds in the pl. ns. Skorreby, Scorby, Skorton (p. 124). Metathesis of $r$ frequently occurs in this dialect (Phonology, § I5). The meaning is, therefore, "Skorri's farm, or hamlet."

The modern spelling is misleading. It perpetuates a M.E. habit of writing $o o$ both for O.E. $\bar{o}$, and $\bar{q}$ from $o$ in open syllable. One would expect the pronunciation to be [skroubi]. 
Selston.

I086 Salestune, D.B.

$$
\begin{aligned}
& \left.\begin{array}{l}
\text { I } 284 \\
\text { I } 29 \text { I }
\end{array}\right\} \text { Seliston }\left\{\begin{array}{l}
\text { F.A. } \\
\text { Tax. Eccles. }
\end{array}\right. \\
& \text { I } 3 \text { I } 6 \text { Selleston, F.A. }
\end{aligned}
$$

The first element seems to be a pers. $n$. in the genitive case; perhaps O.E. Selua, or Scand. Seli( $r)$ ?

Serlby (Sarl-by, Hope).

$$
\begin{array}{ll}
\text { I086 } & \text { Serlebi, D.B. } \\
\text { I302 } & \text { Serleby, F.A. } \\
\text { I637 } & \text { Surlbye, Map in Camden. }
\end{array}
$$

"The $b \bar{y}(r)$ or farmstead of Serlo." The suffix as well as the pers. n. are from O. Norse. Dr Björkman (p. I I7) refers to this pl. n. as containing the above Scandinavian pers. n.

For the development of er into ur, ar, see Phonology, $\$ 7 ; 8$. SHELFORD.

$$
\begin{aligned}
& \text { I086 Scelforde, D.B. } \\
& \left.\begin{array}{l}
\text { I } 278 \\
\text { I } 284
\end{array}\right\} \text { Schelford }\left\{\begin{array}{l}
\text { H.R. } \\
\text { F.A. }
\end{array}\right.
\end{aligned}
$$

The name Sceldfor is found on a coin struck about the year 890 , and it is conjectured that this stands for the above pl. n. (Onomasticon, s.v. Sihtric comes). If this is correct, the etymology at once becomes clear. There existed in O.E. the adjective sceald, W.S. scield, "shallow," which appears in M.E. as shoal, from the Anglian type (see Napier and Stevenson, Transactions of the Philol. Soc. 1895-8, 532; Ekwall, Beibl. z. Anglia, Xx, 209; Schlutter, Engl. Stud. 43, 3 I8). I assume that by the side of the West Germanic adjective skalða- there existed also a form skal\$ja-, which would produce Anglian scelde (Bülbring, $\$ 175$ anm.). The relation between the two types would be the same as that between O.E. smolt and smylte, "quiet," strong and strenge, "strong," etc. (Sievers, § 299, anm. I).

I take, therefore, the above name to stand for O.E. (Anglian) at $p \overline{\bar{e}} m$ *sceldan forde, "at the shallow ford." After the disappearance of the adjectival ending, $d$ would drop in the combination ldf.

The name Scealdan ford, "at the shallow ford," occurs in an O.E. charter (Cart. Sax. 758; 802). Searle is certainly wrong in 
explaining the first element as a pers. $n$. The unmutated form of the adjective, from *skalsa-, seems to be contained in the modern pl. n. Shalford in Surrey.

The corresponding form of the mutated adjective seems to be contained in the Hessian name Schöllenbach.

The following description of the neighbourhood is calculated to support the proposed etymology: "Shelford...is a pleasant village on a gentle eminence, which in very great floods is sometimes completely surrounded by the Trent water...though it is distant half a mile from the regular channel of the river..." (White, Directory, 1853, p. 455). The Trent has evidently changed its course in this locality.

SHELTON.

$$
\begin{aligned}
& \left.1086 \begin{array}{l}
\text { Sceltun } \\
\text { Sceltone }
\end{array}\right\} \text { D.B. } \\
& 1302 \text { Schelton, F.A. } \\
& \text { 1637 Shilton, Map in Camden. }
\end{aligned}
$$

The village is situated on a ridge overlooking the river Smite. I am, therefore, inclined to connect the first element with O.E. (W. Sax.) scylfe, Anglian scelfe, "shelf, ledge." The meaning, therefore, is "the tün or homestead on the ridge."

SHERWOOD FOREST.

I 89 Schirewude, P.R.

1272 Syrewde forest, Inq. P.M. I.

I 278 Shirwod, H.R.

I393 Shyrewode, Index.

I637 $\left\{\begin{array}{l}\text { Shirewood, Camden, p. } 547 . \\ \text { Sherewood, Map in Camden. }\end{array}\right.$

Camden says that "some expound [this name] by these Latin names Limpida Sylva, that is, A Shire or Cleere wood; others Praelara Sylva, in the same sense and signification" (p. 550). It seems highly improbable, however, that it has anything to do with the O.E. adjective scir, "bright, pure." When the name was first given, the mediæval mind had not yet awakened to a sense of the beauties of the primeval forest. On the contrary, large and dense woods such as this one inspired superstitious fears; they were regarded as inimical to civilisation, 
the seat of man's worst enemies: "vasta solitudo,...saltus ferarum et cubile draconum" are the terms used by a German monastic chronicler ${ }^{1}$ in reference to a wood near Berchtesgaden.

Others connect the first element with modern shire. In the earliest records, Sherwood is often spoken of as the "forest of Nottingham" (Victoria County Hist. I, 365), which would seem to support the derivation from shire-wood, "the wood belonging to, or forming part of, the county."

But this is not wholly satisfactory either. I venture to suggest that the word scir - is used here in the same sense as in Shireoaks (q.v.), and Shire Dyke, a little stream forming part of the boundary between the counties of Nottingham and Lincoln. Its meaning is "boundary, division." Jellinghaus (p. 3I6) connects the word with modern Westphalian Schier ${ }^{2}$, of the same meaning, which enters into numerous Low German field names, such as Schiereneiken, "Shire-oaks," Schierenböken, "-beeches," Schierholz, "-holt, or wood." This last name is repeated in the O.E. scirholt quoted from a charter in Jellinghaus' article ${ }^{3}$. There exists also a Shirland in Derbyshire, which goes back to older Scirlund (Inq. P.M. 56 He. III), lund being the Scandinavian word for "wood." It may be noted here that O.E. scīr-, " boundary," is not connected with O.E. scieran, sceran, "to cut, shear"; Prof. Skeat in his Etymological Dictionary (I9IO, s.v. shire) remarks that its root is unknown.

If this explanation is adopted, the meaning would be "boundary forest." This seems a most appropriate name, seeing that Sherwood Forest stretches along the boundary between Nottinghamshire and Derbyshire, and that part of its ancient bounds, as laid down in the perambulations, actually coincides with the modern line dividing the two counties. Moreover, we learn from Tacitus (Germania, XL, I; Annales, I, 6I) that dense, impenetrable forests were looked upon as the safest boundaries

1 See Gertrud Stockmeyer, Das Naturgefühl in Deutschland im ro. u. Ir. Jahrhundert. Leipzig u. Berlin, rgro, p. 8.

2 O. Saxon $\bar{\imath}$ remains unchanged in Low German; see Herm. Teuchert, Laut und Flexionslehre der Neumärkischen Mundart, $\$$ 55, Zeitschr. f. deutsche Mundarten, 1907-8.

${ }^{3} \mathrm{Cp}$. also the expression andlang scire on hweðels heal, Cod. Dipl. 5, 358, 15. 
by the Germans. Sherwood Forest certainly was of that character. Boundaries separating peoples and tribes so frequently coincided with forests that primitive Germanic *markō-, Gothic marka, "boundary," actually changed its.meaning in the Scandinavian languages, which use the word mark in the sense of "wood." In the O.H.G. fragment of a geographical didactic poem known as "Merigarto," a passage is found illustrating this function of large tracts of wood-covered land, which I cannot refrain from quoting. It runs as follows :

"michili perga skinun duo an der erda.

die sint vilo hôh, habant manigin dichin lôh.

daz mag man wunteren daz dâr ie ieman durh chuam.

dâmit sint dei rîche giteilit ungelîhe."

The phonetic development offers no difficulties. The vowel $\bar{\imath}$ was shortened before the combination $r w$; later on, ir and $e r$ were levelled under one sound, a change which is reflected in the modern spelling. For a similar development $\mathrm{cp}$. sheriff, from O.E. scìr-gerēfa.

ShIREOAKs (Shireaks, Hope).

I 2 16-1 $307\left\{\begin{array}{l}\text { Scirop } \\ \text { Chirbrok }\end{array}\right\}$ Testa de N.

I 272-1 307 Shiroaks, Index.

1458 Schyroks, Bodl. Ch. and R.

I 535 Sirokks, Valor Eccles.

1637 The Shireokes, Map in Camden.

The name in Camden's Map does not seem to apply to a village but rather to a district. The "Shire Oaks" probably were a number of trees or a small copse near the boundary of the county. Legend speaks of one tree only as having given its name to the locality ${ }^{2}$. All the spellings, however, are in the plural. John Evelyn in "Sylva" (1664) has an interesting note on this supposed tree which, however, he knew by hearsay only. He writes: "Shireoak is a tree...which drops into 3 shires, viz. York, Nottingham and Derby."

1 "Large mountains appear there on the earth. These are very high, they have many a dense forest. One may well wonder that man ever penetrated them. By these the kingdoms are divided unequally."

2 See J. Stacye in White's "Dukery Records," pp. 70 sqq. 
The pl. n. Skyrack in Yorks. has a similar meaning, but is entirely Scandinavian in form, as appears still more clearly in the D.B. spelling which is Schyrayk.

The above spellings of Testa de N. are blunders due to false analogy.

SibTHORPE.

I086 Sibetorp, D.B.

I 199-1 2 16 Sibbetorp, Index.

c. I 200 Sibetorp, Woll. MSS.

I 302 Sibbthorp, F.A.

"The habitation or village of Sibba or Sibbi." The pers. n. may be of O.E. or Scandinavian origin. The nature of the second element speaks in favour of the second alternative. Sibbi is, however, not mentioned by Dr Björkman as a Norse name found in England.

SKEGBY.

$$
\begin{aligned}
& \text { I086 }\left\{\begin{array}{l}
\text { Schegebi } \\
\text { Schachebi }
\end{array}\right\} \text { D.B. } \\
& \left.\begin{array}{l}
1302 \\
1316
\end{array}\right\} \text { Skegby, F.A. }
\end{aligned}
$$

"The $b \bar{y}(r)$ or dwelling of Skeggi." The pers. n. as well as the second element is of Norse origin. The meaning of the former is "the bearded one."

SmITE (river).

$$
\text { I 535-43 }\left\{\begin{array}{c}
\text { (a praty Broke or Ryveret } \\
\text { caullit) Myte }
\end{array}\right\} \text { Leland, I, I06. }
$$

c. I6r 3 Snite, Drayton's Polyolbion, 26, 32.

I637 Snite, Map in Camden.

In O.E. we find the word smitta, "a foul, miry place." See Cod. Dipl. III, I66; 2-20; V, I05; I3-36. This is connected with O.E. smittan, "to daub, smear, pollute." If this word or some other derived from the same root is contained in the above name, the sense would be "dirty, miry water, or stream."

The omission of initial $s$ in Leland's form is remarkable. Can he have copied it from a Norman-French docurnent? Cp. the loss of $s$ in Nottingham. The change of $m$ to $n$ after $s$ is due to assimilation. 
SNEINTON [snentn].

\section{Type $I$.}

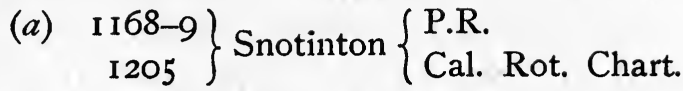

(b) 1215 Snoditon, Cal. Rot. Chart.

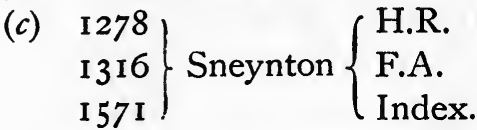

\section{Type II.}

I086 Notintone, D.B.

O.E. Snotinga tün, "the homestead of the Snotings." The same family that settled at Nottingham (q.v.) seems to have founded a village here. Type II represents the Norman pronunciation with the initial $s$ dropped as in Nottingham. As, however, the Norman element was not so overwhelmingly strong in this place as in the neighbouring fortified town, the native form prevailed.

The phonetic development of this name presents several interesting features. $n g[\eta]$ became assimilated to the following $t$; the first $t$ apparently was voiced under the influence of the surrounding vowels (Type I $b$ ). After that change it disappeared, so that the vowels of the first and second syllables, $o$ and $i$, collided and formed a diphthong. The diphthong oi being unfamiliar to the English-speaking population-M.E. $o i$ is of French origin-it was soon replaced by $e i$ which occurred in their language as the descendant of O.E. eg, eg, and Scandinavian $e i$. This diphthong which is preserved in the modern spelling was monophthongised to $\bar{e}$ probably in the I 5 th century (Horn, §II4). This latter sound was shortened before the combination $n t$ in pronunciation, the result being [e] as in says [sez], said [sed] etc.

The Norman form of D.B. seems to have been preserved in the name of Notintone Place in Sneinton.

SOAR (river).

I253 Sor, Cal. Rot. Chart.

This may be a Celtic river-name; $\mathrm{Mr}$ McClure (p. 264, note 2) proposes to connect it with the Sarua of the Ravenna 
Geographer. A name Sordic (-ditch) is mentioned in the index of Kemble's Cod. Dipl., and there exists a Sorbrook in Oxfordshire. On the continent, one finds several river-names compounded with Sor-, as O.H.G. Soraha, Sorna (Förstemann, II).

Southwell [saðə] (Suthull, Hope).

$$
\text { Type } I \text {. }
$$

958 at Suðwellan, Cart. Sax. I029.

I086 Sudwelle, D.B.

$\left.\begin{array}{ll}\text { II } 30 & \text { Sudwell } \\ \text { I33 I } & \text { Suthewell }\end{array}\right\}$ Index.

I637 $\left\{\begin{array}{l}\text { Southwell } \\ \text { Suthwell }\end{array}\right\}$ Camden, p. 549, and Map.

\section{Type II.}

$\left.\begin{array}{l}\text { I278 } \\ \text { I29I } \\ \text { I323 }\end{array}\right\}$ Suwell $\left\{\begin{array}{l}\text { H. R. } \\ \text { Tax. Eccles. } \\ \text { Bor. Rec. }\end{array}\right.$

The etymology is obvious. "The modern name of the town is supposed to have arisen from a spring or well on the south side of the church; now called Lady Well and Holy Well, a noted spring situated on the right of the cloisters" (White, Directory, I 853 , p. 509). It is equally, if not more probable that the name was given in contradistinction to Norwell, "the north well," some seven or eight miles to the north-east ${ }^{1}$. The shortening of the vowel (O.E. $\bar{u}$ in $s \bar{u} \bar{d})$ ), the loss of initial $w$ and final $l$ are explained elsewhere (Phonology, $§$ I ; I8; 2I). Type II, which has not survived, is an interesting example of the loss of $t h[\mathrm{k}]$ before $w$, which is also encountered in the modern pronunciation of southwester [sauwesta] (Horn, § 20I).

SowlKholme or SoOKholme [sakm].

I 89 Sulcholm, P.R.

I272-I 307 Sulholm, Inq. P.M. II.

c. 1500 Solcome, Inq. P.M. c. I 500.

I 553 Suckholm, Index.

I637 Sowcam, Map in Camden.

1 " The church of Southwell had possessed a manor at Norwell before the Norman Conquest" (Victoria County Hist. II, 153). 
O.E. sulh cumb, " miry, wet valley." Cp. sulig cumb, Cart. Sax. 589. The second element, O.E. cumb, "a deep, hollow valley," was originally borrowed from some Celtic language. The first part, which does not seem to occur independently in O.E. literature, is identical with O.H.G sulag, "miry pool, volutabrum," found by Förstemann (II) in numerous pl. ns. such as Solach near Tegernsee from O.H.G. Suligiloch ${ }^{1}$.

The spellings in -holm are due to confusion with the pl. n. element holme. Camden's form shows that, after the loss of the $h$, the $l$ had become vocalised ; ow stands for M.E. $\bar{u}(<u+u(l))$; this $\bar{u}$ was shortened as in the Index spelling of 1553 and the modern pronunciation. This interpretation of the pl. $n$. is borne out by a description of the locality. "A quarter of a mile S.W. of the village, is an excellent spring of water, where formerly was a bath; from it a small stream runs through the village, and joins the Meden from Pleasley" (White, Directory, I853, p. 653).

SPALFORD.

\section{I086 Spaldesforde, D.B. I302 Spaldeford, F.A.}

If the first element is a pers. $n$. as seems to be indicated by the presence of the genitival $s$, it would be an O.E. Spald(a), which is not recorded in the Onomasticon, but assumed to have existed by Prof. Skeat on the evidence of its occurrence in pl. ns. (Pl. Ns. of Huntingdon, p. 352). The meaning would be "Spalda's ford." This pers. name might be identical with the early Germanic Spatalus quoted by Werle (p. 54), which looks like a diminutive in -al derived from the ancestor of O.H.G. Spatto (Förstemann). $t l$ becomes $l d$ in certain O.E. dialects (cp. botl-bold, Sievers, $§ 196,2)$.

There is another possibility. The $s$ in D.B. may very well be spurious, cases of the insertion of an inorganic $s$ by the compilers of that survey being very numerous (Zachrisson,

1 In their edition of the Crawford Charters, Messrs Napier and Stevenson (p. 47) explain Sulhford as " a ford approached on one or both sides by a sunk road or gully." I do not agree with their interpretation, but prefer to connect this name too with the O.H.G. word (see also Jellinghaus, p. 3 I 7 ). 
pp. I I 8 sqq.) If that is so, the first element might represent O.E. spätl, spāld, which two forms stand in the same relation as botl, bold quoted above. spāld means "saliva," but as there exists a verb spātlan, "to spit foam," we may infer that späld could be used in the sense of "foam" as well. The name "foam(y) ford" seems a very natural one.

The shortening of the vowel $\bar{a}$ and the loss of $d$ are the results of natural tendencies (Phonology, $\$$ I ; I2).

STANFORD-ON-SOAR.

$$
\left.\begin{array}{l}
\text { 1086 } 302
\end{array}\right\} \text { Stanford }\left\{\begin{array}{l}
\text { D.B. } \\
\text { F.A. }
\end{array}\right.
$$

"The stone ford," O.E. stān ford. The name applies either to the condition of the river-bed, or to stepping-stones, by means of which the ford was crossed. There are fifteen Stanfords, Stamfords or Stainforths in England, the last-named being Scandinavian in both elements. Isaac Taylor (Engl. Village Names, $\S 5$ ) says that they were so named because they were "paved with stones." The name Steinfurt is found in Germany.

O.E. $\bar{a}$ was shortened before the combination $n f$ previous to becoming rounded in early M.E. (Phonology, $§$ I $a$ )

STANTON-ON-THE-WOLDS.

$$
\begin{aligned}
& \text { I086 Stantun, D.B. } \\
& \text { I } 89 \text { S Stanton }\left\{\begin{array}{l}
\text { P.R. } \\
\text { Bor. Rec. } \\
\text { I } 222
\end{array}\right\} \text { } \\
& \text { I222 Estanton } \\
& \text { I240 Stanton-super-Wold }\} \text { Bor. Rec. } \\
& \text { I637 Stannton, Map in Camden. }
\end{aligned}
$$

O.E. stan tün, "the scony homestead, the village on the stony land." The country round about Stanton is extremely bleak, and the land " of a sandy wet quality" (White, Directory, I 853 , p. 404).

For the development of O.E. $\bar{a}$ see Stanford. Estanton is a Norman-French form, with $e$ prefixed to the initial combination $s t$ in conformity with a general tendency prevalent among French speakers (Zachrisson, pp. 55 sq.). 
STAPLEFORD [stæplfəd].

$$
\begin{aligned}
& \text { I086 Stapleford, D.B. } \\
& \left.\begin{array}{l}
\text { I254 } \\
\text { I } 284
\end{array}\right\} \text { Stapilford }\left\{\begin{array}{l}
\text { Index. } \\
\text { F.A. }
\end{array}\right. \\
& \left.\begin{array}{l}
\text { I } 348 \\
\text { I356 }
\end{array}\right\} \text { Stapulford, Index. }
\end{aligned}
$$

"The ford by or leading to the pillar." The name is derived from the stone cross which still stands near the church, and has been declared to go back to Anglo-Saxon times to a date not later than the ninth century (Guilford, p. I87). O.E. stapol means "a pillar, boundary mark." In old German law, the word stapol had a special sense : it denoted the pillar near which the courts assembled and where judgment was given. This signification may also have been possessed by the stapol from which this pl. $\mathrm{n}$. is derived (see Grimm, Rechtsaltertümer, p. 804). Förstemann (II, s.v. Stapf) quotes the following passage: "ad regis staplum, vel ad eum locum, ubi mallus est." Ducange (Gloss. Mediae et Infimae Latinitatis) explains "mallus" as meaning "Publicus conventus, in quo majores causae disceptabantur, judiciaque majoris momenti exercebantur a Comitibus, Missis dominicis, aliisque Judicibus."

Prof. Skeat denies that the word stapol could be applied to a stone pillar. He says: "A.S. stapol simply means a wooden post or pole; and Staple-ford merely means that such a post marked the position of the ford. Where is the evidence that it ever meant a sculptured pillar? I take it to be all a fantastic dream..." (Notes and Queries, II, S. II, I9IO).

Prof. Skeat's view is supported by the fact that there exist many other Staplefords in other counties where there are no stone crosses. Both interpretations may be right, so that, until further evidence is adduced, the reader must choose between the two possibilities as the fancy takes him.

Staunton.

$$
\text { Type } I \text {. }
$$

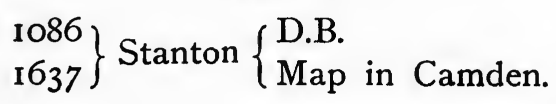

M. 


\section{Type II.}

$$
\left.\begin{array}{c}
\text { I216-I307 } \\
\text { I302 }
\end{array}\right\} \text { Staunton }\left\{\begin{array}{l}
\text { Testa de N. } \\
\text { F.A. }
\end{array}\right.
$$

This name is identical in origin and meaning with Stanton, above. Type II, which persists in the current modern form, represents the Norman-French pronunciation of this name, with aun for an (see Saundby).

STAYTHORPE.

$$
\text { Type } I \text {. }
$$

c. I 175 Stiresthorp, Woll. MSS.

$$
\text { Type II. }
$$

(a) 1086 Startorp, D.B.

$\left.\begin{array}{l}\text { I } 278 \\ \text { I } 302\end{array}\right\}$ Starthorp $\left\{\begin{array}{l}\text { H.R. } \\ \text { F.A. }\end{array}\right.$

$\left.\begin{array}{l}\text { I } 302 \\ \text { I } 346\end{array}\right\}$ Sternethorp

1346 Starthorp $\}$ F.A.

I4I 2 Sternethorp, Index.

c. $I 500\left\{\begin{array}{l}\text { Sterthorp } \\ \text { Starethorp }\end{array}\right\}$ Inq. P.M. c. 1500 .

I 535 Stertherop, Valor Eccles.

(b). c. I 500 Stathorpe, Inq. P.M. c. 1500.

"The habitation or village of Styr." This Scandinavian pers. $n$. is most faithfully preserved in Type $I$; it is a nick-name in origin, meaning "strife, battle." English forms of the same pers. n. are Ster, Sterre enumerated by Dr Björkman (p. 132). These latter have been substituted for the original Styr (Stir) in Type II. The $n$ which occurs in several spellings is the ending of the weak genitive. ar is regularly developed from ar; ar becomes $\bar{a}$ before open consonants (Type II $b$, Phonology, $\S 7$ ). The latter form survives in the modern spelling, ay standing for M.E. $\bar{a}$, now pronounced [ei].

\section{Stockwith (West).}

No early forms. For a discussion of the first element see the name below. The second theme may be either Scand. vað, "ford," or viðr, "tree, wood." Stocc wað might mean "the ford 
indicated by a "stock" or pole; compare Langreith, and Stapleford.

STOKE BARDOLPH.

$$
\begin{aligned}
& 1086 \text { Stoches, D.B. } \\
& 1302 \text { Stok, F.A. } \\
& \text { c. } 1500 \text { Stokkerdolffe, Inq. P.M. c. } 1500 .
\end{aligned}
$$

The original meaning of O.E. stocc is "stock, log, stump of a tree." Isaac Taylor (Engl. Village Names) says concerning the numerous places called Stoke that they derive their name from their position "near the stump of a tree in a half-cleared forest." Others believe that stocc was used to denote a "fenced-in place," i.e. an enclosure secured by means of "stocks" or wooden palings (Alexander, Pl. N. Oxfordshire, p. 196). It is also conjectured that stocc had the meaning not only of "log," but also of a collection of such, i.e. "a log-cabin" or "block-house." But why should the vowel in all the modern names be long, when the O.E. prototype contained a long or double consonant $c c$ ?

Bardolph is the name of a former owner added in order to distinguish the place from the other Stokes. The Inq. spelling records a curiously corrupted pronunciation.

STOKE (EAST).

$$
\begin{aligned}
& 1086\left\{\begin{array}{l}
\text { Stoches } \\
\text { Estoches }
\end{array}\right\} \text { D.B. } \\
& \left.\begin{array}{c}
\text { 1302 } \\
\text { 1273-1307 }
\end{array}\right\} \text { Stok }\left\{\begin{array}{l}
\text { F.A. } \\
\text { Index. }
\end{array}\right. \\
& \text { I } 586 \text { East Stoake, Index. }
\end{aligned}
$$

See preceding name. The initial $e$ of the second D.B. form is not a remnant of a prefixed distinctive east but owes its origin to a Norman-French habit of speech; cp. French esprit from Latin spiritus etc.

Stokeham.

$$
\begin{aligned}
& \text { I } 302 \text { Stocum, F.A. } \\
& \text { 1412 Stokum, Index. }
\end{aligned}
$$

O.E. et stoccum, "at the tree stumps," or, "at the log-cabins"?

The dative plural of O.E. stocc, of uncertain meaning. See Stoke Bardolph. 
STRAGgLETHORPE (under Cotgrave).

There are no early forms. Can the first element be a corruption of a Scandinavian pers. $\mathrm{n}$. *Strangulfr?

StRELLEy.

Type I.
I086 $\left\{\begin{array}{c}\text { Straleia } \\ \text { Straelie }\end{array}\right\}$ D.B.
I 166-7 $\left.\begin{array}{l}\text { Stratlega } \\ \text { I } 89 \text { Stradlega }\end{array}\right\}$ P.R.

Type II.

(a) I 89 Stretlee, Nottm. Ch.

$\left.\begin{array}{c}\text { I } 2 \text { 16-I } 307 \\ \text { I } 275\end{array}\right\}$ Stretleg $\left\{\begin{array}{l}\text { Testa de N. } \\ \text { F.A. }\end{array}\right.$

$\left.\begin{array}{l}\text { (b) I29I } \\ \text { I } 302 \\ \text { I } 428\end{array}\right\}$ Stredley $\left\{\begin{array}{l}\text { Tax. Eccles. } \\ \text { F.A. } \\ \text { F.A. }\end{array}\right.$

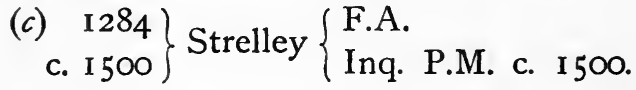

Type III.

c. I $500\left\{\begin{array}{l}\text { Stertley } \\ \text { Sterley }\end{array}\right\}$ Inq. P.M. c. I 500.

O.E. (Mercian) on strēt lèze, "in the field by the street." The O.E. (W. Sax.) strāt originally comes from the Latin strāta via and is usually employed of a Roman road. Such a one must have run past Strelley.

Type I comes from the W. Saxon variant of the O.E. word, $a$ being the result of the shortening of older $\overline{\boldsymbol{e}}$. The other types contain $e$ derived by the same process from the native Mercian $\bar{e}$. The development of the $t$ may be traced in its various stages through the early spellings. It is preserved intact in Type II $a$; then it becomes voiced under the influence of the surrounding sounds (Type II $b$ ), and is finally assimilated by the following $l$ (Type II $c$, Phonology, § I 3 ).

Type III, which perished, shows metathesis of $r$.

The pl. n. Streatley occurs in Bedfordshire. 
Sturton-In-the-Clay or Sturton-le-Steeple.

$$
\text { Type } I \text {. }
$$

I 166-7 Strotton, P.R.

c. I200 Strattone, Cal. Rot. Chart.

Type II.

I086 Estretone, D.B.

I 2 16-1 307 Strecton, Testa de N.

$\left.\begin{array}{r}\text { I } 278 \\ \text { I } 29 \text { I } \\ \text { c. } 1300 \\ \text { I } 302\end{array}\right\}$ Stretton $\left\{\begin{array}{l}\text { H.R. } \\ \text { Tax. Eccles. } \\ \text { Index. } \\ \text { F.A. }\end{array}\right.$

I 375 Neyerstretton

I 383 Ouerstretton

$\left.\begin{array}{ll}\text { I } 383 & \text { Ouerstretton } \\ \text { I } 384 & \text { Stretton en le Clay } \\ \text { I } 425 & \text { Stretton in the Clay }\end{array}\right\}$ Index.

c. 1500 Stretton, Inq. P.M. c. 1500.

\section{Type III.}

c. I 500 Stirton, Inq. P.M. c. I 500.

O.E. (Mercian) strēt tūn, "the homestead by the street." The Roman road to which the name refers is the one leading from Lincoln to Doncaster. Type $I$ is to be explained in the same way as Type I of Strelley (q.v.). The P.R. spelling of $o$ for $a$ is a scribal error; so is the $c$ which stands for $t$ in Testa de N. The initial $e$ of D.B. is Norman-French in origin. The $y$ in the Index form of $\mathrm{I} 375$ is a M.E. spelling for $b, t h ; u$ in the form of 1383 of course stands for $v$.

Type III which prevailed shows metathesis of $r$ (Phonology, $\S \mathrm{I} 5$ ). er, ir, ur all represent one and the same modern sound (Phonology, §8).

The distinctive addition-Norman-French en le Clay, English in the Clay-indicates the nature of the soil. Sturton is in the North Clay Division of Bassetlaw Hundred.

"Sturton-le-Steeple owes the latter part of its name to the far-seen array of twelve pinnacles with which the builders thought fit to surround the parapet" of the church tower (A. Hamilton Thompson, in "Memorials of Old Nottinghamshire," p. 52). 
STYRRUP Or STYRUP.

Type $I$.

I086 Estirape, D.B.

I 278 Stirap, H.R.

c. I 300 Styrap, Index.

$\left.\begin{array}{l}\text { I } 302 \\ \text { I } 348\end{array}\right\}$ Stirap $\left\{\begin{array}{l}\text { F.A. } \\ \text { Index. }\end{array}\right.$

Type II.

1414 Sterap, Index.

c. I 500 Sterop, Inq. P.M. c. I 500.

"The valley of Styr." This O.N. pers. n. has been discussed under Staythorpe (q.v.). An English variant of the same name, Ster, accounts for Type II. The second element represents O.E. *hop, which is found as an independent word in M.E. only, meaning "valley, hollow among hills."

The initial $e$ of D.B. is Norman-French in origin.

SutToN (near Granby).

I 79 Suttuna, Index.

1284 Sotton, F.A.

SUTTON-IN-ASHFIELD.

Io86 Sutone, D.B.

I316 $\left\{\begin{array}{l}\text { Sutton super Asshefeld } \\ \text { Sutton super Essefeld }\end{array}\right\}$ F.A.

I 535 Sutton super Lownde, Valor Eccles.

SutTon Bonington.

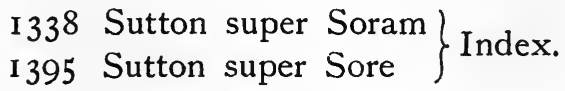

SUTTON-UPON-TRENT.

1412 Sutton, Index.

O.E. $s \bar{u} b$ tün, "the southern farmstead." It is, of course, impossible to say with regard to which place or object this name was originally given. It is one of the commonest pl. ns. in England.

The shortening of O.E. $\bar{u}$ before $t t$, the result of assimilation 
of $b$ by $t$, is a regular feature of sound-development (Phonology, $\$ 8$ I 13 ).

For the meaning of Ashfield see Kirkby-in-Ashfield. Lownde is from O.N. lundr, "wood" (see Lound). Bonington is the name of a separate parish (q.v.).

SYERSTON [saizstn].

Type $I$.

1086 Sirestune, D.B.

1302 Syreston, F.A.

c. I $500\left\{\begin{array}{l}\text { Syerston } \\ \text { Syreston }\end{array}\right\}$ Inq. P.M. c., I 500.

Type $I I$.

c. I 500 Syston, Inq. P.M. c. I 500.

O.E. Sigerīces tīn, "the farmstead of Sigerīi." This latter is an O.E. man's name of frequent occurrence.

O.E. $i g$ e becomes M.E. $i$, modern [ai] regularly. $\dot{c}$ is lost before $s$ in an unstressed syllable (cp. Ordsall).

Type II shows loss of $r$ before $s$ (Phonology, $§$ I 3 ).

Teversal.

\section{Type $I$.}

I086 Tevreshalt, D.B.

I227-77 Teversald, Non. Inq.

$\left.\begin{array}{ll}\text { I284 } & \text { Teversalt } \\ \text { I3 I6 } & \text { Turessalt }\end{array}\right\}$ F.A.

Type II.

I29I Tyv'salt, Tax. Eccles.

$\left.\begin{array}{ll}\text { I } 346 & \text { Tyrvesalt } \\ \text { I428 } & \text { Tyvershalt }\end{array}\right\}$ F.A.

The second element clearly stands for O.E. holt, "wood, copse." To this day the district can boast of an abundance of trees. In the unstressed syllable, $o$ is unrounded (cp. Egmanton) and final $t$-having first become $d$-is dropped.

There can be no doubt that the first element is a pers. $n$. Prof. Skeat assumes that there existed an O.E. man's name Tefer (Pl. Ns. of Cambs.), whose first syllable, however, must 
have contained a long vowel, or a diphthong, $\bar{e}$ or $\bar{e} o$, for only from one of these can both the $e$ and the $i$ of Types I and II respectively be derived. The pl. n. Tiverton found in Cheshire and Devon may contain the same pers. $n$. It is possible that an assumed Téfer represents the recorded O.E. peodfrib with the Norman initial $t$ for $b$. An O.H.G. Tiufher, in Tiufherreshusun (Förstemann), might be adduced here, although the initial consonants of the English and continental variants cannot easily be connected, unless we assume that $t$ represents the Upper German variant of O.H.G. $d$, from $b$.

THORESBY.

$$
\begin{aligned}
& \text { I086 Turesbi, D.B. } \\
& \text { I } 316 \text { Thuresby, F.A. }
\end{aligned}
$$

O.E. pores $b \bar{y}(r)$, "the dwelling of por." The latter pers. $n$. which is of Norse origin occurs frequently both as bor and, less often, bur.

THORNEY.

$$
\text { Type } I \text {. }
$$

I086 Torneshaie, D.B.

c. 1500 Thorney, Inq. P.M. c. 1500.

Type II.

c. 1216 Thornehawe, Index.

1227-77 Thornhawe, Non. Inq.

I291 Thornhauwe, Tax. Eccles.

$\left.\begin{array}{ll}\text { I302 } & \text { Thornagh } \\ \text { I } 316 & \text { Thorhawe }\end{array}\right\}$ F.A.

The two types differ in the form of the suffix: Type I contains O.E. hege, Type II O.E. haga, both meaning "hedge, enclosure." The name may, therefore, be translated by "thornhedge, or enclosure." The modern spelling shows influence of the more frequent suffix -ey from ege, "island." The $s$ of D.B. is due to false analogy: the clerk thought the first element was a pers. n. Similar cases of inorganic $s$ are frequently met with in Anglo-Norman records (Zachrisson, pp. I I 8, I I9). 
THOROTON.

$$
\begin{aligned}
& \text { I086 } \left.\begin{array}{l}
\text { Torvertune } \\
\text { Toruentun }
\end{array}\right\} \text { D.B. } \\
& \text { I } 242 \text { Thuruerton, Inq. P.M. I. } \\
& \text { I284 } \\
& \text { I } 363 \text { Thorverton, F.A. } \\
& \text { I637 Thoraton, Map in Camden. }
\end{aligned}
$$

"The tün or homestead of purfert." This Scandinavian pers. n. occurs in various forms in English sources, such as burfer $\delta$, porfr $\delta$, Toruerd etc. (Björkman, p. I55).

THORPE-IN-GLEBE.

$$
\left.\begin{array}{l}
\text { I086 Torp, D.B. } \\
\text { I } 302 \\
\text { I } 535
\end{array}\right\} \text { Thorp in Glebis }\left\{\begin{array}{l}
\text { F.A. } \\
\text { Valor Eccles. }
\end{array}\right.
$$

The original simple name of D.B. times meaning "the village" had soon to be provided with a distinctive addition. The Latin gleba, English glebe, is used in its wider sense, meaning "a piece of cultivated land, field," as it still does in poetic language.

THORPE-BY-NEWARK.

$$
\left.\begin{array}{l}
\text { IO86 } \\
\text { I I } 53
\end{array}\right\} \text { Torp }\left\{\begin{array}{l}
\text { D.B. } \\
\text { Index. }
\end{array}\right.
$$

See preceding name.

THRUMPTON.

I086 Turmodestun, D.B.

I 89 Turmodeston, Nottm. Ch.

c. I240 Thurmunston, Woll. MSS.

I244 Thurmodeston, Cal. Rot. Chart.

$\left.\begin{array}{ll}\text { I } 302 & \text { Thurmeton } \\ \text { I } 346 & \text { Thrumpton }\end{array}\right\}$ F.A.

"The tün or farmstead of burmod." This pers. n. represents Scandinavian pormötr on English territory. The spelling of the Woll. MSS. betrays influence of the pers. n. purmund. In the course of development, the entire second syllable disappeared 
with the exception of $m$ between which and the following $t$ a labial glide arose (Phonology, $\S \mathrm{I} 6$ ). Metathesis of $r$ is frequently encountered in the pl. ns. of this county, and may take place at any period (Phonology, $\S$ I 5 ).

THURGARTON.

$$
\begin{aligned}
& \text { I086 }\left\{\begin{array}{l}
\text { Turgarstune } \\
\text { Turgastune } \\
\text { Torgartone }
\end{array}\right\} \text { D.B. } \\
& \text { c. I I 70 } \\
& \text { I I } 89 \text { Turgartona, Woll. MSS. } \\
& \text { I } 278 \text { Thurgardton, P.R. } \\
& \text { I } 302 \text { Thurgerton, H.R. }
\end{aligned}
$$

"burgār's tün or farmstead." The pers. n. is the English form of the O.N. porgeirr, with $\bar{a}$ substituted for the cognate $e i$ (cp. Tollerton). It is remarkable that only the D.B. spellings contain a genitival $s$. The P.R. form may have been influenced by the feminine pers. n. purgerd, the English variety of the O.N. porgertr.

Tiln or Tyln, Tilne.

$$
\begin{aligned}
& \text { I086 }\left\{\begin{array}{l}
\text { Tilne } \\
\text { Tille }
\end{array}\right\} \text { D.B. } \\
& \text { I I } 89\left\{\begin{array}{l}
\text { Tilnea } \\
\text { Tilne }
\end{array}\right\} \text { P.R. } \\
& \text { I 227-77 Tylne, Non. Inq. } \\
& \text { I } 278 \text { Tilne, H.R. } \\
& \text { I } 293 \text { Tylne, Index. } \\
& \text { I } 535 \text { Tilneye, Valor Eccles. } \\
& \text { I } 599 \\
& \text { I637 Tilney }\left\{\begin{array}{l}
\text { Map. } \\
\text { Map in Camden. } \\
\text { Map. } \\
\text { I } 704
\end{array}\right\}
\end{aligned}
$$

O.E. et Tilan ège, "at Tila's island." This hamlet is situated on the eastern bank of the river Idle. The complete loss of the suffix is a remarkable feature (cp. Blyth, Idle).

Tila is an O.E. man's name. 
TOLLERTON.

$$
\text { Type } I \text {. }
$$

1086 Troclauestune, D.B.

I 166-7 Turlaueston, P.R.

\section{Type II.}

I294 Thorlaxton, Woll. MSS.

I 302 Torlaxton, F.A.

Types $I$ or $I I$ (continued).

$$
\begin{aligned}
& \left.\begin{array}{ll}
\mathbf{1} 284 & \text { Torlaston } \\
\mathbf{1 4 2 8} & \text { Toralston }
\end{array}\right\} \text { F.A. }
\end{aligned}
$$

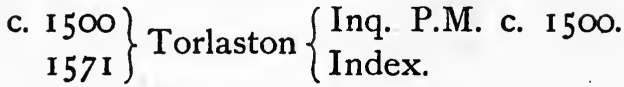

$$
\begin{aligned}
& \text { I } 578 \text { Thorlaston, Index. }
\end{aligned}
$$

$$
\text { Type III. }
$$

I539 Torlaton, Bor. Rec.

I 578 Torlarton, Index.

1637 Torloton, Map in Camden.

The second element is O.E. $t \bar{u} n$, "farmstead." Two different pers. ns. seem to be contained in Types I and II respectively: porläf and burlac. The former is an anglicised variety of O.N. porleifr, whereas the latter stands for O.N. porleikr. O.E. $\bar{a}$ is frequently substituted for O.N. ei, see Björkman, p. 203 ; cp. Thurgarton. The pers. n. contained in Type I seems to be the original one, for which that of Type II was substituted. The forms arranged in the third section may have descended from either type, as $k$ often disappears before $s$, and $v$ is lost before a consonant.

Type III is the ancestor of the modern form. It is not probable that the $r$ in the unstressed syllable represents the ending of the O.N. nominatives borleifr or borleikr. It is more likely that after the loss of $s, r$ and $l$ changed places, $r l$ becoming $\operatorname{lr}$ (Phonology, $\S$ I5). The Index spelling of 1578 proves that the relative position of the two liquids was unsettled.

The D.B. spelling shows metathesis of $r$ which is frequently found in that document (Stolze, §29). I cannot explain the $c$ satisfactorily. 
The transition from initial $b$ to $t$ took place under NormanFrench influence. See Zachrisson, pp. 39 sqq., cp. Teversal and Torworth.

TORWORTH [torib].

$$
\begin{aligned}
& \text { I086 Turdenworde, D.B. } \\
& \text { I278 Thorchewurh, H.R. } \\
& \text { I3 } 6 \text { Tordworthe, F.A. } \\
& \text { I704 Tarworth, Map. }
\end{aligned}
$$

"The veorb or habitation of pore $\delta$, or pureð." This pers. $\mathrm{n}$. goes back to O.N. porrøbr and is discussed at length by Dr Björkman (pp. I48 sqq.). $c h$ and $h$ in the H.R. seem to stand for $\delta$ and $b$ respectively. The spirant $b$ was occasionally mistaken for $h$ by Norman scribes, but it would be difficult to explain why $c h$ which usually denotes the sound of $k$ before front vowels should represent $\partial$ in the H.R. spelling.

The loss of $\delta$ between $r$ and $w$ is natural. Initial $b$ was turned into $t$ under Norman influence. See preceding name.

TOTON.

$$
\text { Type } I \text {. }
$$

I086 Tolvestune, D.B.

$$
\text { Type II. }
$$

I 89 Turuerton, P.R.

$$
\text { Type III. }
$$

(a) 1086 Tovetune, D.B. $\left.\begin{array}{l}1284 \\ 13 \text { I } 4\end{array}\right\}$ Toueton $\left\{\begin{array}{l}\text { F.A. } \\ \text { Index. }\end{array}\right.$

I 346 Touiton, F.A. 1480 Towton, Woll. MSS.

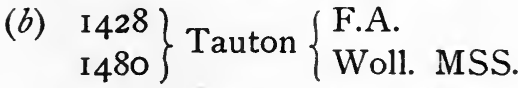

c. I 500 Tawton, Inq. P.M. c. 1500 .

"The tīn or farmstead of borolf." This pers. n. represents O.N. pōrolfr, and is found in an abbreviated form as $b o l f(r)$ both on Scandinavian and English territory. The latter variant constitutes the first element of Type I, from which Type III is derived. In Type II, the pers. n. purfert seems to have been substituted for the original one. 
The phonetic development is as follows: $l$ became vocalised and the $v$ soon disappeared after the diphthong ou. In the I 5 th century, M.E. ou and au seem to have become levelled under one sound, that of M.E. $\bar{j}$ (Phonology, $\S 9$ ). This explains Types III $a$ and III $b$, and also the modern spelling.

TRENT.

Trisantona, in Roman times.

Treanta, Bede, Hist. Eccles.

923 Treonta, A.S. Chron.

I 278 Trent, Trenth, H.R.

A name of British origin, of which the meaning cannot be ascertained. See Bradley, Essays and Studies, I, p. 24; Miller, Pl. Ns. in the O.E. Bede, p. 52. Among early antiquarians the belief existed that this name was connected with Latin triginta, French trente, "thirty." This theory is set forth by Drayton in his "Polyolbion"; the passage deserves to be quoted. The poet represents the river as explaining its own name:

"In her peculiar praise, lo thus the River sings:

What should I care at all, from what my name I take,

That Thirty doth import, that thirty rivers make,

My greatness what it is, or thirty abbeys great,

That on my fruitful banks, times formerly did seat:

Or thirty kinds of fish, that in my streams do live,

To me this name of Trent did from that number give.

What reck I..." (26, I 86 sqq.).

Milton alludes to the same interpretation in one of his earliest productions, when he sings:

"Of Trent, who like some earth-born giant spreads

His thirty arms along the indented meads."

(At a Vacation Exercise, 1627.)

TRESWELL or TIRESWELL.

Type I.

I086 Tireswelle, D.B.

1272-1307 Tyrswell, Index.

$\left.\begin{array}{l}\text { I } 278 \\ \text { I } 302\end{array}\right\}$ Tyreswell $\left\{\begin{array}{l}\text { H.R. } \\ \text { F.A. }\end{array}\right.$ 


\section{Type II.}

I428 Tressewell, F.A.

$\left.\begin{array}{l}\text { I } 535 \\ \text { I637 }\end{array}\right\}$ Truswell $\left\{\begin{array}{l}\text { Valor Eccles. } \\ \text { Map in Camden. }\end{array}\right.$

I704 Triswell, Map.

The meaning of the termination is clear: O.E. zviell, "fountain, spring." The first element is apparently a pers. n. It may represent an O.E. ${ }^{*} T i r$, short for a full name composed with that element such as Tirweald, Tirzulf. There exists also an O.N. man's name byri of which traces are found in English sources (Björkman, p. I64). Initial $t$ for $b$ would be due to Norman-French influence (see Tollerton). Type II arose out of Type I through metathesis of $r$ (Phonology, $\S$ I5). The discrepancy of vowels in Type II is not easily accounted for; the $r$ may have had some influence.

Both types survive in the alternative modern spellings.

\section{TROWELL.}

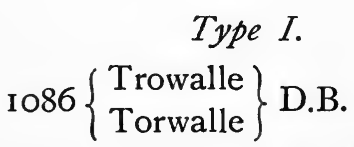

c. I 200 Trowall, Woll. MSS.

\section{Type II.}

c. II75 Trowella, Woll. MSS.

1227-77 Trouwell, Non. Inq.

I 302 Trouell, F.A.

1637 Trowell, Map in Camden.

Type III.

I284 Treweil, F.A.

This is a difficult name to explain. I believe that the first element throughout the three types is O.E. trēow, "a tree, a forest ; wood." The O.E. form of this word is most faithfully preserved in Type III, probably under the influence of the independent word, M.E. tree. In the other types, it has undergone certain changes caused by a shifting of accent in the triphthong eou, which latter arose out of the vocalisation of $w$ in 


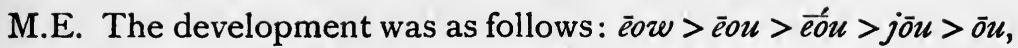
with loss of the glide $j$ after $r$. It is impossible to say what the exact pronunciation of the combination ou, ow in the M.E. forms was. According to Camden's spelling, the contemporary pronunciation of the diphthong seems to have been the same as that of M.E. ou, au, $\bar{q}$, all three of which coincided in sound, as was shown under Toton (q.v.). If, however, the modern pronunciation [trauəl] is genuine, ow would stand for M.E. $\bar{u}(<\bar{o} u$ ?).

The suffix is ambiguous, admitting of different interpretations. Type I, which seems to be the original, contains either O.E. weall, "a wall, rampart," or Scandinavian vollr, "a field, open country," in a more primitive form (<*al\$uz). For this ending the more usual well was substituted. If the former interpretation is accepted, the meaning of the pl.n. would be: "(at) the rampart made of wood, the palisade"; if the latter, one might translate by "the plain covered with trees."

It is unlikely that the second element was O.E. weald, "forest," although the early spellings do not preclude this, final $d$ disappearing at a very early date after $l$. I cannot see what sense there would be in forming a tautology like trēo weald, "tree forest."

TUXFORD.

\section{Type $I$.}

I086 Tuxfarne, D.B.

1272-1 307 Tuxforne, Inq. P.M. II.

Type II.

I 258 Tuggesford, Inq. P.M. I.

1327-77 Tuxford, Non. Inq.

$\left.\begin{array}{l}\text { I } 278 \\ \text { I } 36\end{array}\right\}$ Tukesford $\left\{\begin{array}{l}\text { H.R. } \\ \text { F.A. }\end{array}\right.$

I 535 Tuxforde, Valor Eccles.

"The ford of Tucca or Tuki." The latter of these pers. ns. is of O.N. origin (Björkman, p. 142), the former is found in early Anglo-Saxon charters. Which of the two is implied in this case, it is impossible to say. The fact that the genitive ends in es and not in an might speak in favour of the Scandinavian 
name: yet examples of originally weak pers. ns. forming a strong genitive are by no means rare; see Annesley.

No importance is to be attached to the curious spelling, $g g$ for $k$, of $\mathbf{1} 258$.

I cannot explain the substitution of $n$ for $d$ in the suffix of Type I, unless it is due to a scribal error.

Тутнву [tiðbi].

$$
\begin{array}{ll}
\text { I086 } & \text { Tiedebi, D.B. } \\
\text { c. I } 190 & \text { Titheby, Woll. MSS. } \\
\text { I428 } & \text { Tythby, F.A. } \\
\text { I } 535 & \text { Teythby, Valor Eccles. }
\end{array}
$$

The suffix is the well-known Scandinavian $b \bar{y}(r)$, "dwelling." The first element may be a pers. n., but I am unable to suggest what its exact form and derivation were. The spelling $i e$ in D.B. is remarkable and seems to imply that the vowel intended to be represented was M.E. $\bar{e}$, whatever its source; see Stolze, p. 9.

UPTON.

$$
\text { I086 }\left\{\begin{array}{l}
\text { Upetun } \\
\text { Opeton }
\end{array}\right\} \text { D.B. }
$$

This village is said to be situated "on a gentle acclivity" (White, Directory, 1853, p. 520). See following name.

Upton (in Headon Parish).

$$
\begin{aligned}
& \text { I086 Upetone, D.B. } \\
& \text { I } 278 \text { Upton, H.R. } \\
& \text { c. I } 500 \text { Upthorp, Inq. P.M. c. I } 500 .
\end{aligned}
$$

"The tün or farmstead on high ground." This second Upton occupies the highest part of the surrounding country. The prefix $\bar{u} p$ is used in O.E. to denote a high situation, as in $\bar{u} p$ $h \bar{u} s$, "upper chamber," upp flōr, "upper floor," etc. It is also encountered in numerous pl.ns. other than Upton, as in Upminster, Uproood. The same element has a similar meaning in the Low German pl. ns. Uphausen, Upstede etc., Jellinghaus, p. 325.

The substitution of -thorp for -ton does not call for an explanation. 
WALESBY.

$$
\begin{aligned}
& \left.\begin{array}{l}
\text { 1086 } \\
\text { I } 204
\end{array}\right\} \text { Walesbi }\left\{\begin{array}{l}
\text { D.B. } \\
\text { Index. }
\end{array}\right. \\
& \text { I316 Walesby, F.A. }
\end{aligned}
$$

"The $b \bar{y}(r)$ or dwelling of Wealh, or the Briton, or the slave, serf." The original meaning of O.E. wealh is "foreigner, Briton, Welshman"; after the subjection of the Britons, the word assumed the sense of "slave, serf." It also occurs as a pers. n. In which of these three senses the word is used in the above pl. n. it is impossible to say.

WALKERINGHAM.

$$
\begin{aligned}
& \begin{array}{l}
\text { 1086 Wacheringeham, D.B. } \\
\text { c. 1216 Walcringham }
\end{array} \\
& \text { 1272-1307 }\left\{\begin{array}{l}
\text { Waucringham } \\
\text { Walcringham }
\end{array}\right\} \text { Index. } \\
& \text { 1278 }\left\{\begin{array}{l}
\text { Waleringham } \\
\text { Waveringham } \\
\text { Walcringham }
\end{array}\right\} \text { H.R. } \\
& \text { 1291 Waltryngham, Tax. Eccles. } \\
& \text { I316 Walcringham, F.A. } \\
& \text { 1637 Walkingham, Map in Camden }
\end{aligned}
$$

"The home of the descendants of Walchere," O.E. Wealhheringa hām. The O.E. pers. n. Wealhere frequently appears as Walchere $(c h=[\mathrm{k}])$. This same patronymic is probably contained in the Yorks. pl. n. Walkingham (P1. Ns. of the W. Rid.).

The early forms exhibit a considerable variety of spellings which are, however, of but small importance. au for al shows Norman vocalisation of $l$ (cp. Mansfield; Zachrisson, pp. I46 sqq.). $t$ for $c=k$ is a scribal mistake frequently met with in mediæval documents.

WALLINGWELLS.

\section{Type $I$.}

I 278 Wellandwell, H.R.

I289 Wallendewelles, Inq. P.M. II.

I29 I Wallandwells, Tax. Eccles.

I300 Wallandewelles, Index. 


\section{Type II.}

I5 16 Wallingwells, Bodl. Ch. and R.

1637 Woldingwells, Map in Camden.

O.E. weallende welles, "the boiling, i.e. bubbling and flowing springs." This is the site of a former nunnery which is described by the pious founder as " [unus locus] in meo parcho de Carletuna juxta fontes et rivum fontium "- by the wells and the stream of the wells (Dugdale, Monast. Angl., new ed. IV, 295, temp. reg. Steph.).

The first part of this name is a regular O.E. present participle. The change from en to ing took place at a comparatively late date; cp. Types I and II. I am not prepared to say whether this transition is due to a special sound-law (Phonology, $\S \mathrm{I} 3$ ) or to analogy of the verbal nouns which always ended in -ing as assumed by Dr Sweet, N. Engl. Gramm. § I 239.

We find a corresponding O.H.G. name in Wallendenbrunno, "at the flowing well or spring" (Förstemann, II), modern Walbernbrunnen, Odenwald.

WARSOP.

$$
\text { I086 }\left\{\begin{array}{l}
\text { Wareshope } \\
\text { Waresope } \\
\text { Warsope }
\end{array}\right\} \text { D.B. }
$$

1272-1307 Warsop alias Warshope, Inq. P.M. I. 1302 Warsop, F.A.

O.E. Wares hop, "the valley of Ware." The latter male name is recorded but once in the Onomasticon. It may have been more frequent as a short form of a name composed with War-, such as Warbeorht, Warmund etc. A similar name is contained in the Low German pl. ns. Warenrode, Warantharpa, modern Wahrendorf near Münster (Förstemann, I).

\section{WatNaLL [wotnə] (Watnall Chaworth and Watnall Cantelupe).}

\section{Type I.}

I086 Watenot, D.B. 


\section{Type II.}

c. I200 Wattenhou, Woll. MSS.

1216-1307 Watenhow, Testa de N.

I278 Watenhou, H.R.

I 302

1316 Watenowe, F.A.

1346

I 506 Watnowe, Bor. Rec.

1535 Whatnaw, Valor Eccles.

\section{Type III.}

c. 1700 Watnall, Map in Camden (ed. 1722).

"The hill of Wata," O.E. Watan höh. The final $t$ in the D.B. spelling is an error for $c$, which stands for $h$ (cp. Wysall; see Zachrisson, Latin Influence, p. 22). Type I contains the suffix in the nominative, whereas Type II goes back to the dative at Watan $h \bar{o} z$. The diphthong ow from $\bar{o}_{3}$ must have become the same in pronunciation as M.E. au with which it was confused by the compiler of Valor Eccles. This au or aw in many cases stood for older-al, from -healh, -hale, and it was for that reason that the suffix came to be written -all, as in Type III and the modern spelling, although the $l$ was never pronounced, except by those who rely on the spelling only.

The element $h \bar{o} h$ is treated at length by Prof. Wyld in Pl. Ns. of Lancs. p. $35 \mathrm{I}$. Its meaning in O.E. is "heel, hill, promontory." Watnall is situated on an eminence from which it apparently derives its name.

Cantelupe and Chaworth are the names of former owners belonging to the Norman nobility.

WELBECK (Abbey).

c. I 89 Wellebec, Nottm. Ch.

1278 Wellebeck, H.R.

I $284\left\{\begin{array}{l}\text { Welbek } \\ \text { Welbecke }\end{array}\right\}$ F.A.

The suffix is the Scandinavian $b e k k(r)$, "a brook." The first element apparently stands for O.E. wiell, well, "stream, spring." 
The meaning of the compound seems to be "the brook flowing from the spring."

WELHAM.

$$
\begin{aligned}
& \text { ro86 }\left\{\begin{array}{l}
\text { Wellun } \\
\text { Wellon }
\end{array}\right\} \text { D.B. } \\
& \text { 1276 Wellum, Index. } \\
& \text { 1316 Wellom, F.A. } \\
& \text { I457 Wellum, Index. }
\end{aligned}
$$

O.E. at wellum, "at the wells, or waters." See preceding name, and cp. Kelham. The name is explained by White (Directory, I853, p. 693) as follows: "Its name is derived from St John's well, which was long famed for its medicinal virtues in scorbutic and rheumatic complaints; it is now a commodious bath, though it has lost much of its former celebrity."

\section{WELLOW.}

$$
\begin{aligned}
& \text { I278 } \left.\begin{array}{l}
\text { Welhagh } \\
\text { Welhah }
\end{array}\right\} \text { H.R. } \\
& \text { I } 302 \text { Welhawe, F.A. } \\
& \text { I } 535 \text { Wellaw, Map in Camden. } \\
& \text { I704 Welley, Map. }
\end{aligned}
$$

The suffix stands for O.E. haga, "a hedge, fence; hence a piece of ground enclosed or fenced in, an enclosure." A word of similar meaning is O.E. hege which may be contained in the spelling of $\mathrm{I} 704$, although it is more likely that $-e y$ represents the more usual termination, O.E. eg e, introduced by the engraver.

The first element looks like O.E. wiell, well, "a spring, stream." However, I cannot say what is the exact meaning of the compound.

For the spelling ow instead of M.E. aw see Phonology, $§ 9$.

WESTON.

$$
\begin{aligned}
& \text { I086 Westone, D.B. } \\
& \text { I } 268 \text { Wiston, Index. } \\
& \text { I } 302 \text { Weston, F.A. }
\end{aligned}
$$

The meaning is obvious. If the spelling Wiston is genuine, the change from $e$ to $i$ must be explained as caused by the following $s$. 
WHATTON.

$$
\begin{aligned}
& \left.\begin{array}{l}
\text { I086 Watone, D.B. } \\
\text { I284 Watton } \\
\text { I } 302 \text { Whatton }
\end{array}\right\} \text { F.A. }
\end{aligned}
$$

O.E. hwōete tūn, "the wheat-enclosure, or the farm near which wheat grows." The vowel of the first syllable underwent early shortening before $t t: \overline{\mathscr{e}}>\mathscr{e}>$ M.E. $a$. See the following name.

It has been suggested that the name is derived from water on account of the watery situation of the village, or from wathtun, wath being a Scandinavian word for "ford," because there still exists in the locality a ford across the river Smite. But both these interpretations fail to account for the initial wh which cannot be merely a late fanciful spelling.

WHEATLEY.

$$
\begin{aligned}
& \text { I086 }\left\{\begin{array}{l}
\text { Wateleie } \\
\text { Wateleia } \\
\text { Watelaie }
\end{array}\right\} \text { D.B. } \\
& 1278\left\{\begin{array}{l}
\text { Wetele } \\
\text { Wetelay }
\end{array}\right\} \text { H.R. } \\
& \left.\begin{array}{l}
\text { I302. Westley } \\
\text { I3I6 Whetleye }
\end{array}\right\} \text { F.A. } \\
& \text { I 327-77 }\left\{\begin{array}{l}
\text { Weteley } \\
\text { Whiteley }
\end{array}\right\} \text { Non. Inq. }
\end{aligned}
$$

O.E. in hwēte lēaze, "in the wheat field." $a$ in D.B. stands for O.E. $\bar{e}$, M.E. $\bar{e}$. Westley and Whiteley are spellings obviously caused by false etymology.

WIDMERPOOL [locally: windəpul ; otherwise: widməpūl].

$$
\begin{aligned}
& \text { I086 }\left\{\begin{array}{l}
\text { Wimarspol } \\
\text { Wimarspold }
\end{array}\right\} \text { D.B. } \\
& \text { I } 89 \text { Widmespol, P.R. } \\
& \text { I } 284 \text { Witmerpol } \\
& \text { I428 Wodemerpole }\} \text { F.A. } \\
& \text { I } 57 \text { I Widmerpole, Index. }
\end{aligned}
$$

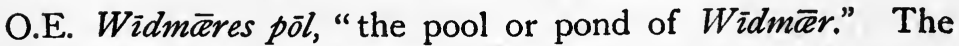
loss of the genitival $s$ is a remarkable feature of the development of this name. Popular etymology is responsible for various 
interpretations embodied in the early spellings. The second syllable of the pers. n. was taken for mere, "lake, pond," and the first was connected with the adjective white (F. A. I284), and the noun wood. Two different explanations are offered by Thoroton, who thinks that the name means either "Wimears Poll or Spear, or Wide mere Poole" (I, 77).

The metathesis of $d m$ in the local pronunciation is unusual: $d m$ became $m d$, the $m$ being afterwards turned into $n$ through assimilation.

The final $l d$ of the second D.B. form is puzzling. It is not impossible that it stands for $d l$, the suffix being pudel, puddle instead of $p \bar{o}$. Metathesis of $d$ is not infrequent in D.B. (Stolze, $§ 30$ ).

\section{WIGSLEY or WiggeSLEY.}

$$
\begin{aligned}
& \text { I086 Wigesleie, D.B. } \\
& \text { I } 60 \text { Wiggesley, Index. } \\
& \text { I } 302 \text { Wyggesleye, F.A. }
\end{aligned}
$$

The suffix is O.E. leah, "a field." The pers. n. involved may be either O.E. Wicga or Scandinavian Vigi. The former is found in O.E. sources; the latter occurs in Scandinavian records (Rygh, G. Personnavne, s.v.).

\section{WIGTHORPE.}

No early forms. The meaning of the second element is clear. The first element may be either of the pers. ns. mentioned under the preceding name.

WILFORD.

I086 Wilesforde, D.B.

I 84-I204 Wileford, Woll. MSS.

I 302 Wilford, F.A.

Probably O.E. Willan ford, "the ford of Willa, leading to Willa's habitation." The $s$ of D.B. is spurious (cp. Zachrisson, pp. I I 8, I I9).

In White's Directory (I853, p. 405) the following note on the etymology of this name is found: "The church...is dedicated 
to St Wilfrid, and the name of the village is evidently a contraction of Wilfrid's ford, as there is both a ford and a ferry close by." This statement confuses cause and effect; for if there exists any connection between the patron saint and the name of the village, the former must have been chosen in order to suit the latter.

WilloughBy.

$$
\begin{aligned}
& \left.\begin{array}{l}
\text { I086 } \\
\text { I } 56
\end{array}\right\} \text { Wilgebi }\left\{\begin{array}{l}
\text { D.B. } \\
\text { Index. }
\end{array}\right. \\
& \text { I } 204 \text { Wilghebi, Index. } \\
& \text { I } 29 \text { I Wilweby, Tax. Eccles. } \\
& \text { I } 302 \text { Willeugby }\} \text { F.A. } \\
& \text { I } 428 \text { Welughby }
\end{aligned}
$$

See following name.

WILLOUGHBY-ON-THE-WOLDS.

$1086\left\{\begin{array}{l}\text { Wilgebi } \\ \text { Willebi }\end{array}\right\}$ D.B.

c. I 80 Wilghebi, Woll. MSS.

I252 Wiliugeby super Wolde, Inq. P.M. I.

I363 Wilughbi super Waldas, Index.

"The $b \bar{y}(r)$ or dwelling among the willows." The suffix is of Scandinavian origin. The first element corresponds to modern English willow, whose M.E. ancestor is wilow, wilwe. In O.E., this word is found as weliz, wyliz, which normally would result in M.E. wily. We are, therefore, forced to assume that there existed in O.E. a variant containing a back vowel in the second syllable, *welug, wylug, ending in the back-open instead of the front-open consonant. The difference in the unstressed vowels is to be ascribed either to gradation (Sievers, $\$ 127,128$ ), or to the circumstance that the two nouns belonged to the 0 or $j o$ classes of strong masculines respectively. The mutated vowel of the one might have been transferred to the other.

The first named Willoughby is situated among low-lying meadows on a brook near which willows flourish abundantly. 
Wimpton.

$$
\begin{aligned}
& \text { I086 Wimunton, D.B. } \\
& \text { I } 168-9 \text { Wimunttun, P.R. } \\
& \text { I } 3 \text { I6 Wympton, F.A. } \\
& \text { c. I } 500\left\{\begin{array}{l}
\text { Wynton } \\
\text { Wympton }
\end{array}\right\} \text { Inq. P.M. c. I } 500 .
\end{aligned}
$$

The P.R. spelling is the most conclusive. This is not the "women's tün," but "the tün or farmstead of Winemund." This O.E. man's name is recorded once in the Onomasticon, as borne by an "amicus" of Eadbeald, king of Kent. Cp. Winthorpe.

$n$ became assimilated to the following $m$ at a very early period. A similar fate happened to the $m$ at a later date when it came into contact with the dental $t$, which changed it to $n$; see Wynton (Inq. P.M. c. 1500). This form seems to have perished. Where the $m$ was retained, a glide developed between it and the following $t$ (Phonology, $\S \mathrm{I} 6$ ). The absence of the genitival $s$ is noteworthy.

WINKBURN Or WINKBOURNE.

$$
\begin{aligned}
& \text { I086 Wicheburn, D.B. } \\
& \text { I I } 53 \text { Winkeburn, Index. } \\
& \text { I I } 89\left\{\begin{array}{l}
\text { Winkerburn } \\
\text { Wincheburn }
\end{array}\right\} \text { P.R. } \\
& \text { I } 278\left\{\begin{array}{l}
\text { Winckeburne } \\
\text { Wingeburne }
\end{array}\right\} \text { H.R. } \\
& \text { I } 346 \text { Wynkeborn, F.A. } \\
& \text { I637 Winkborn, Map in Camden. }
\end{aligned}
$$

The etymology of this name is very doubtful. The inquiry is rendered more complicated by the fact that the little river flowing past the village is called Wink on modern maps, and Winkle by older writers, e.g. in White's Directory of 1853 (p. $52 \mathrm{I}$ ).

The suffix is O.E. burne, "spring, brook." The whole name originally applied to the water-course, the habitation or village on its banks being called "at Winkburn." The first element may have been an O.E. adjective *wincol, derived from the root 
contained in wincian, "to wink, blink," and O.H.G. winchan, whose original sense was "to bend." Similar adjectival formations are numerous in O.E.; an alternative ending is -er, -or which is occasionally interchangeable with -ol, as in wacol, wacor, "vigilant." The meaning of O.E. *wincol would be "winding, pliant," which might very well be applied to many brooks. The variant *wincor would account for the first P.R. spelling, unless the first $r$ stand for $l$, as these two liquids are frequently interchanged in records compiled by Norman scribes.

The river-name Winkle can be explained as a back-formation from Wincel burn, "the winding brook." The modern name Wink probably came into existence by the same process but at a later date, when $l$ had disappeared in the pl. $n$. By a similar method the river-name Maun was deduced from the town Mansfield (q.v.).

WINTHORPE.

I086 Wimuntorp, D.B.
I 65-1205 $\left\{\begin{array}{l}\text { Wimethorp } \\ \text { Wimetorp } \\ \text { Winetorp }\end{array}\right\}$ Index.

I29 I Wymthorp, Tax. Eccles.

I3I6 Winthorp, F.A.

"The hamlet of Winemund." The same pers. $n$. forms the first element of Wimpton (q.v.).

WISETON or WYESTON [wistn].

$$
\begin{aligned}
& \text { I086 Wisetone, D.B. } \\
& \text { I278 Wiston, H.R. } \\
& \text { I304 Wystone, Index. } \\
& \text { I316 Wyston, F.A. }
\end{aligned}
$$

It is clear that the ending represents O.E. tün, "homestead," and that the first element is a pers. n. O.E. Wisa is not quoted in the Onomasticon as having been borne as a name by any known person. We may, however, safely assume that it existed. The meaning of Wisa is "the wise one" or "the leader." O.E. $W \bar{i}$ san tün seems to have developed in two different directions. 
The $n$ was lost in both cases according to a general rule. The $e$ of the second syllable was either retained or dropped. In the former case the $\bar{\imath}$ stood in an open syllable and remained long as in the modern spellings; in the second case, $\bar{\imath}$ before $s t$ was shortened, giving rise to the modern pronunciation.

\section{WithaM (river).}

The suffix may be an O.E. *amma, a somewhat doubtful name for a river, probably of Celtic origin, see Middendorf, s.v. The first element may represent O.E. wījig, "willow." This conjecture receives further support from the fact that the banks of the above river must at one time have been famous for the abundance of osiers, as the village of Barnby situated on it has received the distinctive addition of "in-the-willows." Thus the meaning is "the willowy stream." Names like Weidenbach of the same meaning are of frequent occurrence throughout Germany.

\section{WIVERTON [W̄̄tn].}

I086 Wivretune, D.B.

c. I 80 Wiverton, Woll. MSS.

$\left.\begin{array}{ll}\text { I } 284 & \text { Veverton } \\ \text { I } 302 & \text { Wyverton }\end{array}\right\}$ F.A.

I637 Waerham, Map in Camden.

1704 Waerton, Map.

$\left.\begin{array}{l}\text { Wiverton (commonly called) } \\ \text { Werton }\end{array}\right\}$ Thoroton, I, I95.

The first element of this name must be a pers. n., either O.E. Wigferb, Wigfrib, or Widfara, the last of which is claimed to be of Scandinavian origin by Dr Björkman. It occurs in a shortened form as Wiuare, Wifare in D.B., which exactly corresponds to the early spellings above. The suffix is, of course, O.E. tiun, "homestead"; Camden blunders by substituting -ham. The absence of any sign of a genitival ending need not disturb us. After the loss of $v$, ir developed in the regular way (Phonology, §8). 
WoLDS (a range of hills).

1252 Wolde, Inq. P.M. I.

I 363 Waldas, Index.

I6I3 $\left\{\begin{array}{c}(\text { the large, and goodly } \\ \text { full-flocked) oulds }\end{array}\right\}$ Drayton's Polyolbion.

From O.E. (Mercian) wáld, "forest." $a$, which had become lengthened before $l d$, was changed into $\bar{Q}$ in M.E. Drayton's spelling represents a dialect pronunciation, showing loss of initial $w$ before a rounded back vowel (cp. ooze<M.E. wose, Horn, $§ 173$ ).

The above word is identical with Southern English Wealds which is descended from the W. Saxon and Kentish variant weald. The development of senses can be easily traced. When the plains had been practically cleared of woods and forests, the word weald, wald was gradually restricted to the hills still covered with trees.

WoLlatoN [wulətn].

$1086\left\{\begin{array}{l}\text { Ollavestone } \\ \text { Olavestune } \\ \text { Waletone }\end{array}\right\}$ D.B.

I 216-1307 Wullaveton, Testa de N.

1284 Weleston)

$\left.\begin{array}{ll}\text { I } 302 & \text { Woleton } \\ \text { I } 316 & \text { Wolaton }\end{array}\right\}$ F.A.

1 327-77 Wolaston, Non. Inq.

I428 Willaton, F.A.

The spelling of Testa de $\mathrm{N}$. is the most helpful; if it contained the $s$ found in some others it would be perfect. The O.E. prototype was Wulfläfes tün, "the homestead of Wulfiaf." This pers. n. occurs frequently in O.E. documents. The loss of the genitival $s$ is noteworthy.

The D.B. scribes found it impossible to render the sound of $w u$ and often blundered over it (see following name). The spellings containing $a, e$ or $i$ in the first syllable are clerical mistakes and require no explanation. 
WOODBOROUGH.

$$
\begin{aligned}
& \text { I086 }\left\{\begin{array}{l}
\text { Udeburg } \\
\text { Udesburg }
\end{array}\right\} \text { D.B. } \\
& \text { I278 Wodeburg, H.R. } \\
& \text { I302 Wodeburgh, F.A. } \\
& \text { I637 Woodbro, Map in Camden. }
\end{aligned}
$$

"The fortified place in the wood," from O.E. wudu, "wood," and buruh, "fortified place." The development is regular. The $s$ in the second D.B. spelling is spurious; the scribe probably took the first element for a pers. $n$. Camden records the contemporary pronunciation.

WOODCOTES.

$$
\text { I } 302 \text { Wodicotes, F.A. }
$$

"The cottages in the wood," O.E. $b \vec{a}$ zundize cotas. The second syllable of the adjective wudiz, "woody," has been lost altogether.

\section{WOOLLEN.}

I suggest that the suffix is the same as in Meden, and Witham (qq.v.). If so, the first element might be O.E. wulf, "wolf," and the meaning of the compound "wolf stream." In O.H.G. a corresponding Wolfaha is found, modern Wolfach (Förstemann, II).

WORKSOP [wasəp] (Worsop, Wossap, Wursup, Hope).

$$
\text { Type } I \text {. }
$$

I086 $\left\{\begin{array}{l}\text { Werchesope } \\ \text { Werchessope }\end{array}\right\}$ D.B.

I 89 Wërchessope, P.R.

$$
\text { Type II. }
$$

I 89 Worcheshope, P.R.

I 4 IO Worsope, Index.

$$
\text { Type III. }
$$

1302 Wirksop, F.A.

I327-77 Wyrksop, Non. Inq. 
I 345 Wirkesop, Index.

I 346 Wirsop, F.A.

\section{Type IV.}

I 535-43 Werkensop, Leland, I, 99.

I637 Workensop, Camden, p. 550.

The termination in Types I, II, III apparently is O.E. hop, "valley." The first element is a pers. n., of which there is no record in the Onomasticon, it is true, but whose existence is proved by its being contained in a number of pl. ns. enumerated by Prof. Moorman, s.v. Worksborough. That name seems to have occurred in various forms, namely as Wyrc (Type III), Weorc (Type I), and Worc (Type II). The last form evidently developed out of the second on or near Northumbrian territory, where the change from weo to wo took place (Bülbring, $\S 265$ ).

The modern spelling goes back to Type II, so do the first and the second pronunciations recorded by Hope. The pronunciation in square brackets is descended from either Type I or III, ir, er first becoming $[\bar{\Lambda}]$ as in the last of Hope's forms, and then being shortened.

Type IV is puzzling. The two spellings are too late and can hardly be taken seriously. It is, moreover, very probable that Camden partly copied from Leland. One might feel tempted to say that the $n$ represents the genitival ending of a weak variant of the pers. n. Weorca; but the presence of an additional $s$ renders that impossible.

WySALL [waisə].

\section{Type I.}

I086 Wisoc, D.B.

\section{Type II.}

1302 Wishow, F.A.

1327-77 Wysowe, Non. Inq.

I428 Wyshow, F.A.

I476 $\left\{\begin{array}{l}\text { Vyssow } \\ \text { Wysow }\end{array}\right\}$ Index.

I 535 Wyshawe, Valor Eccles.

1637 Wysshaw, Map in Camden. 
The suffix is the same as in Watnall (q.v.); D.B. writes final $c$ instead of $h$ in hosh, "hill." The nature of the prefix is extremely doubtful. It might stand for the pers. n. Wisa, found in Wiseton. If so, the meaning of O.E. Wisan hoh would be "Wisa's hill."

The development of the suffix and the recent substitution of -all for the ending are explained under Watnall.

If the explanation offered is correct, one would expect the $s$ to be voiced. I cannot satisfactorily account for the quality of that consonant.

In the spellings of 1535 and 1637 , shaw, from O.E. sceaga, "small wood, copse, thicket," is substituted for the original suffix. These forms are too recent to be classified as a genuine type. 


\section{PHONOLOGY OF THE NOTTINGHAMSHIRE PLACE-NAMES}

here.

N.B. Only those sound-changes that are of special interest have been classified

\section{Vowel Changes.}

$\S$ I. Shortening of original long vowels in stressed syllables before certain consonant combinations.

(a) Late O.E. shortenings :

$\overline{\mathbf{a}}>\mathbf{a}$ : Aslockton $<\bar{A}$ slac; Bradmore $<$ brād-; Stanton, Stanford $<$ stān.

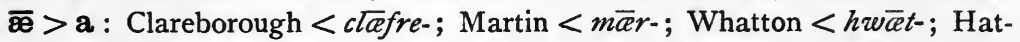
field $<h \bar{a} b$-.

$\overline{\mathbf{e}} \mathbf{a}>\mathbf{a}$ : Radford, Ratcliffe $<$ rēad .

$\overline{\mathbf{e}}>\mathbf{e}$ (W. Sax. $\bar{a}$, Mercian $\bar{e})$ : Fledborough $<$ Flēda; Strelley $<$ strèt- ; Sturton, older Stretton $<$ strēt-.

ēo $>$ e : Darlton $<*$ derl- $<$ Dëorl-.

$\overline{\mathbf{1}}>\mathbf{i}$ : Limpool, Linby $<$ lind-.

$\overline{\mathbf{0}}>\mathbf{0}$ : Broxtow < Brōcwulf-; Hokerton < Hōkr: Ossington < Oskin-.

$\overline{\mathbf{u}}>\mathbf{u}$ : Dunham $<$ dīn- ; Rufford $<$ rīh-; Southwell [saøl], Sutton $<$ sǜ- ; Plumtree $<$ plüm.

(b) Early M.E. shortenings :

ēa $>\mathbf{e}:$ Edwalton, Edwinstow $<\bar{E}$ ad-; Retford $<$ rēad-.

$\overline{\mathbf{e}}>\mathbf{i}$ : Gringley $<$ grên ; but see $\S 6$.

$\S$ 2. The regular development of O.E. $\overline{\mathbf{a}}$ is M.E. $\bar{\phi}$, modern [ou]: Gotham < gāt-; Goverton < Gärfrił- ; Grove < grāfe.

$\S$ 3. M.E. ih seems to have developed into late M.E. $\bar{\imath}$ which did not participate in the diphthongisation of early M.E. $\bar{i}$ from O.E. $\bar{i}, \bar{y}$, $i \dot{g}$ : Kneesall, Kneeton < kniht-(?). In the Dialect Grammar (\$77) it is stated that this change has taken place in Northumberland, Durham, Cumberland, Westmoreland, Yorkshire, Lancashire, Cheshire, Flintshire, and parts of Staffordshire, Derbyshire, and Lincolnshire. As Nottinghamshire is situated between Yorkshire, Derbyshire, and Lincolnshire, it is not unreasonable to. assume that the same sound-change has taken place within its territory. The Nottinghamshire dialect is very badly represented in the Dial. Dict. ; I am informed that old people still pronounce night as [nit], but that 
otherwise the standard pronunciation has supplanted the genuinely local forms. See Horn, $\S 69$ anm.

$\$$ 4. M.E. $\overline{\mathbf{u}}$ is derived from various sources and has developed on various different lines. (I) O.E. $\bar{u}$ has undergone diphthongisation in: Lound $<$ lund,

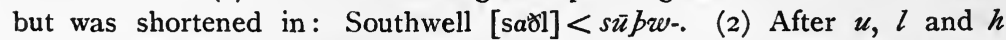
became vocalised ; the resulting combination $u u$ was then treated as older $u$, i.e. diphthongised to [au]. The first change has taken place in: Boughton $<$ buhtün, and Bulcote $<b u l-$, but $\bar{u}$ was not diphthongised through influence of the initial labial consonant; $\mathrm{cp}$. the pronunciation of wound.

M.E. $u$ from $u l$ has become shortened at a later period in: Sowlkholme $[$ sakm $]<$ sulh-.

In Oldcoates < $\bar{u} l e-$, M.E. $\bar{u}$ seems to have developed into modern [ei], the pronunciation of that name being given as Alecotes in Hope's Glossary. This may represent the genuine dialect pronunciation, for which, however, I cannot find any confirmation.

$\S$ 5. Early M.E. $æ$, a appears as both $e$ and $a$ before original ks: Laxton, older Lessington < Leax-; cp. Dial. Grammar, § 25 .

$a$ seems to have been lengthened before $s$ in: Basford [beisfad] < Bassa-; this M.E. change corresponds to a similar lengthening of $a$ before open voiceless consonants in modern southern English, in words like mass, grass, path.

$\S 6$. M.E. $\mathrm{e}$ has become $i$ before $n g[\mathrm{\eta}]:$ Bingham < Benninga-; Finningley $<$ fenninga-. Cp. Dial. Gramm. $\S 55$, Horn, $\S 38$.

$\S 7$. M.E. er and ar developed into ar; after this change had taken place, the $r$ was lost before the dental and blade consonants $s, p, l, n$, the $a$ being lengthened at the same time: ers, ars $>$ ars $>\bar{a} s$. This $\bar{a}$ is represented by modern [ei], or [æ] if shortened: Bassetlaw, Caythorp, Dalington, Danethorpe, Perlethorpe, older Palethorpe, Staythorpe: see discussions and forms under each name above.

$\S 8$. M.E. er, ir, and ur have all become $[\bar{\Lambda}]$ in the modern pronunciation; in some cases, however, er, ar are represented by ar and [ei]; see $\S 7$. The early spellings of some of the following place-names prove that this transition took place at a somewhat earlier date than is usually assigned to it; see Barnston, Barton, Carburton, Darlton, Girton, Harby, Serlby, Sherwood, Sturton, Wiverton, Worksop.

$\S$ 9. M.E. au and ou. The combination al developed into aul; the $l$ is retained in the modern spelling of: Balderton, Calverton [kJvvatn, kāvətn], and Halloughton [houtn, h̄̄tn]; it has been lost in: Caunton < Caln-, and Awsworth $<$ Aldes-. M.E. $\bar{q}<a u$ was shortened in: Ollerton and Ompton < alr-, alm-.

ol has become [oul] in: Rolleston; it is represented by [j] in Hawton $<$ holt-. This latter fact seems to prove that, in the dialect, M.E. au and ou have fallen together. The spelling Hauton for older Holton is found as early as 1270 .

Scand. ou appears as $\bar{\delta}, O$ in: Haughton, Hockerton; cf. Björkman, Scand. Loan Words. 
$\S$ 10. Shifting of accent is found in: Keyworth and Trowell (qq.v.).

$\S$ II. Norman influence accounts for the change from an to aun in: Maun, Saundby, Staunton.

\section{Consonant Changes}

$\S$ I2. Loss of Consonants. Of three consonants, the middle one is lost, this change being due to assimilation in most cases.

d : Bilsthorpe $<-l d s-;$ Bonbusk $<-n d b-;$ Chilwell $<-l d w-;$ Felley $<-l d l-$;

Shelford $<-l d f$ -

f: Wollaton $<-l f l$ -

k : Kirton $<-r k t-$; Radcliffe [rætlif] $<-t k l-;$ Syerston $<-r k s-;$ Worksop

[wasəp] $<$ rks-.

1: Gamston $<-m l s t$-.

n : Milton $<-\ln t$.

t: Beeston [bīsn] $<-$ stn-.

p, $\boldsymbol{\delta}$ : Normanton $<-r \delta m-;$ Norney $<-r \delta r n-;$ Norton $<-r b t$; Norwell,

Torworth $<-r \delta w-;$ Wiverton $<-r b t$.

$\nabla$ : Elston <-lvst-; Scarle <-rvl-; Selston <-lvst-.

$\S$ 13. Assimilation.

$l d>l l$ : Bole, Bolham, Rolleston.

$d k>k k>k$ : Eacring $<\bar{E} a d(w a) c e r$.

$f n>m n:$ Rampton $<*$ Hrafntün.

hf $>\not f:$ Rufford < rühford.

sk>ss: Ossington < Oskintūn; Bothamsall <-skeld.

$k s>s s$ : Laxton, older Lessington.

$k b>b(b)$ : Huthwaite $<-k b w$.

$k t>t t$ : Boughton (Button, Type III) < buktün.

$t w>k w$ : Bestwood, older Beskwood.

$m s>n s:$ Mansfield $<$ Mams-.

$n m n p>m b>n b:$ Winthorpe $<$ Winemund porp.

$n \eta>\eta(\eta)$ : Bingham $<$ Benning-.

$n m>m(m)$ : Wimpton $<$ Winmun-; Kimberley $<$ Cynmār - .

$n d p>n p>m p:$ Limpool < lindpōl.

$\eta t>n t:$ Dalington [dælintn].

stw > skw: Bestwood, older Beskwood.

ts $>$ ss: Cossal $<$ Cots-.

$t l>d l>l l:$ Strelley $<$ strêtleze; Teversal $<-$ holt.

$r s>s(s)$ : Syerston (Type II).

$r \delta>r r$ : Scarrington $<-r \delta$.

$b t>t t:$ Sutton.

$b-n>b-m$ ("Fernassimilation," see Horn, § 228 anm.): Bramcote $<$ bran (d) cot; Brinsley, see Testa de N. spelling.

$n$ in the second syllable of trisyllabic words has become $\eta$ in a number of place-names. This second syllable had very weak stress, and I assume that this vowel, of whatever origin, became $\breve{l}$ at a very early period. This high 
front vowel exercised an assimilatory influence upon the $n$, changing the dental nasal into the front nasal (retracted). A similar change is observed in the M.E. present participle bindinde becoming bindinge. This transition is usually ascribed to the influence of the corresponding verbal nouns in -inge (Sweet, N. Engl. Gramm. § 1239), but it may have been assisted and accelerated by the operation of the sound-law formulated above. Other writers on place-names assume that the change from -an-, -en-, -in- to -in-is due to analogy with names containing an original patronymic particle -ing(Wyld, Place-Names of Lancashire, p. 36, see Alexander, Essays and Studies, II, pp. 158 sqq.). There are two circumstances which speak against such an explanation: (I) The large number of -ing-forms derived from -in(Alexander, l.c. p. I8I). (2) The existence of modern vulgar pronunciations exhibiting a similar transition in independent words, as skelington (skeleton, older *skelenton, cf. celandine < Latin celidonia, etc., Horn, $\S 225$ ), and sartingly (certainly). Examples of Nottinghamshire place-names are: Edingley $<\bar{E}$ adrwin- ; Attenborough (see older forms); Farndon (see older forms); Kilvington (?); Kirklington (?); Laxton, older Lessington < Leaxan-; Newington $<$ nïwantīine; Ossington $<\bar{O}$ skin-; Wallingwells $<$ wallend $(e)$-.

$\S$ I4. Dissimilation. Loss of $r$ through influence of another $r$ contained in the same word is found in: Goverton, and perhaps in: Ordsall (qq.v.). The loss of $n$ in Misterton < mynstertūn may be due to the dissimilatory effect of the initial $m$. (Cp. Zachrisson, pp. I 36 sqq.; Horn, § 237.)

$\S$ I 5 . Metathesis.

$r$ frequently changes its place in the accented syllable: Girton $<$ grēot-;

Scrooby < scurva-; Sturton <strēt-; Thrumpton $<$ burmōd-; Treswell $<$ tires-.

$n(m)$ changes its position in: Widmerpool [windəpul] $<W i d m \bar{e} r$ -

$\S$ i6. Development of a glide.

$m t>m p t$ : Ompton, Plumtree, older Plumptre, Rampton, Thrumpton Wimpton.

$m s t>m p s t:$ Rempston.

$m r>m b r:$ Kimberley.

$p l>p w l$ : Cropwell.

$\S$ 17. Voicing and unvoicing, due to partial assimilation.

$d k>t k:$ Ratcliffe $<$ réad-.

$d f>t f:$ Retford $<$ réad-

$h b>p$ : Epperston <*Eohberht- (?).

$t b>d b$ : Budby $<B u t$ -

$\S$ I8. Loss of $\mathbf{h}$ and $\mathbf{w}$ at the beginning of an unstressed syllable. $h$ is lost : Cossal <-hale; Cropwell <-hill; Nottingham [notijm], etc. $w$ is lost: Colwick [kolik]; Bulwell [buləl]; Eakring $<\bar{E}$ adwacer-; Edwinstow, or Edenstow ; Harworth [hærəp]; Kinoulton $<$ Cynweald-; Norwell [norəl]; Southwell [saðl]. 
$\S$ 19. Initial $h$ is a very unstable element in the Nottinghamshire dialect. It is usually dropped in pronunciation, but may be prefixed to any stressed word beginning with a vowel: Appesthorpe, Hickling, Hockerton, Hoveringham.

$\S$ 20. $\mathbf{k t}>$ ht.

Whenever in the older Germanic languages $k$ and $t$ met in combination, the former was opened and changed into the back or front spirant. This same sound-law seems to have been in operation throughout the O.E. ${ }^{1}$ and M.E. periods, unless crossed by analogy. Prof. Wyld was the first to draw attention to this interesting fact (Place Names of Lancashire, p. 32). Examples are: Boughton $<{ }^{*}$ Buktūn; Haughton $<{ }^{*}$ Hōktūn.

$\S 21$. Final $l$ is lost in the modern local pronunciation of Southwell [saðə]; Hucknall [haknə]; Watnall [wotnə]; Wysall [waisə]. On the other hand, an excrescent $d$ was added to Arnold < Earn hale; see Dial. Gramm. $\S 306$; Horn, $\S 188$.

$\S 22$. Norman Influence. The inability of the Normans to pronounce $\vec{b}$ caused them to substitute $t$ for that sound. Initial $t$ for $b$ has persisted in : Tollerton, Torworth, Toton, Treswell (qq.v.). (Zachrisson, pp. 39 sqq.)

They simplified the initial combination $s n$ by dropping the $s$ in Nottingham < Snotingahäm. (Zachrisson, pp. 51, 55.)

$\S 23$. Scandinavian Influence accounts for the irregular development of O.E. $\dot{g}$ and $\dot{c}$, and $\dot{s} \dot{c}$ in the following cases : Egmanton $<E \dot{c} \dot{g}_{-}$; Lindrick <-rìc; Fiskerton < fisiere- (?); Muskham < Musica- (?).

1 A late O.E. example of this change is lēhtün "garden" (c. 950, Lindisf. Gosp.) $<$ lëactūn; see N.E.D., s.v. leighton. 


\section{WORDS OTHER THAN PERSONAL NAMES IN THE NOTTINGHAMSHIRE PLACE-NAMES}

\section{Words OF ANGLO-SAXON ORIGIN}

$\bar{a} c$, oak-tree (Hodsock, Shireoaks)

$\bar{a} d r e$, spring, channel of water (Averham)

assi, ash-tree (Ashfield, Askham)

$b a b$, bath (Bathley)

bearo, wood, forest (Bassetlaw)

beofor, beaver (Bevercotes)

beorg, hill, mountain (Flawborough)

beretūn, barley-enclosure, farmstead (Barton, Carburton)

blì $x$, blithe, gentle (Blyth)

bold, botl, house, dwelling (Bole, Bolham, Newbold)

brā $d$, broad (Bradmore, Broadholme)

*brand, forest land cleared by fire (Bramcote)

brōc, brook (Daybrook, Giltbrook)

$b r y \dot{c} g$, bridge (Bridgford)

bul(e), bull (Bulcote)

*bullan, to bubble (Bulwell)

bune, calamus, canna (Bunny)

burh, fortified place (Attenborough, Bilborough, Brough, Burton Joyce, Clareborough, Fledborough, Littleborough, Woodborough)

burne, spring, brook (Winkbourn)

cealf, calf (Calverton)

* cild, spring, fountain (Chilwell)

cläfre, clover (Clareborough)

clag , clay (Clayworth, Sturton-in-the-Clay)

clif, rock, cliff (Clifton, Radcliffe, Ratcliffe, Rushcliff)

cot, house, cot, habitation of human beings and animals (I : Bramcote, Coates, Cotham, Cottam, Oldcoates, Woodcotes; 2 : Bevercotes, Bulcote, Lamcote)

crumb, crooked, winding (Cromwell)

cucu, creic, quick, fast, alive (Cuckney)

cumb, deep hollow or valley (Sowlkholme)

$c \bar{y}$, form of $c \bar{u}$, cow (Keyworth)

cyne-, royal (Kingston) 
denu, valley (Saxondale)

dìc, ditch (Bycardyke, Heck Dyke)

draca, dragon (Drakeholes)

dregg, retreat, nook (Drayton)

dūn, hill (Dunham, Farndon, Headon)

$\bar{e} a$, $\bar{e} \dot{g} e$, water meadow, island ; river, stream (Blyth, Bunny, Cuckney,

Drinsey Nook, Eaton, Greet, Idle, Lithe, Mattersey, Norney, Tilne)

*ealce, a mythological person (Awkley)

eald, old (Oldwark Spring)

éast, east (Eastwood)

fearn, fern (Farndon)

feld, open country, as opposed to woodland ; a plain (Bassingfield, Farnsfield,

Felley, Haggonfield, Hatfield, Kirkby-in-Ashfield, Mansfield, Netherfield)

fenn, mud, dirt ; fen (Fenton, ? Finningley)

fiscere, fisherman (Fiskerton)

fint, rock (Flintham)

ford, ford (Basford, Bridgford, Flawford, Gateford, Hazelford, Langford,

Radford, Retford, Rufford, Salterford, Shelford, Spalford, Stanford,

Stapleford, Wilford)

$f u ̈ l$, dirty, soiled ; miry (Fulwood)

gadeling, companion in arms (Gedling)

gāra, triangular piece of land (Langar)

gät, goat (Gotham)

graf, graf, grave, burial-place (Cotgrave, Grove?)

grā , grove (Grove ?)

grēne, green (Gringley?)

grēot, sand, rubble (Girton, Greet)

gylden, golden (Giltbrook)

hasel, hazel (Hazelford, Hesley)

$h \bar{e} p$, heath (Hatfield, Headon)

hãm, home ; see special article, p. 169 ; (Beckingham, Bingham, Collingham,

Dunham, Flintham, Gotham, Hoveringham, Lowdham, Markham,

Marnham, Muskham, Nottingham, Walkeringham)

healh, nook, valley; see special article, p. 169; (Arnold, Cossal, Hallam,

Halloughton, Hucknall, Kersall, Kneesall, Nuthall, Ordsall)

hege, haga, hedge, fence; a piece of enclosed ground (Bilhagh, Haywood Oaks, Thorney, Wellow)

held, slope, declivity (Merrils Bridge)

here, army (Harwell?)

hierde, Anglian heorde, shepherd (Harby)

hläw, hill, mound (Bassetlaw) 
*hlüd, stormy? (Lowdham)

$h \bar{h} h, h \bar{g} g$, hill, mound ; tumulus (Watnall, Wysall)

hol, hole, cave, den (Drakeholes)

hol( $h$ ), hollow (Holbeck)

holt, wood, copse (Hawton, Teversal)

*hop, valley (Styrrup, Warsop, Worksop)

hors, horse (Horsepool)

hweete, wheat (Whatton, Wheatley)

hyll, hill (Cropwell)

hyrst, grove, wood (Lyndhurst)

lamb, lamb (Lambley, Lamcote)

land, plough-land (Langford)

lane, lane, street (Laneham)

lang, long (Langar)

lēah, meadow, field; see special article, p. I70 ; (Annesley, Awkley, Baggalee,

Bathley, Brinsley, Edingley, Elkesley, Felley, Finningley, Greasley,

Gringley, Hesley, Kimberley, Lambley, Rockley, Scarle, Strelley,

Wansley, Wheatley, Wigsley)

lind, lime-tree (Limpool, Linby, Lindrick, Lyndhurst)

liðe, lithe ; smooth, still (Lide)

lỹtel, little, small (Littleborough)

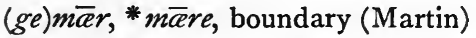

mapuldor, maple-tree (Maplebeck, Mapplewell)

mearc, boundary (Markham)

mere, lake, pool (Bradmore, Gibsmere)

middel, middle (Middlethorpe)

mōr, moor (Barnby Moor, Morton)

mylen, mill (Milnthorpe, Milton)

mynster, monastery, church (Misterton)

myrige, pleasant, agreeable, delightful (Merrils Bridge)

neoderra, lower (Netherfield)

netele, nettle (Nettleworth)

niurve, new (Newark, Newbold, Newington, Newstead, Newthorpe, Newton)

nor $\delta$-, north (Norton, Norwell)

norderne, northern (Norney)

$o x a$, ox (Oxton)

papol, pebble (Papplewick)

plüm-trēo, plum-tree (Plumptree)

pōl, pool, pond (Horsepool, Limpool, Widmerpool)

rēad, red (Radcliffe, Radford, Ratcliffe)

*ric, wood, forest ; tract of land? (Lindrick) 
risi, rysi, rush (Rushcliff)

rïh, rough (Rufford)

$s \bar{e} t a$, settler, dweller; inhabitant (Bassetlaw)

*sceld, shallow (Shelford)

scìr, boundary (Sherwood)

scylfe, Anglian scelfe, shelf, ledge (Shelton)

sealh trēo, sallow-tree (Salterford)

spring, spring, fountain (Oldwark Spring)

stān, stone (Kingston, Stanford, Stanton, Staunton)

stapol, pillar (Stapleford)

stede, place (Newstead)

stiepel, Anglian stēpel, steeple (Sturton-le-Steeple)

* stoc, stocc, stump of a tree, stake; enclosed place ; log hut? ; stockade? see discussion under Stoke Bardolph; (Costock, Stockwith, Stoke Bardolph, East Stoke, Stokeham)

stōw, place; holy place (Broxtow, Edwinstowe)

strāet, street, paved road (Strelley, Sturton)

* sulh, miry place, swamp (Sowlkholme)

sï̌s, south (Southwell, Sutton)

trēoze, tree (Plumptree, Trowell)

tün, enclosure ; farmstead, see special article, p. 171 ; (Adbolton, Alverton, Aslockton, Babbington, Balderton, Barnston, Barton, Beeston, Bonnington, Boughton, Broughton, Burton Joyce, West Burton, Calverton, Carburton, Car Colston, Carlton, Caunton, Clifton, Clipston, Coddington, Colston Basset, Dalington, Darlton, Drayton, Eaton, Edwalton, Egmanton, Elston, Elton, Epperston, Everton, Fenton, Fiskerton, Gamston, Girton, Glapton, Gonalston, Goverton, Grimston, Halloughton, Haughton, Hawton, Hayton, Hockerton, Kilvington, Kinoulton, Kirklington, Kirton, Kneeton, Laxton, Lenton, Leverton, Manton, Martin, Milton, Misterton, Morton, Newington, Newton, Normanton, Norton, Ollerton, Ompton, Orston, Osberton, Ossington, Oxton, Rampton, Rempston, Rolleston, Ruddington, Scarrington, Scofton, Screveton, Selston, Shelton, Sneinton, Stanton, Staunton, Sturton, Sutton, Syerston, Thoroton, Thrumpton, Thurgarton, Tollerton, Toton, Upton, Weston, Whatton Wimpton, Wiseton, Wiverton, Wollaton)

porn, thornbush (Thorney)

üle, owl (Oldcoates)

üp, above (Upton)

weald, Anglian wald, forest (the Wolds) wealh, slave, serf; Briton ; may be a pers. n. (Walesby) weallan, to boil ; to flow, go in waves (Wallingwells) weorc, worc, building; fortification (Newark, Oldwark Spring) 
*weor , wor b, enclosed homestead ; habitation ; see special article, p. I7I ;

(Awsworth, Babworth, Blidworth, Clayworth, Colsterworth, Harworth, Hawksworth, Keyworth, Littleworth, Nettleworth, Rainworth, Scaftworth)

west, west (Weston)

wiell, well, spring, fountain; stream (Bulwell, Chilwell, Cromwell, Harwell, Mapplewell, Norwell, Southwell, Wallingwells, Welbeck, Welham, Wellow)

*wiluh, *wilug, willow-tree (Barnby-in-the-Willows, Willoughby)

wiððig, willow (Witham)

wudig, woody (Woodcotes)

wudu, wood, forest (Bestwood, Fulwood, Haywood, Sherwood, Woodborough)

\section{WORDS OF SCANDINAVIAN ORIGIN}

bekk(r), brook (Beck, Bycardyke, Holbeck, Maplebeck, Oswardbeck, Welbeck)

birki-, birch (Birkland)

breiðr, broad (Bradebusk)

brekka, brink, slope (Brecks)

busk $(r)$, shrub ; bush (Bonbusk, Bradebusk)

$b \bar{y}(r)$, habitation, farm; village (Barnby Moor, Barnby-in-the-Willows, Bilby, Bleasby, Budby, Granby, Harby, Kirkby, Linby, Ranby, Saundby, Scrooby, Serlby, Skegby, Thoresby, Tythby, Walesby, Willoughby)

dal( $r)$, valley (Saxondale)

drengr, companion ; sergeant-at-arms, may be a pers. n. (Drinsey Nook)

drit, dirt, M.E. dritig, dirty (Dirty Hucknall, or Hucknall-under-Huthwaite)

geit, goat (Gateford)

$h e i \gamma(r)$, heath (Hayton)

hesli, hazel (Hazelford, Heseland (see Birkland), Hesley)

$\operatorname{holm}(r)$, island (Broadholme, Holme)

kelda, well (Bothamsall, Kelham, Ranskill)

kirkja, church (Kirkby, Kirton)

kjar $(r)$, M.E. ker, swamp, marshy ground (Carburton, Car Colston)

$k r o p p(r)$, hump (Cropwell)

Lōk(r), brook, rivulet (Leake)

lund $(r)$, wood, grove (Birkland and Heseland, Lound)

skjalf, ${ }^{*}$ skelf-, shelf ledge (Ranskill, early forms) 
porp, village, hamlet, see special article, p. I7I ; (Appesthorpe, Bagthorpe, Beesthorpe, Bilsthorpe, Caythorpe, Danethorpe, Gleadthorpe, Goldthorpe, Grassthorpe, Gunthorpe, Knapthorpe, Middlethorpe, Milnthorpe, Newthorpe, Osmondthorpe, Owthorpe, Perlethorpe, Sibthorpe, Staythorpe, Stragglethorpe, Thorpe-in-Glebe, Thorpe-by-Newark, Wigthorpe, Winthorpe)

pveit, a piece of land, a single farm, a hamlet (Eastwood, Huthwaite)

vað, a wading place, ford (Langwith?, Stockwith ?)

$v i \bar{k}$, bay, creek (Colwick, Papplewick)

$v i \delta(r)$, tree, wood, forest (Langwith?, Stockwith ?)

voll $(r)$, *valøuz, field (Trowell?)

\section{Words OF French and Latin Origin}

bellum (Low Latin), fair, beautiful (Beauvale)

beste, beast of the chase (Bestwood)

$f a b a$, bean (Barton-in-Fabis)

forest, wood not enclosed, forest (Lyndhurst-on-the-Forest)

glebe, Latin glēba, plough-land (Thorpe-in-Glebe)

grange, granary; outlying farm-house (Gleadthorpe Grange)

vallum, vale, valley (Beauvale)

\section{APPENDIX}

\section{SOME OF THE MORE FREQUENT SUFFIXES EXPLAINED}

(I) hãm. The meaning is clear: "home, house, abode, estate." It denotes the dwelling of some person of consequence, or the chief seat of a tribe or noble family. Bede renders the pl. n. Rendlasham by "mansio Rendili," where mansio stands in its Low Latin sense, from which both English mansion and French maison are derived.

(2) healh, dative hēale, häle, hale. Although this termination is of frequent occurrence in pl. ns., it is extremely difficult to give its exact signification. After careful consideration of the evidence, Professor Wyld arrives at the conclusion that it means "a hollowed-out area, a bay, retreat" (Place-Names of Lancashire, p. 340). Miller (Place-Names in Bede, pp. 38, 39) discusses this word at length ; he translates it by "recess, corner, hollow." I am inclined to go further than that and assign the meaning of "valley" to O.E. healh. This view is supported by geographical evidence : all the places containing this element seem to lie in a "hollow," or, at any rate, to be situated 
close to a valley where the original habitation may have stood. Bede's translation of Streones halh as "Sinus fari" has been a puzzle to many writers, and I do not propose to solve the mystery of the first element. Whether farus means "light-house" or not is a question that may perhaps never be decided. The signification of the second element is clear: sinus means, of course, "bay," but it has another sense as well, in which it is used here, namely that of "mediterraneus terrae angulus," as e.g. in the combination "vallium sinus." (Forcellini, Totius Latinitatis Lexicon, Schneeberg, 1831.) It describes a triangular piece of land forming the bottom of a valley between two hills or ranges that meet at one end. Such "corners, nooks, retreats, inland bays" or whatever the description may be, must have been the very spots to attract the early settlers. For they were more easily cleared of trees and undergrowth, if there were any, than the hill-sides; they were almost invariably watered by a small stream, and afforded shelter and protection.

As to the derivation of the word healh, I am inclined to connect it by gradation with O.E. holh, "hollow." The modern Frisian hallich, pl. halligen, I regard as identical1. Dijkstra (Friesch Woordenboek, Leeuwarden, 1900) gives its meaning as follows: "Kleine anbeduinde en onbedijkte eilandje aan de Noordfriesche kust,-overblijpselen van door de see verzwolgen land, waar de bewoners nog Friesch spreken." One usually connects the latter word with O.E. hyll etc., being under the impression that it refers to the artificial mounds, or "Werften," on which the houses of the "Halligen" are erected. This, however, is not correct. Originally, the term was applied to low-lying land not protected from the sea by dykes, and therefore subject to being flooded. I am told that the latter meaning is still the one attached to the word hallich by the islanders themselves.

(3) lëah, Mercian lëh, dative lège. This word is related to Latin lucus, "grove," and O.H.G. lôh, "brushwood, clearing"; the meaning of modern Germ. Loh is "grove, copse." The original sense is that of "clearing, open space in the wood." The development of senses in the German and Latin words is easily explained and affords another example of how completely the meaning of geographical terms may change. The lucus or clearing does not consist of the open space only, but it comprises also the surrounding trees. In course of time, the latter came to be regarded as the essential and characteristic feature, the word thus assuming the meaning of "collection of trees, grove."

In the modern dialects, lea is used in the following senses: "meadow, field, pasture, grassland." In the pl. ns., I have translated it by "field," which may refer both to grazing and arable land. In O.E. charters, lea $h$ is

${ }_{1}^{1}$ The development of a svarabhakti vowel between $l$ and $h$ is a regular feature of the Frisian language; see Siebs, "Geschichte der friesischen Sprache," \& 85, in Pauls Grundriss, $\mathrm{I}^{2}$. Prof. Siebs kindly informed me that, as far as sound-development is concerned, hallich might very well be identical with O.E. healh. 
rendered by Latin campus (see N.E.D., s.v.); Asser (Life of King Alfred, ed. Stevenson) renders Aclea by "in campulo quercus."

(4) tiin. This word is identical with O.H.G. zinn, modern Germ. Zaun, hedge, fence." Thus it originally referred to the paling or hedge with which the Teuton settler surrounded his homestead in order to protect himself and his beasts from the attacks of wild animals as well as of thieves. This original sense of the word appears clearly in the O.E. compound deortiin, "a deer enclosure, a frith, a park." Its application, however, became soon extended. It was used to denote not only the actual palisade or hedge, but everything inclosed by the latter, namely, the whole homestead or farm. That is still the meaning of the Scotch toon which the Dial. Dict. explains as "farmstead, farmhouse and buildings, country seat, single dwelling." In the latter senses, the suffix was used in the pl. ns., which accounts for the fact of so many of the names in -tün having a pers. $n$. for their first element. The modern meaning of the independent word town is a late development.

(5) borp. Although it is a fact that this word is found in O.E. before the Scandinavian invasion, I am inclined to regard it as of Norse origin when it occurs as the second element of pl. ns. Professor Wyld holds the view that it may be derived from either source. It makes its most frequent appearance in districts containing a large Scandinavian population, and is very often compounded with Norse pers. ns. Professor Moorman (Place-Names of the West Riding, p. xlv) points out that it is very common as a termination in Danish pl. ns., but is more rarely encountered in Norway and hardly at all in Iceland. This seems to explain the fact that there are but few examples of its occurrence in Lancashire where the Scandinavian element is largely of Norwegian descent, whereas it is much more frequent in the Danish districts of Yorkshire and Notts.

The meaning of borp is "village." Originally it described a collection of dwellings, and is thus opposed in signification to the single and more imposing habitations called $h \bar{a} m$, thin, and zeor $b$. Whereas the latter were owned by a person of consequence or occupied by a noble family whose "hall" or "seat" they were, the former seems to have been composed of the more humble cots and huts of serfs, common people, or the great man's retainers. It is noteworthy, however, that borp is frequently preceded by a pers. $\mathrm{n}$. in the singular; it is doubtful whether the latter referred to the lord and owner of the village, or whether the word porp had lost its primitive meaning and become identical with tün and häm denoting single dwellings.

(6) weorb, worb. The O.E. pl. n. Beodricesweor 8 is translated into Latin by "Bedrici curtis" (Passio Sancti Edmundi, c. 14). The meaning of Low Latin curtis is "enclosure, estate." Both the original meaning and the etymology of O.E. worb are obscure. Professor Skeat (Place-Names of Cambridgeshire, p. 25) connects it with O.E. weor b, "worth, value," which does not seem a very happy explanation. I venture to suggest that M.H.G. wert,-des, 
"island, peninsula, raised dry land between morasses," is a possible cognate. Dr Hirt (Weigands Deutsches Wörterbuch, s.v. Werder) derives wert from the root contained in Gothic warian, O.E. werian, "to protect, ward off; dam up." If that be correct, weorb would originally have'been applied to a piece of land-with or without a dwelling-protected by a dam or dyke, or possibly a palisade. The transition from this primary sense to that of "farmstead, habitation, estate" is natural and parallel to that observed in the history of the suffix tiun.

The relation between the two German forms werd and werder is the same as between O.E. sal-salor, "hall," sige-sigor, "victory" (Sievers, $\$ 288,289$ ). 


\section{THE PRINCIPAL PERSONAL NAMES IN THE NOTTINGHAMSHIRE PLACE-NAMES}

\section{Anglo-Saxon and Norse Personal Names}

Adda, Adding (Attenborough)

AEzel or AErel (Elton)

A Elf(a) (Elston)

AElfhere (Alverton, Ollerton)

? Alca (Awkley)

Anna (Annesley)

Aslakr (Aslockton)

Babba (Babbington, Babworth)

? Bada (Bathley)

Bagga (Baggalee, Bagthorpe)

Barn (Barnby)

Basing (Basingfield)

Bassa (Basford)

Bealdhere (Balderton)

Becca, Beccing (Beckingham)

Benna, Benning (Bingham)

Beorn (Barnston)

? Bildi (Bilsthorpe)

\& Bilheard (Bilsthorpe)

Billa (Bilborough, Bilby)

? Bliðhere (Blidworth)

*Bodmār or Bodrvine (Bothamsall)

Bondi (Bonbusk)

Bonningas (Bonnington)

*Boōcreulf (Broxtow)

$B r \bar{n}$, Brün (Brinsley)

Bucea (Boughton)

Bütr or Butti (Budby)

? Carl (Carlton, Caythorpe)

Clip (Clipston)

? Cniht (Kneesall, Kneeton)

Codda, Codding, Cotta (Coddington)

Col, Colla, Colling (Car Colston, Collingham, Colston Basset, Colwick) 
*Cortel, Corteling (Costock)

Cotta (Cossal)

Cylfa (Kilvington)

Cynemāer (Kimberley)

Cyneweald (Kinoulton)

*Cyrtel (Kirklington)

Dēorlāf (Darlton)

Dẽorling (Dalington)

Deorna (Danethorpe)

Eada (Edingley?)

Eadbeald or Ealdbeald (Adbolton)

? Eadwacer (Eakring)

Eadrueald (Edwalton)

Eadroine (Edwinstowe, Edingley ?)

Ealda (Awsworth)

Ealhmund (Ompton)

Earne (Arnold)

Eigmund (Egmanton)

${ }^{*}$ Elc (Elkesley)

Eobeorht, *Eoperht (Epperston)

Eofor, Eoforing (Everton, Hoveringham)

Flada (Fledborough)

? Frana (Farnsfield)

Gamal (Gamston)

Gärfrið (Goverton)

Glappa (Glapton)

Golda (Goldthorpe)

Grani (Granby)

Grimr (Grimston)

Grīs (Greasley)

Gunner or Gunnild (Gunthorpe)

Gunnulf (Gonalston)

Gybba, Gyppa (Gibsmere)

Haukr, Hōc (Hawksworth, Hockerton)

Heara (Harworth)

Hiccelingas (Hickling)

Hod or Oddi? (Hodsock)

Hrafn (Rampton, Ranby, Ranskill)

Hrefn (Rempston)

Hrōaldr, Rold (Rolleston)

*Hucca (Hucknall, Huthwaite) 
*Laxa, Leaxa (Laxton)

? Lèofhere (Leverton)

Māna (Manton).

Marwingas (Meering)

Märhere (Mattersey)

* Mamma (Mansfield)

Ordric (Ordsall, Orston)

Osbeorn, $\bar{A}$ sbeorn (Osberton)

* Oskin, $\bar{A}$ sketill (Ossington)

Ōsmund, $\bar{A}$ smund (Osmond thorpe)

Osweard or Ōsweald (Oswardbeck)

? Ragnald, Regnald or Ragnhildr (Ragnall)

Ruddingas (Ruddington)

? Saxi or Seaxa (Saxondale)

Selfa (Selston)

Serlo (Serlby)

Sibbi (Sibthorpe)

Sigeric (Syerston)

Skarf or Sceorf (Scarle, Scarrington?)

? Skaroi, Skardingas (Scarrington?)

Skegge (Skegby)

Skopti (Scofton)

*Snottingas (Nottingham, Sneinton)

Steorra, Styr (Staythorpe, Styrrup)

? Strangzulf (Stragglethorpe)

Tila (Tilne)

Tucca (Tuxford)

bor (Thoresby)

borleifr, borleikr (Tollerton)

porðr, bureð (Torworth)

burferb (Thoroton)

burgeir, burgār (Thurgarton)

burmō̋r (Thrumpton)

purulf (Toton)

? Byri (Treswell)

$\bar{U} f i$ (Owthorpe)

*Wanda (Wansley)

*Wara (Warsop)

Wata (Watnall)

? Wealh (Walesby)

Wealhhere, Walchere (Walkeringham) 


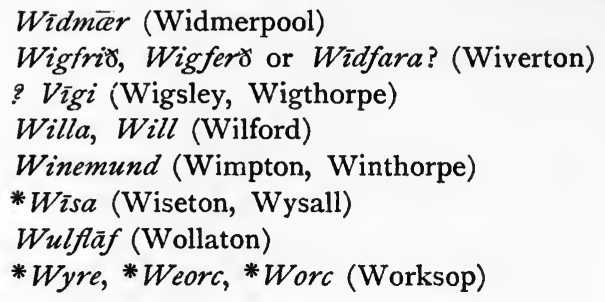

II. Norman-French Personal Names

Bardolf (Stoke Bardolph)

Basset ${ }^{1}$ (Colston Basset)

Butler (Cropwell Butler)

Cantelupe (Watnall Cantelupe)

Joyce, older Jorze (Burton Joyce)

Peverel (Perlethorpe)

Pierrepont (Holme Pierrepont)

Torkard (Hucknall Torkard)

N.B. Several of the above names are explained in the index to the Calendar of Documents Preserved in France, edited by J. Horace Round, 1899.

1 This name was adopted by the family in England, being taken from the Nottinghamshire Hundred name of Bassetlaw (q.v.). 


\section{BIBLIOGRAPHY}

\section{SOURCES OF EARLy Forms of NotTinghamshire Place-NAMes.}

A.S. Chron. Anglo-Saxon Chronicle.

BEDE, Hist. EcCles. Historia Ecclesiastica Gentis Anglorum.

BODL. CH. \& R. Calendar of Charters and Rolls Preserved in the Bodleian Library. Oxford, 1878.

BOR. REC. Records of the Borough of Nottingham. Vol. I. 1882.

CAL. Rot. Chart. Calendarium Rotulorum Chartarum, etc. (Record Office). 1803 .

CAMDEN. Britain, or a Chorographicall Description of the Most flourishing Kingdoms, England, Scotland, and Ireland....Written by William Camden. 1637.

CART. SAX. Cartularium Saxonicum, ed. Birch.

CoD. Dipl. Codex Diplomaticus Ævi Saxonici, ed. Kemble.

D.B. Doomsday Book (in Victoria County History, Vol. I).

Drayton. Drayton's Polyolbion (modernised).

E.E.T. Soc. Early English Text Society, Publications.

F.A. Inquisitions and Assessments relating to Feudal Aids (Record Office). 1899 etc.

For. REC. Forest Records, edited by W. H. Stevenson.

H.R. Rotuli Hundredorum (Record Office). 1812-18.

INDEX. Index to Charters and Rolls in the British Museum. Vol. I. Index Locorum. 1900.

INQ. P.M. Calendar of Inquisitions Post Mortem (Record Office), Vol. I. 1904 ; Vol. II. 1906.

INQ. P.M. c. I500. Abstracts of the Inquisitions P.M. Vol. I. I485-I546 (Thoroton Society, Records Series III). 1905.

LELAND. The Itinerary of John Leland the Antiquary. 2nd edition. Oxford, 1745 .

MaP in Camden. See Camden, above.

MAP I704. Map of Nottinghamshire by R. Morden. 1704.

Mon. ANglic. Dugdale, Monasticon Anglicanum. New edition.

Non. INQ. Nonarum Inquisitiones in Curia Scaccarii. Temp. Regis Edw. III (Record Office). I807.

Notrм. CH. Royal Charters granted to the Burgesses of Nottingham. 1890. 
P.R. The Great Rolls of the Pipe (Pipe Roll Society). I884 etc.

TAX. Eccles. Taxatio Ecclesiastica Angliae et Walliae (Record Office). 1802.

Testa DE N. Testa de Nevil sive Liber Feodorum (Record Office). I807.

THOROTON. Thoroton's History of Nottinghamshire. Republished with Large Additions, by John Throsby. 1797.

VAlor Eccles. Valor Ecclesiasticus. Temp. Regis Hen. VIII. Vol. v (Record Office). 1825-34.

WOLL. MSS. Report on the Manuscripts of Lord Middleton Preserved at Wollaton Hall, ed. W. H. Stevenson (Hist. MSS. Commission). I9II.

\section{Other Books Relating to NotTinghamshire.}

GUILDFORD, E. L. Nottinghamshire (The Little Guides Series).

White, F. History, Directory and Gazetteer of the County, and the

Town and County of the Town of Nottingham. Sheffield, I853.

White, ROBERT. The Dukery Records. I904.

\section{Sources of Personal Names.}

Searle. Onomasticon Anglo-Saxonicum. 1897.

BJÖRKMaN. Nordische Personennamen in England. Halle, I9Io.

RYGH. Gamle Personnavne i norske Stedsnavne. Kristiania, I9OI.

RYGH. Norske Gaardnavne, I. Kristiania, I897.

BARDSLEY. A Dictionary of English and Welsh Surnames. I90I.

Förstemann. Altdeutsches Namenbuch, I. Personennamen. Bonn, I900. WINKLER. Friesche Naamlijst (Onomasticon Frisicum). Leeuwarden, I 898.

WERLE. Die ältesten germanischen Personennamen. Strassburg, 1910.

SocIN. Mittelhochdeutsches Namenbuch. Basel, 1903.

\section{Monographs on Place-Names.}

ALEXANDER. Place-Names of Oxfordshire. I9I2.

Alexander. The Particle -ing in Place-Names. (Essays and Studies by Members of the English Association, Vol. II.)

Alexander. The Genitive Suffix in the First Element of English PlaceNames. (Modern Language Review, 1911.)

Bradley, Henry. English Place-Names. (Essays and Studies by Members of the English Association, Vol. I.)

Duignan. Place-Names of Staffordshire ;-Warwickshire ;-Worcestershire.

Förstemann. Altdeutsches Namenbuch, II. Ortsnamen. Nordhausen, 1872.

Jellinghaus. Englische und niederdeutsche Ortsnamen. (Anglia, xx. pp. 257-334.)

MacCluRe. British Place-Names in their Historical Setting. I9lo. 
MIDDENDORF. Altenglisches Flurnamenbuch. Halle, 1902.

Miller. Place-Names in the Old English Bede. Strassburg, 1896.

Moorman. Place-Names of the West Riding of Yorkshire. (Transactions of the Thoresby Society.) Leeds, 1910.

NAPIER AND Stevenson. The Crawford Collection of Charters.' 1895.

SCHRÖDER, EDWARD. Über Ortsnamenforschung. (Harzverein für Geschichte und Altertumskunde.) Wernigerode, 1908.

Sephton. Handbook of Lancashire Place-Names. Liverpool, I9r3.

SkEAT. Place-Names of Bedfordshire ;-Berkshire ;-Cambridgeshire ;Hertfordshire ;-Huntingdonshire.

STURMFEls. Die Ortsnamen Hessens. Leipzig, rgro.

TAYLOR. Words and Places.-English Village Names. (Reprinted in Everyman's Library.)

WYLD AND HIRST. Place-Names of Lancashire. I9I I.

ZACHRISSON. A Contribution to the Study of Anglo-Norman Influence on English Place-Names. Lund, 1909.

\section{General Books of Reference on Grammar, Etymology, AND PHONOLOGY.}

Bosworth-Toller. An Anglo-Saxon Dictionary.

BÜLBRING. Altenglisches Elementarbuch, I. Heidelberg, 1902. HIRT. Weygandt's Deutsches Wörterbuch.

HORN. Historische Neuenglische Grammatik, I. Strassburg, 1908.

KLUGE. Etymologisches Wörterbuch der deutschen Sprache.

MORSBACH. Mittelenglische Grammatik, I.

Murray, Bradley, aNd Craigie. New English Dictionary [N.E.D.].

Sievers. Angelsächsische Grammatik. 3rd edition. Halle, I898.

SkeAT. Etymological Dictionary of the English Language. 4th edition.

STOLzE. Zur Lautlehre der altenglischen Ortsnamen im Domesday Book.

Berlin, 1902.

Stratmann-Bradley. Middle English Dictionary. I89I.

SwEET. Student's Dictionary of Anglo-Saxon. 1897.

SwEET. New English Grammar, Logical and Historical. 1900.

VigfuSSON-CleAsby. Icelandic Dictionary. I874. [Vigf.]

WRIGHT. English Dialect Dictionary [Dial. Dict.].

WRIGHT. English Dialect Grammar [Dial. Gramm.]. 


THIS BOOK IS DUE ON THE LAST DATE STAMPED BELOW

\section{AN INITIAL FINE OF 25 CENTS} WILL BE ASSESSED FOR FAILURE TO RETURN THIS BOOK ON THE DATE DUE. THE PENALTY WILL INCREASE TO 50 CENTS ON THE FOURTH DAY AND TO \$1.00 ON THE SEVENTH DAY OVERDUE.

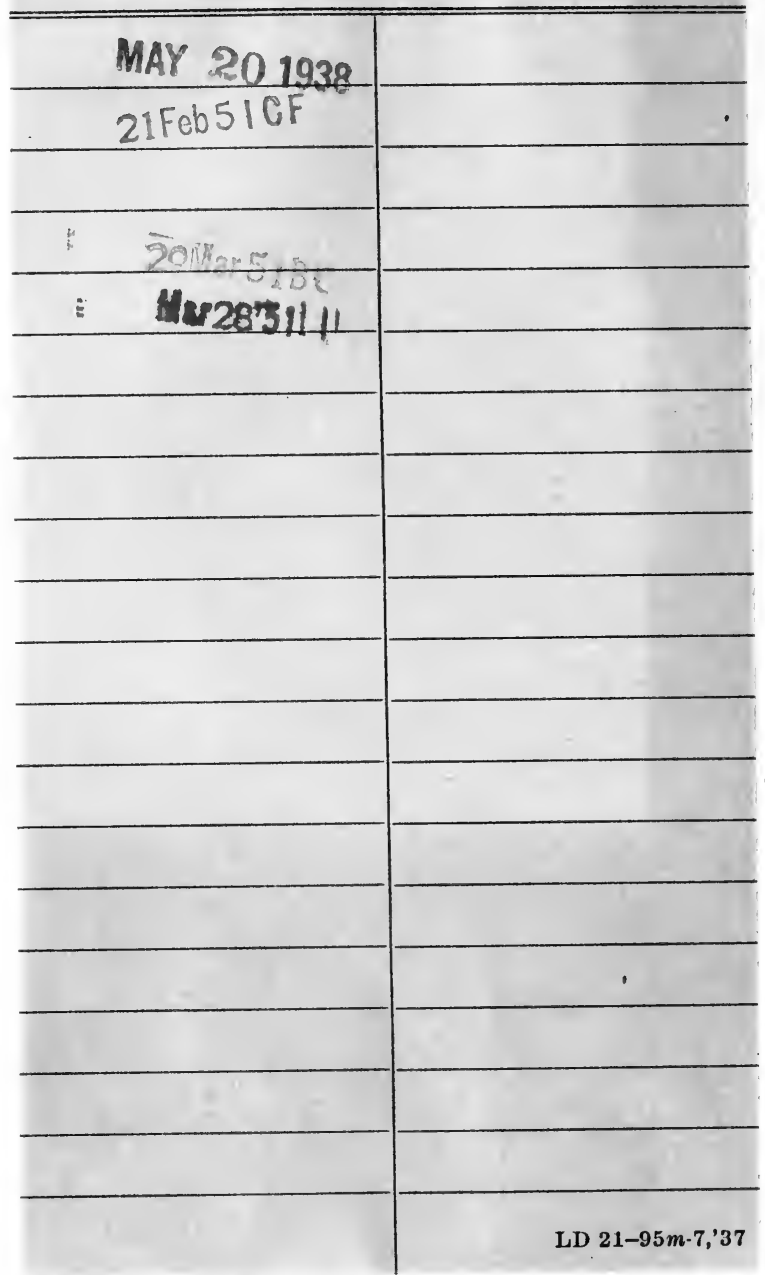




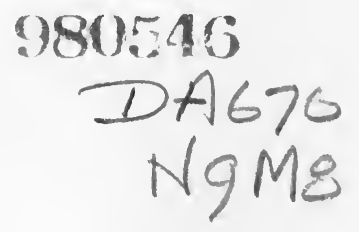

THE UNIVERSITY OF CALIFORNIA LIBRARY 
